University of Tennessee Health Science Center

UTHSC Digital Commons

\title{
Forecasting the Essential Chemotherapy Needed for Treatment of Children with Acute Lymphoblastic Leukemia in Low- and Middle- Income Countries
}

\author{
Brian T. Lewis \\ University of Tennessee Health Science Center
}

Follow this and additional works at: https://dc.uthsc.edu/dissertations

Part of the Diseases Commons, Health and Medical Administration Commons, and the Pediatric Nursing Commons

\section{Recommended Citation}

Lewis, Brian T. (http://orcid.org/0000-0002-3747-2517), "Forecasting the Essential Chemotherapy Needed for Treatment of Children with Acute Lymphoblastic Leukemia in Low- and Middle-Income Countries" (2020). Theses and Dissertations (ETD). Paper 520. http://dx.doi.org/10.21007/etd.cghs.2020.0505.

This Dissertation is brought to you for free and open access by the College of Graduate Health Sciences at UTHSC Digital Commons. It has been accepted for inclusion in Theses and Dissertations (ETD) by an authorized administrator of UTHSC Digital Commons. For more information, please contact jwelch30@uthsc.edu. 


\title{
Forecasting the Essential Chemotherapy Needed for Treatment of Children with Acute Lymphoblastic Leukemia in Low- and Middle-Income Countries
}

\begin{abstract}
Acute lymphoblastic leukemia (ALL) is the most common pediatric cancer, with contemporary therapy resulting in a $90 \%$ survival in high-income countries (HIC). However, an estimated $89 \%$ of the world's children live in low- and middle-income countries (LMIC) where survival is much lower. Lack of access to essential chemotherapy contributes significantly to the decreased survival rates for LMIC, and inaccurate forecasting of chemotherapy needed may lead to stockouts or oversupply. This chapter describes a simple forecasting system with population and patient-based multipliers for each drug used in the treatment of pediatric ALL, thus estimating the essential chemotherapy quantities needed for a single patient, facility, region, or country.

We described a forecasting model for estimating essential chemotherapy in the treatment of childhood ALL to multipliers. Multipliers were obtained from a reference population of 10 million children evenly distributed (2.5 million each) across four age cohorts at 5-year intervals (0-4, 5-9, 10-14, and 15-19 years). The forecasting model and multipliers were applied to 171 countries with age-specific population data available in the United Nations 2017 World Populations Prospects. Results from the forecasting model and multipliers were compared to determine differences for each country and for countries with extreme population distributions across the pediatric age range. The multipliers produced results no greater than $15 \%$ of those obtained using the forecasting model.
\end{abstract}

Multipliers allow healthcare providers, cancer centers, hospitals, countries, and drug manufacturers to accurately estimate the essential chemotherapy needs for a patient, facility, region, or country. This practical tool can be applied to other cancer diagnoses and treatment protocols.

\section{Document Type}

Dissertation

\section{Degree Name}

Doctor of Philosophy (PhD)

\section{Program}

Nursing Science

\section{Research Advisor}

Scott C. Howard

\section{Keywords}

Chemotherapy, Forecasting, Incidence, Income, LMIC, Multipliers

\section{Subject Categories}

Diseases | Health and Medical Administration | Medicine and Health Sciences | Nursing | Pediatric Nursing 
UNIVERSITY OF TENNESSEE HEALTH SCIENCE CENTER

DOCTOR OF PHILOSOPHY DiSSERTATION

\section{Forecasting the Essential Chemotherapy Needed for Treatment of Children with Acute Lymphoblastic Leukemia in Low- and Middle- Income Countries}

Author:

Brian T, Lewis
Advisor:

Scott C. Howard, MD, MSc

A Dissertation Presented for The Graduate Studies Council of

The University of Tennessee Health Science Center in Partial Fulfillment of the Requirements for the

Doctor of Philosophy degree from

The University of Tennessee

in

Nursing Science

College of Graduate Health Sciences

May 2020 
Copyright (C) 2020 by Brian T. Lewis.

All rights reserved. 


\section{DEDICATION}

I dedicate this dissertation to my family: my beloved wife, Yvette; my precious children, Jackson and Edison; my ever-loving parents, Richard and Shirley; and my supportive brother and sister, Alan and Monica. Without your love, support, and prayers, this would never have been possible. 


\section{ACKNOWLEDGEMENTS}

It is a pleasure to acknowledge Dr. Scott Howard, my dissertation committee chair. I will always be grateful for the time you invested in me. Your work for children globally is inspiring and has changed and improved many lives, including mine.

I would also like to thank and acknowledge all of my committee members:

Dr Xueyuan Cao, thank you for your tireless work in helping me understand the appropriate statistical approach to this process;

Dr. Donna Hathaway, thank you for help and encouragement in identifying the variables in the forecasting model;

Dr. Belinda Mandrell, thank you for your patience and diligence in ensuring clear, concise, and accurate manuscripts;

Dr. Mona Wicks, thank you for ensuring I conceptually and theoretically understood and could describe my work;

Additionally, I would like to thank Curtis Roby for his assistance with the formatting and electronic design of this dissertation.

I would also like to recognize the time and encouragement that Dr. Carolyn Graff, Dr. Sarah Jane Rhoads, Dr. Elizabeth A. "Betsy" Tolley, Eric Long, and Kimberly Gawart have provided to me during this process. 


\begin{abstract}
Acute lymphoblastic leukemia (ALL) is the most common pediatric cancer, with contemporary therapy resulting in a $90 \%$ survival in high-income countries (HIC). However, an estimated $89 \%$ of the world's children live in low- and middle-income countries (LMIC) where survival is much lower. Lack of access to essential chemotherapy contributes significantly to the decreased survival rates for LMIC, and inaccurate forecasting of chemotherapy needed may lead to stockouts or oversupply. This chapter describes a simple forecasting system with population and patient-based multipliers for each drug used in the treatment of pediatric ALL, thus estimating the essential chemotherapy quantities needed for a single patient, facility, region, or country.

We described a forecasting model for estimating essential chemotherapy in the treatment of childhood ALL to multipliers. Multipliers were obtained from a reference population of 10 million children evenly distributed (2.5 million each) across four age cohorts at 5-year intervals (0-4, 5-9, 10-14, and 15-19 years). The forecasting model and multipliers were applied to 171 countries with age-specific population data available in the United Nations 2017 World Populations Prospects. Results from the forecasting model and multipliers were compared to determine differences for each country and for countries with extreme population distributions across the pediatric age range. The multipliers produced results no greater than $15 \%$ of those obtained using the forecasting model.
\end{abstract}

Multipliers allow healthcare providers, cancer centers, hospitals, countries, and drug manufacturers to accurately estimate the essential chemotherapy needs for a patient, facility, region, or country. This practical tool can be applied to other cancer diagnoses and treatment protocols. 


\section{TABLE OF CONTENTS}

CHAPTER 1. INTRODUCTION .....................................................................................1

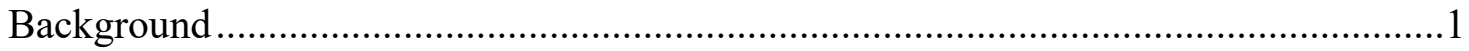

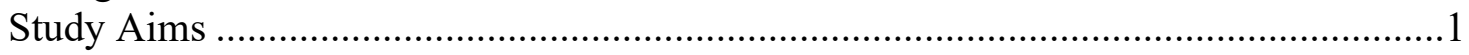

\section{CHAPTER 2. FORECASTING THE NEED FOR ESSENTIAL CHEMOTHERAPY FOR CHILDREN WITH CANCER IN LOW-AND MIDDLE-INCOME COUNTRIES: MERCAPTOPURINE IN THE}

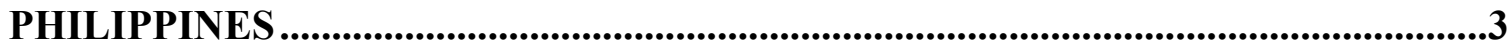

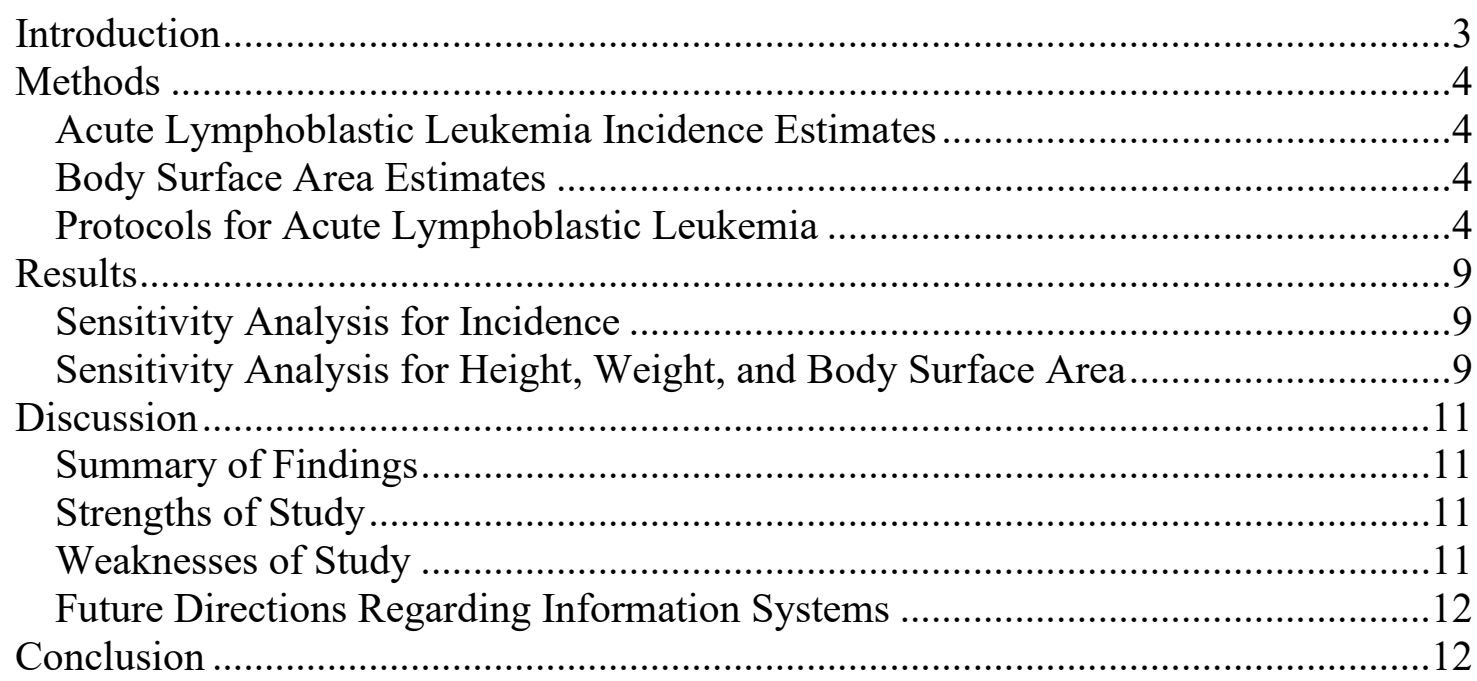

CHAPTER 3. FORECASTING THE ESSENTIAL CHEMOTHERAPY

NEEDED FOR TREATMENT OF CHILDREN WITH ACUTE

LYMPHOBLASTIC LEUKEMIA IN LOW- AND MIDDLE-INCOME

COUNTRIES: TANZANIA, HONDURAS, AND VENEZUELA............................13

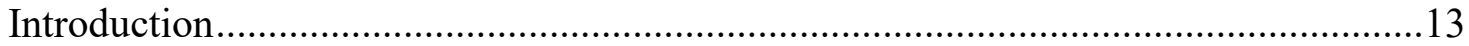

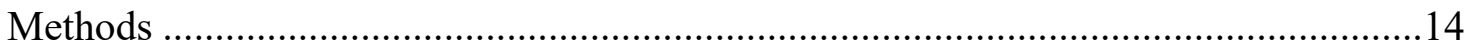

Protocols for Acute Lymphoblastic Leukemia ......................................................... 14

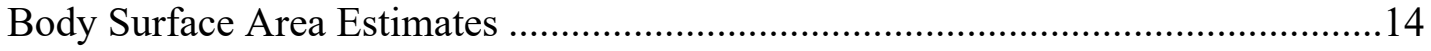

Acute Lymphoblastic Leukemia Incidence Estimates .........................................15

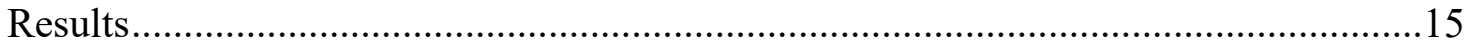

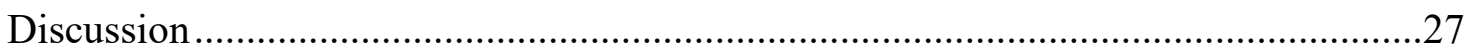

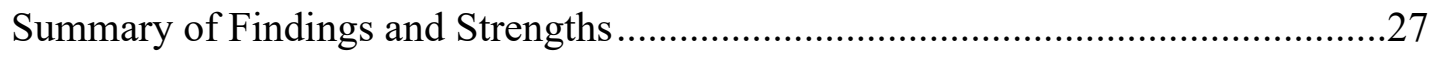

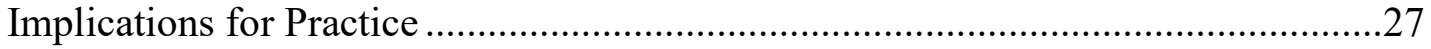

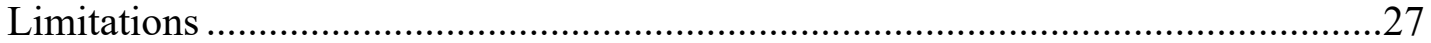

Future Directions - ALL Essential Chemotherapy Multipliers ..............................28

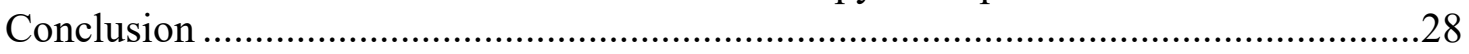




\section{CHAPTER 4. UTILIZING MULTIPLIERS TO FORECAST ESSENTIAL CHEMOTHERAPY FOR TREATMENT OF ACUTE LYMPHOBLASTIC LEUKEMIA IN CHILDREN AND ADOLESCENTS RESIDING IN LOW- AND MIDDLE-INCOME COUNTRIES ...............................................................29}

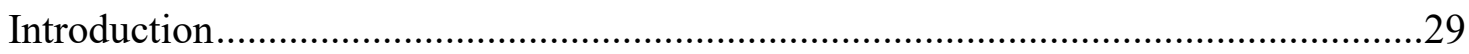

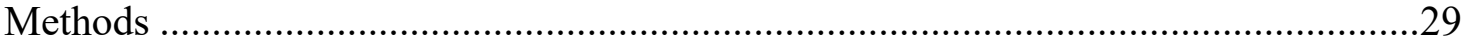

Multipliers and Comparisons to Forecast Model ................................................29

Comparison of Outliers of Extreme Population Distributions .................................30

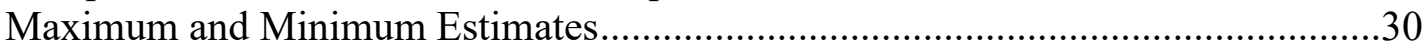

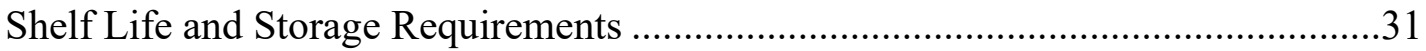

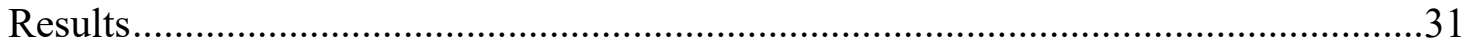

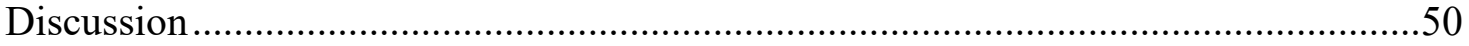

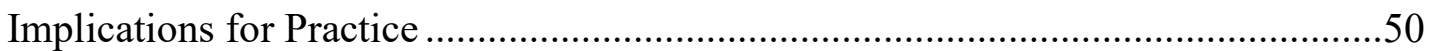

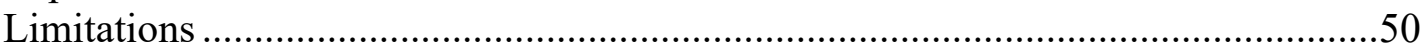

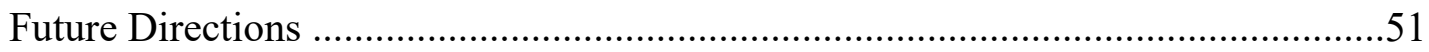

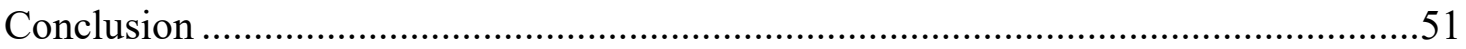

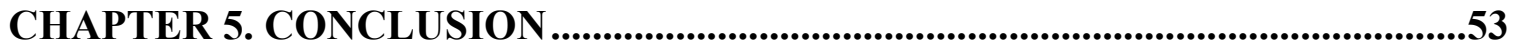

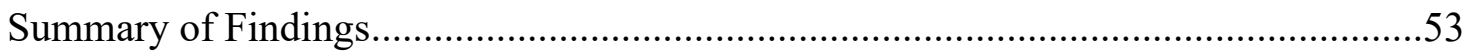

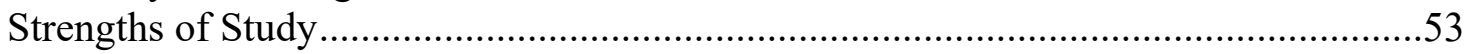

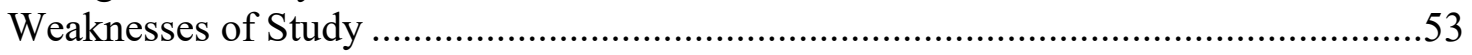

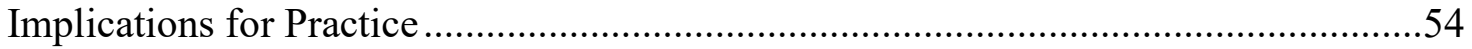

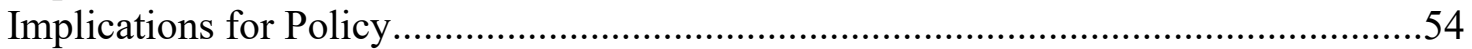

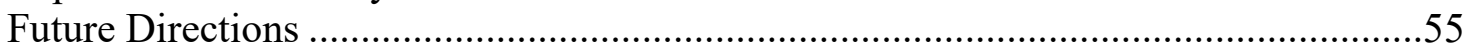

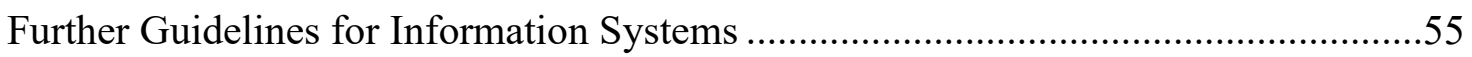

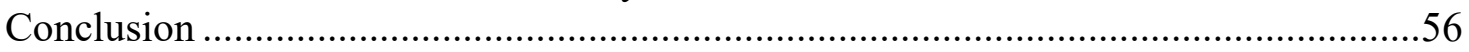

LIST OF REFERENCES ...................................................................................................57

APPENDIX. STANDARD POPULATION-BASED MULTIPLIER FOR EACH

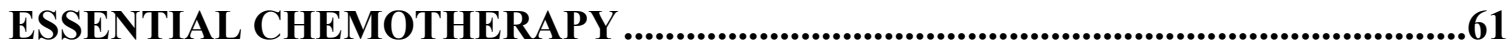

VITA 


\section{LIST OF TABLES}

Table 2-1. Estimated numbers of children who develop acute lymphoblastic leukemia in the Philippines

Table 2-2. Mercaptopurine needed in the Philippines each year, assuming that all centers use setting 2 regimens......

Table 2-3. Mercaptopurine needed at 100\% Setting 1 centers

Table 2-4. Mercaptopurine needed to cover $100 \%$ of children in the Philippines using the Setting 3 regimens

Table 2-5. Demographic information about children with acute lymphoblastic leukemia in the Philippines

Table 3-1. Number of children at each age group and expected cases of acute lymphoblastic leukemia in four countries

Table 3-2. Forecasted quantities of each essential medication required to deliver the SIOP Adapted ALL Regimen Level 1 without cranial radiation in three countries

Table 3-3. Forecasted quantities of each essential medication required to deliver the SIOP Adapted ALL Regimen Level 1 with cranial radiation in three countries

Table 3-4. Forecasted quantities of each essential medication required to deliver the SIOP Adapted ALL Regimen Level 2

Table 3-5. Forecasted quantities of each essential medication required to deliver the SIOP Adapted ALL Regimen Level 3

Table 3-6. Doses of essential medication required per SIOP Adapted ALL Protocol

Regimens

Table 4-1. Difference between the multipliers and forecasting model for International Society of Paediatric Oncology Adapted Acute Lymphoblastic Leukemia Regimen Level 1 without cranial radiation in selected countries that represent extremes of age distribution

Table 4-2. Difference between the multipliers and forecasting model for International Society of Paediatric Oncology Adapted Acute Lymphoblastic Leukemia Regimen Level 1 with cranial radiation in selected countries that represent extremes of age distribution..... 
Table 4-3. Difference between the multipliers and forecasting model for International Society of Paediatric Oncology Adapted Acute Lymphoblastic Leukemia Regimen Level 2 in selected countries that represent extremes of age distribution

Table 4-4. Difference between the multipliers and forecasting model for International Society of Paediatric Oncology Adapted Acute Lymphoblastic Leukemia Regimen Level 3 in selected countries that represent extremes of age distribution

Table 4-5. Patient and population multipliers for International Society of Paediatric Oncology Adapted Acute Lymphoblastic Leukemia Regimen Level 1 without cranial radiation

Table 4-6. Patient and population multipliers for International Society of Paediatric Oncology Adapted Acute Lymphoblastic Leukemia Regimen Level 1 with cranial radiation

Table 4-7. Patient and population multipliers for International Society of Paediatric Oncology Adapted Acute Lymphoblastic Leukemia Regimen Level 2 with cranial radiation

Table 4-8. Patient and population multipliers for International Society of Paediatric Oncology Adapted Acute Lymphoblastic Leukemia Regimen Level 3.......46

Table 4-9. Shelf life and storage requirements for medications used to treat acute lymphoblastic leukemia with the International Society of Paediatric Oncology Regimens

Table A-1. Standard population-based multiplier for SIOP Adapted ALL Regimen Level 1 without cranial radiation in three countries. 


\section{LIST OF ABBREVIATIONS}

$\begin{array}{ll}\text { ALL } & \text { Acute lymphoblastic leukemia } \\ \text { BFM } & \text { Berlin-Frankfurt-Munster regimen } \\ \text { CDC } & \text { Centers for Disease Control and Prevention } \\ \text { CRT } & \text { Cranial irradiation } \\ \text { CSR } & \text { Cancer Statistics Review } \\ \text { EMA } & \text { European Medicines Agency } \\ \text { EML } & \text { Essential medicines list } \\ \text { FDA } & \text { Food and Drug Administration } \\ \text { HIC } & \text { High-income countries } \\ \text { LMIC } & \text { Low- and middle-income countries } \\ \text { MG } & \text { Milligrams } \\ \text { MHRA } & \text { Medicines and Healthcare products Regulatory Agency } \\ \text { NCI } & \text { National Cancer Institute } \\ \text { NIH } & \text { National Institutes of Health } \\ \text { PODC } & \text { Pediatric Oncology in Developing Countries } \\ \text { SEER } & \text { Surveillance, Epidemiology, and End Results } \\ \text { UMIC } & \text { Upper-middle income countries } \\ \text { WHO } & \text { World Health Organization } \\ \text { 6MP } & \text { Mercaptopurine }\end{array}$




\section{CHAPTER 1. INTRODUCTION}

\section{Background}

Worldwide, each year approximately 429,000 children between the ages of 0 to 19 will develop cancer (Lam, Howard, Bouffet, \& Pritchard-Jones, 2019). The 5-year survival rate for the $10 \%$ (or 42,900 ) of these children who live in high-income countries (HIC) exceeds $80 \%$ (Allemani et al., 2018; Bhakta, Martiniuk, Gupta, \& Howard, 2013; Howard et al., 2008; Pritchard-Jones et al., 2013; Rodriguez-Galindo et al., 2015). In contrast, the 5-year survival rate for the remaining $90 \%$ (or 386,100 ) children who live in low- and middle-income countries (LMIC) is less than 30\% in many places (Lam et al., 2019).

The most common cancer afflicting children worldwide is acute lymphoblastic leukemia (ALL), which accounts for $25 \%$ of all childhood cancers (Katz, Chia, Schoonen, \& Kelsh, 2015). Fortunately, effective treatment is available, and in HIC, approximately $90 \%$ of children with ALL will survive with minimal long-term disability (Bhakta et al., 2013). In LMIC, however, cure rates for ALL are significantly lower than those in HIC (Allemani et al., 2015; Bhakta et al., 2013; Cooper \& Brown, 2015; Jabbour, Pui, \& Kantarjian, 2018; Jaime-Perez et al., 2016; Magrath et al., 2013; Pribnow, Ortiz, Baez, Mendieta, \& Luna-Fineman, 2017; Redaniel et al., 2010).

Causes of preventable treatment failure in LMIC include lack of diagnosis, incorrect or delayed diagnosis, abandonment, treatment refusal, excessively high rates of toxic death, and relapse (Howard et al., 2017). Lack of access to essential chemotherapy is an important contributor to the disparate survival rates for LMIC that improve when issues impeding access are addressed (Denburg, Knaul, Atun, Frazier, \& Barr, 2014; Lam et al., 2019; Moye-Holz, van Dijk, Reijneveld, \& Hogerzeil, 2017; Simonyan et al., 2019). A key contributor to assuring access to required medication in LMIC lies in the accurate forecasting of demand for essential chemotherapy (Pisa \& McCurdy, 2019). However, rarely is disease incidence used to calculate the demand for essential chemotherapy (Denburg et al., 2014). Data indicate that without utilizing disease incidence to inform inventory levels and buying patterns, minimal improvements in survival rates will occur (Denburg et al., 2014). The overall goal of the series of studies reported here was to develop a forecasting model and describe patient and population multipliers that estimate the annual essential chemotherapy required to treat ALL for a country based upon the estimated yearly incidence of ALL for that country.

\section{Study Aims}

The aim of the first study was to develop a model to forecast the required mercaptopurine (one of several essential chemotherapeutics needed to treat ALL) to treat every child with ALL in an LMIC annually, using the Philippines as an example. Readily available data sources were utilized to develop the forecasting model. Surveillance, Epidemiology, and End Results data (SEER) were utilized to estimate the incidence rate of ALL. The SEER Cancer Statistics Review 1975 - 2016 was chosen for 3 reasons. First, ALL incidence peaks in children at 2 to 3 years of 
age, but the incidence does vary by age, each year, and SEER provides yearly incidence rates, in 1-year intervals, for children up to the age of 19 (National Institutes of Health, 2010). Second, SEER data were analyzed and refreshed yearly if needed. Third, SEER data were believed to be appropriate for LMIC since variation in international incidence of ALL is thought to be minimal (Katz et al., 2015; Lam et al., 2019). The study population reflected the 2015 Philippines Census Data that provided male and female children and adolescents in 1-year intervals up to the age of 19. For body surface area, the World Health Organization (WHO) and Centers for Disease Control and Prevention (CDC) growth charts provided length or height and weight for males and females to calculate body surface area at 1-year intervals for children up to 19 years of age. Both are based on rigorous study designs for growth assessment, and these standards and measurements are consistently reviewed. Risk-group categorization was needed since drug utilization and dosing was based upon low-, medium-, and high-risk categorization. The BerlinFrankfurt-Munster (BFM) protocol studied from 1981 to 2000, with nearly 7,000 children with ALL, was used to estimate the percentages of patients expected to fall into each risk stratum. The International Society of Pediatric Oncology (SIOP) ALL Adapted Regimens, adapted for LMIC, was used for the forecasting model. The SIOP ALL Adapted Regimens were developed with consideration of the resources of cancer centers within LMIC (Hunger, Sung, \& Howard, 2009).

The aim of the second study was to expand the forecasting model to include the quantity of every essential chemotherapy needed to treat each child and adolescent diagnosed with ALL. The forecasting model was applied to three levels of emerging countries: Tanzania for lowincome; Honduras for lower-middle-income; and Venezuela for upper-middle-income (World Bank, 2018). Ensuring timely, accurate, and consistent population data across the three countries' census processes could not be achieved. Therefore, the United Nations (UN) World Population Prospects was utilized to provide male and female children and adolescent data in 1year intervals up to the age of 19; these population projections utilized all available data on population size, including 1,700 censuses (United Nations, 2019). It also included mortality, fertility, and international migration projections for all regions and countries which comprise the population of the world. The UN World Population projections are refreshed every year.

The aim of the third study was to describe multipliers that achieve results similar to those of the forecasting model but with greatly simplified inputs that enable rapid estimation of the essential chemotherapy needed to treat ALL for any individual patient, cancer treatment facility, country, or region. The patient multiplier was a given number that can be multiplied by any number of children 0-19 years of age with ALL to estimate their needed essential chemotherapy for treatment. The population multiplier was a given number that could be multiplied by a population of children 0-19 years of age to estimate the needed essential chemotherapy for the projected incidence of pediatric ALL. The forecasting multipliers were developed by a hypothetical population of 10,000,000 children evenly distributed ( 2.5 million each) across four 5-year interval age cohorts $(0-4,5-9,10-14$, and 15-19 years) calculated by the forecasting model projection. Patient multipliers were calculated by dividing the total chemotherapy dosage required to treat the projected ALL incidence by population (354). Population multipliers were calculated by dividing the total milligrams $(\mathrm{mg})$ of the given chemotherapy required to treat the population by the population $(10,000,000)$. 


\title{
CHAPTER 2. FORECASTING THE NEED FOR ESSENTIAL CHEMOTHERAPY FOR CHILDREN WITH CANCER IN LOW- AND MIDDLE-INCOME COUNTRIES: MERCAPTOPURINE IN THE PHILIPPINES
}

\begin{abstract}
Introduction
Event-free survival for children and adolescents diagnosed with acute lymphoblastic leukemia (ALL) exceeds $85 \%$ in high-income countries (HIC); however, event-free survival is much lower in LMIC (Allemani et al., 2015; Bhakta et al., 2013; Jabbour et al., 2018; Jeha et al., 2019; Magrath et al., 2013; Pribnow et al., 2017; Redaniel et al., 2010). Treatment failure in LMIC is multifactorial and may include lack of diagnosis, delayed or incorrect diagnosis, refusal, abandonment, toxic death, and preventable relapse (Howard et al., 2017). One cause of preventable relapse is lack of access to essential chemotherapy, which often occurs as a result of systemic factors including national or regional drug shortages and stock-outs (Ruff, Al-Sukhun, Blanchard, \& Shulman, 2016). Mercaptopurine (6MP) has been an essential drug in the treatment of ALL for over 50 years and is considered an essential cancer medication by the World Health Organization (WHO) (Barr \& Robertson, 2016; Gaynon, 2017; Singh, Bhatia, Khera, \& Trehan, 2017; Smid, Karas-Kuzelicki, Jazbec, \& Mlinaric-Rascan, 2016).
\end{abstract}

The International Pediatric Oncology Society (SIOP) Pediatric Oncology in Developing Countries (PODC) Essential Medicines Working Group has identified 6MP access as a significant challenge for LMIC, especially after the 2017 prolonged national shortage in the Philippines (Mehta, Wiernikowski, Petrilli, Barr, \& Working Group on Essential Medicines of the Pediatric Oncology in Developing Countries committee of SIOP, 2013). Drug shortages are multifactorial, with production being one common factor resulting from a drug company no longer producing the drug or manufacturing facilities that may close due to unforeseen circumstances. Complex regulatory procedures require substantial time and funding for drug manufacturing replacements, and mechanisms to accrue emergency supplies can be difficult to initiate (Allemani et al., 2015). Compounding these difficulties, low-standing inventories and complex in-country supply chains make national or sub-national shortages likely during the transition to a new supplier. Forecasting the maximum quantity of monthly chemotherapy requirements at the national level would allow the country to maintain several months of inventory. This is particularly true for inexpensive generic drugs like 6MP which have a long shelf-life and no comparable substitutes.

Herein, we describe a model that utilizes the age distribution of children in the Philippines, age-standardized incidence of childhood ALL, and mean body surface area by age based on height and weight tables to predict the quantity of 6MP needed annually to treat every child and adolescent diagnosed with ALL in the Philippines. Such forecasting assures adequate monthly supplies and inventory at the national level to withstand shortages due to the potential loss of a supplier and other factors. This model is practical and can be applied regardless of the cancer type, treatment protocol, or drugs of interest. 


\section{Methods}

\section{Acute Lymphoblastic Leukemia Incidence Estimates}

Philippines 2015 census data released Friday, June 30, 2017, were used to determine the male and female population in one-year intervals for children and adolescents through 19 years of age (Philippine Statistics Authority, 2017). The National Institutes of Health (NIH); National Cancer Institute (NCI); and Surveillance, Epidemiology, and End Results (SEER) Cancer Statistics Review (CSR) 1975-2010 data were used to determine the incidence of ALL in oneyear intervals by multiplying the CSR incidence rate per 100,000 per year by the population of children of that age from the Philippines census data (National Institutes of Health, 2010).

\section{Body Surface Area Estimates}

The WHO and CDC growth charts provided length/height and weight for males and females to calculate body surface area at 1-year intervals for patients 0 -19 years of age (Centers for Disease Control and Prevention, 2010). WHO length and weight charts were used for males and females from age 0-24 months of age, while the CDC growth charts were used for males and females 3-19 years of age. WHO length and growth charts were used for infants and toddlers 024 months, as these growth charts provide normative standards for breastfed children and are more consistent with the physiological description of growth in infancy. WHO growth charts do not provide data for children over 5 years old; however, the methods for CDC and WHO growth charts are similar for children 2-5 years of age and both are based on rigorous study designs for growth assessment (Centers for Disease Control and Prevention, 2010).

\section{Protocols for Acute Lymphoblastic Leukemia}

The SIOP Adapted ALL Regimens for use in LMIC is utilized in the Philippines and likewise was used as a model protocol in our forecasting model (Hunger et al., 2009). The SIOP Adapted ALL Regimens includes 3 risk strata and 3 types of oncology centers, which have been described elsewhere to identify the optimal regimen for each patient based upon leukemia risk features and resources available at the treatment center (Howard et al., 2017). Centers were defined by supportive care resources, with setting 1 centers having limited supportive care; therefore, the use of intense chemotherapy regimens is associated with an unacceptably high rate of toxic death; setting 2 centers have intermediate supportive care; and setting 3 centers are comparable to centers in HIC. The initial forecast calculation was based on setting 2 regimens, which are comparable to most centers in the Philippines. The estimated 6MP quantity was also calculated for setting 1 and 3 centers to determine if this would significantly change the amount of 6MP needed. The detailed 6MP quantity according to center is detailed in Tables 2-1 to 2-4.

The SIOP Adapted ALL Regimens stratify risk based on age, white blood cell count, central nervous system status at diagnosis, and early response to treatment. The three risk categories are lower risk, higher risk, and very high risk. 
Table 2-1. Estimated numbers of children who develop acute lymphoblastic leukemia in the Philippines

\begin{tabular}{|c|c|c|c|c|c|c|c|}
\hline \multirow[b]{2}{*}{ Age } & \multicolumn{3}{|c|}{ Children by year of age } & \multicolumn{4}{|c|}{ Cases of childhood ALL } \\
\hline & Both sexes & Female & Male & $\begin{array}{c}\text { ALL } \\
\text { incidence* }\end{array}$ & $\begin{array}{l}\text { Both } \\
\text { sexes }\end{array}$ & Female & Male \\
\hline 0 & $2,075,441$ & $1,002,348$ & $1,073,093$ & 2 & 42 & 20 & 21 \\
\hline 1 & $2,090,348$ & $1,011,207$ & $1,079,141$ & 4.6 & 96 & 47 & 50 \\
\hline 2 & $2,190,994$ & $1,059,470$ & $1,131,524$ & 9.8 & 215 & 104 & 111 \\
\hline 3 & $2,234,812$ & $1,079,682$ & $1,155,130$ & 9.5 & 212 & 103 & 110 \\
\hline 4 & $2,224,403$ & $1,074,395$ & $1,150,008$ & 7.6 & 169 & 82 & 87 \\
\hline 5 & $2,180,700$ & $1,053,790$ & $1,126,910$ & 4.6 & 100 & 48 & 52 \\
\hline 6 & $2,172,796$ & $1,052,777$ & $1,120,019$ & 4.4 & 96 & 46 & 49 \\
\hline 7 & $2,236,650$ & $1,080,921$ & $1,155,729$ & 3.2 & 72 & 35 & 37 \\
\hline 8 & $2,139,569$ & $1,035,343$ & $1,104,226$ & 2.6 & 56 & 27 & 29 \\
\hline 9 & $2,109,160$ & $1,021,322$ & $1,087,838$ & 2.7 & 57 & 28 & 29 \\
\hline 10 & $2,191,716$ & $1,055,585$ & $1,136,131$ & 2.4 & 53 & 25 & 27 \\
\hline 11 & $2,084,417$ & $1,011,595$ & $1,072,822$ & 2.3 & 48 & 23 & 25 \\
\hline 12 & $2,092,242$ & $1,018,281$ & $1,073,961$ & 1.9 & 40 & 19 & 20 \\
\hline 13 & $2,026,422$ & 986,865 & $1,039,557$ & 2.1 & 43 & 21 & 22 \\
\hline 14 & $2,085,615$ & $1,010,573$ & $1,075,042$ & 2.2 & 46 & 22 & 24 \\
\hline 15 & $2,198,355$ & $1,062,568$ & $1,135,787$ & 2 & 44 & 21 & 23 \\
\hline 16 & $1,956,206$ & 955,414 & $1,000,792$ & 2.2 & 43 & 21 & 22 \\
\hline 17 & $2,020,544$ & 986,426 & $1,034,118$ & 1.6 & 32 & 16 & 17 \\
\hline 18 & $2,015,993$ & 996,061 & $1,019,932$ & 1.7 & 34 & 17 & 17 \\
\hline 19 & $1,929,214$ & 955,586 & 973,628 & 1.4 & 27 & 13 & 14 \\
\hline Total & $42,255,597$ & $20,510,209$ & $21,745,388$ & & 1,523 & 738 & 785 \\
\hline
\end{tabular}

Notes: ALL - Acute lymphoblastic leukemia. Population data retrieved from Philippine Statistics Authority. (2017). Philippine Population Surpassed the 100 Million Mark (Results from the 2015 Census of Population). Retrieved from https://www.psa.gov.ph/content/philippine-populationsurpassed-100-million-mark-results-2015-census-population. ALL rate data retrieved National Institutes of Health. (2010). National Institutes of Health National Cancer Institute Surveillance, Epidemiology, and End Results. Retrieved from https://seer.cancer.gov/archive/csr/1975 2010/browse_csr.php?sectionSEL=28\&pageSEL=sect 28 table. 13. html.

*This number represents ALL incidence per million children per year. 
Table 2-2. Mercaptopurine needed in the Philippines each year, assuming that all centers use setting 2 regimens

\begin{tabular}{lccc}
\hline Age & $\begin{array}{c}\text { Total mg of } \\
\text { 6MP }\end{array}$ & $\begin{array}{c}\text { Approximate } \\
\text { 50mg tablets }\end{array}$ & $\begin{array}{c}\text { Approximate bottles } \\
\text { of 30 tablets/50mg }\end{array}$ \\
\hline 0 & 913,345 & 18,267 & 609 \\
1 & $2,477,153$ & 49,543 & 1,651 \\
2 & $6,724,258$ & 134,485 & 4,483 \\
3 & $7,560,640$ & 151,213 & 5,040 \\
4 & $6,651,099$ & 133,022 & 4,434 \\
5 & $4,341,345$ & 86,827 & 2,894 \\
6 & $4,526,172$ & 90,523 & 3,017 \\
7 & $3,686,621$ & 73,732 & 2,458 \\
8 & $3,105,628$ & 62,113 & 2,070 \\
9 & $3,439,300$ & 68,786 & 2,293 \\
10 & $3,435,135$ & 68,703 & 2,290 \\
11 & $3,389,262$ & 67,785 & 2,260 \\
12 & $3,043,988$ & 60,880 & 2,029 \\
13 & $3,512,450$ & 70,249 & 2,342 \\
14 & $4,039,293$ & 80,786 & 2,693 \\
15 & $4,070,295$ & 81,406 & 2,714 \\
16 & $4,127,649$ & 82,553 & 2,752 \\
17 & $3,176,756$ & 63,535 & 2,118 \\
18 & $3,422,067$ & 68,441 & 2,281 \\
19 & $2,731,751$ & 54,635 & 1,821 \\
Total & $78,374,206$ & $1,567,484$ & 52,249 \\
\hline
\end{tabular}

Notes: 6MP - Mercaptopurine; $\mathrm{mg}$ - milligrams; $\mathrm{m} 2$ - meters squared; $\mathrm{ml}$ - milliliters.

Setting 2 centers typically have intermediate supportive care and an approximate 5-year eventfree survival of 50-65\%. Population data retrieved from Philippine Statistics Authority. (2017). Philippine Population Surpassed the 100 Million Mark (Results from the 2015 Census of Population). Retrieved from https://www.psa.gov.ph/content/philippine-population-surpassed100-million-mark-results-2015-census-population. Length/height and weight data retrieved from the World Health Organization (WHO) and Centers for Disease Control and Prevention (CDC) growth charts at

https://www.cdc.gov/growthcharts/who charts.htm\#The\%20WHO\%20Growth\%20Charts on 0819-2019. Risk group percentages based upon ALL-BFM study group from 1981 to 2000.

Dosage based upon International Society of Pediatric Oncology (SIOP) Adapted Regimen for Acute Lymphoblastic Leukemia (ALL) - Step 2 Center. 
Table 2-3. Mercaptopurine needed at $100 \%$ Setting 1 centers

\begin{tabular}{lccc}
\hline Age & Total mg of 6MP & $\begin{array}{c}\text { Approximate } \\
\mathbf{5 0 m g} \text { tablets }\end{array}$ & $\begin{array}{c}\text { Approximate bottles } \\
\text { of 30 tablets/50mg }\end{array}$ \\
\hline 0 & 953,351 & 19,067 & 636 \\
1 & $2,585,291$ & 51,706 & 1,724 \\
2 & $7,018,212$ & 140,364 & 4,679 \\
3 & $7,892,032$ & 157,841 & 5,261 \\
4 & $6,942,796$ & 138,856 & 4,629 \\
5 & $4,531,556$ & 90,631 & 3,021 \\
6 & $4,723,311$ & 94,466 & 3,149 \\
7 & $3,848,185$ & 76,964 & 2,565 \\
8 & $3,241,362$ & 64,827 & 2,161 \\
9 & $3,589,422$ & 71,788 & 2,393 \\
10 & $3,586,991$ & 71,740 & 2,391 \\
11 & $3,536,509$ & 70,730 & 2,358 \\
12 & $3,175,360$ & 63,507 & 2,117 \\
13 & $3,663,739$ & 73,275 & 2,442 \\
14 & $4,215,123$ & 84,302 & 2,810 \\
15 & $4,248,208$ & 84,964 & 2,832 \\
16 & $4,303,719$ & 86,074 & 2,869 \\
17 & $3,312,306$ & 66,246 & 2,208 \\
18 & $3,564,121$ & 71,282 & 2,376 \\
19 & $2,844,481$ & 56,890 & 1,896 \\
Total & $81,776,075$ & $1,635,522$ & 54,517 \\
\hline & & &
\end{tabular}

Notes: 6MP - mercaptopurine; $\mathrm{mg}$ - milligrams; $\mathrm{m} 2$ - meters squared; $\mathrm{ml}$ - milliliters. Setting 1 Centers indicate limited supportive care and less than a 50\% event-free survival (EFS) rate. Population data retrieved from Philippine Statistics Authority. (2017). Philippine Population Surpassed the 100 Million Mark (Results from the 2015 Census of Population). Retrieved from https://www.psa.gov.ph/content/philippine-population-surpassed-100-million-mark-results-2015census-population. Length/height and weight data retrieved from the World Health Organization (WHO) and Centers for Disease Control and Prevention (CDC) growth charts at https://www.cdc.gov/growthcharts/who charts.htm\#The $\% 20$ WHO $\% 20$ Growth $\% 20$ Charts on 0819-2019. Risk group percentages based upon ALL-BFM study group from 1981 to 2000. Dosage based upon International Society of Pediatric Oncology (SIOP) Adapted Regimen for Acute Lymphoblastic Leukemia (ALL) - Step 1 Center. 
Table 2-4. Mercaptopurine needed to cover $100 \%$ of children in the Philippines using the Setting 3 regimens

\begin{tabular}{lccc}
\hline Age & $\begin{array}{c}\text { Total mg of 6MP } \\
\text { for Step 3 }\end{array}$ & $\begin{array}{c}\text { Approximate } \\
\mathbf{5 0 m g} \text { tablets }\end{array}$ & $\begin{array}{c}\text { Approximate bottles } \\
\text { of 30 tablets/50mg }\end{array}$ \\
\hline 0 & $884,137.40$ & 17,683 & 29,471 \\
1 & $2,467,314.11$ & 49,346 & 82,244 \\
2 & $6,698,085.79$ & 133,962 & 223,270 \\
3 & $7,532,152.97$ & 150,643 & 251,072 \\
4 & $6,626,182.28$ & 132,524 & 220,873 \\
5 & $4,324,975.93$ & 86,500 & 144,166 \\
6 & $4,508,318.88$ & 90,166 & 150,277 \\
7 & $3,672,857.90$ & 73,457 & 122,429 \\
8 & $3,093,823.68$ & 61,876 & 103,127 \\
9 & $3,426,150.95$ & 68,523 & 114,205 \\
10 & $3,423,459.32$ & 68,469 & 114,115 \\
11 & $3,375,936.07$ & 67,519 & 112,531 \\
12 & $3,031,400.50$ & 60,628 & 101,047 \\
13 & $3,497,557.47$ & 69,951 & 116,585 \\
14 & $4,023,137.52$ & 80,463 & 134,105 \\
15 & $4,054,130.37$ & 81,083 & 135,138 \\
16 & $4,107,786.70$ & 82,156 & 136,926 \\
17 & $3,161,313.08$ & 63,226 & 105,377 \\
18 & $3,402,487.65$ & 68,050 & 113,416 \\
19 & $2,715,607.92$ & 54,312 & 90,520 \\
Total & $78,026,816.49$ & $1,560,536$ & 52,018 \\
\hline
\end{tabular}

Notes: $6 \mathrm{MP}$ - mercaptopurine; $\mathrm{mg}$ - milligrams; $\mathrm{m} 2$ - meters squared; $\mathrm{ml}$, milliliters.

Setting 1 Centers indicate limited supportive care and less than a 50\% event-free survival (EFS) rate. Population data retrieved from Philippine Statistics Authority. (2017). Philippine Population Surpassed the 100 Million Mark (Results from the 2015 Census of Population). Retrieved from https://www.psa.gov.ph/content/philippine-population-surpassed-100-million-mark-results-2015census-population. Length/height and weight data retrieved from the World Health Organization (WHO) and Centers for Disease Control and Prevention (CDC) growth charts at https://www.cdc.gov/growthcharts/who charts.htm\#The\%20WHO\%20Growth\%20Charts on 0819-2019. Risk group percentages based upon ALL-BFM study group from 1981 to 2000. Dosage based upon International Society of Pediatric Oncology (SIOP) Adapted Regimen for Acute Lymphoblastic Leukemia (ALL) - Step 3 Center. 
No published population-based studies were available to assign risk groups to Filipino children using data from the Philippines at the national level, so data from five consecutive ALL trials with the Berlin-Frankfurt-Munster (BFM) protocol from 1981 to 2000 were used to estimate the percentages of patients who would be expected to fall into each risk stratum (Moricke et al., 2010). The BFM protocols from 1981 to 2000 included 6,607 children, of whom $2,435(37 \%)$ were low risk, 3,479 (53\%) were medium risk, and $693(10 \%)$ were high risk. These percentages were used for the risk group estimates in the prediction model. Although the risk nomenclature for the SIOP Adapted ALL and BFM protocols are different, the criteria for the risk stratifications are similar and interchangeable.

\section{Results}

The estimated annual incidence of ALL in the Philippines for children 0-19 years of age was 1,523 (Table 2-1). Assuming that all centers treated according to the SIOP Adapted ALL Regimens for setting 2, the estimated maximum quantity of 6MP for children 0-19 years of age was $1,567,48450 \mathrm{mg}$ tablets per year, equating to approximately $130,00050 \mathrm{mg}$ tablets per month (Table 2-2). The estimated maximum 6MP quantities for children and adolescents diagnosed with ALL in the Philippines is depicted for the 3 setting types in Tables 2-2 to 2-4. Estimated leukemia risk groups by age cohort and sex are depicted in Table 2-5, with 564 (37\%) at lower risk, $807(53 \%)$ at higher risk, and $152(10 \%)$ at very high risk.

\section{Sensitivity Analysis for Incidence}

Incidence estimated from age-standardized rates may not apply to all countries, with incidence rates varying among countries with high-quality, population-based cancer registries. For example, the CDC estimated the incidence of ALL as 34.0 cases per 1 million children at 019 years of age, which would predict 1,437 children per year with ALL in the Philippines or $5.6 \%$ less than our estimate of 1,523 (Siegel et al., 2017). The NCI estimated the incidence of ALL as 41 cases per million children who are $0-14$ years of age and 17 cases per million children 15-19 years of age, which would predict 1,490 children per year with ALL in the Philippines or $2.2 \%$ less than our estimates (National Cancer Institute, 2018). Though variations in incidence have been reported as minimal across countries, we proposed adding $10 \%$ to the monthly estimated need since prevention of shortages is paramount to maximize the cure rate and reduce morbidity, mortality, and costs associated with treating relapsed ALL (Katz et al., 2015).

\section{Sensitivity Analysis for Height, Weight, and Body Surface Area}

Chemotherapy predictions utilizing standardized, non-country specific growth charts may introduce errors in the estimated need. The WHO and CDC growth curves follow well-defined standards and references, but values for children in each country inevitably differ among regions or ethnic groups even within the same country, having variability in weights and heights at each age. Therefore, WHO and CDC growth curves for Filipino children may overestimate chemotherapy needs (de Onis, Blossner, \& Borghi, 2010; Poskitt, 2014). For example, the WHO 
Table 2-5. Demographic information about children with acute lymphoblastic leukemia in the Philippines

\begin{tabular}{|c|c|c|c|c|c|c|c|c|c|c|c|c|}
\hline \multirow[b]{2}{*}{ Age } & \multicolumn{3}{|c|}{ Childhood ALL cases } & \multicolumn{2}{|c|}{ Length/height } & \multicolumn{2}{|c|}{ Weight } & \multicolumn{2}{|c|}{ Surface area } & \multicolumn{3}{|c|}{ Risk group } \\
\hline & $\begin{array}{l}\text { ALL } \\
\text { cases }\end{array}$ & Female & Male & Female & Male & Female & Male & Female & Male & $\begin{array}{l}37 \% \\
\text { lower }\end{array}$ & $\begin{array}{c}53 \% \\
\text { higher }\end{array}$ & $\begin{array}{l}10 \% \\
\text { Very } \\
\text { high }\end{array}$ \\
\hline 0 & 42 & 20 & 21 & 65.73 & 67.62 & 7.30 & 7.93 & 0.37 & 0.39 & 15 & 22 & 4 \\
\hline 1 & 96 & 47 & 50 & 74.02 & 75.75 & 8.95 & 9.65 & 0.43 & 0.45 & 36 & 51 & 10 \\
\hline 2 & 215 & 104 & 111 & 86.42 & 87.82 & 11.48 & 12.15 & 0.52 & 0.54 & 79 & 114 & 21 \\
\hline 3 & 212 & 103 & 110 & 93.92 & 94.96 & 13.87 & 14.33 & 0.60 & 0.61 & 79 & 113 & 21 \\
\hline 4 & 169 & 82 & 87 & 100.75 & 102.22 & 15.79 & 16.23 & 0.66 & 0.68 & 63 & 90 & 17 \\
\hline 5 & 100 & 48 & 52 & 107.66 & 108.90 & 17.93 & 18.39 & 0.73 & 0.75 & 37 & 53 & 10 \\
\hline 6 & 96 & 46 & 49 & 114.71 & 115.39 & 20.24 & 20.68 & 0.80 & 0.81 & 35 & 51 & 10 \\
\hline 7 & 72 & 35 & 37 & 121.49 & 121.77 & 22.76 & 23.07 & 0.88 & 0.88 & 26 & 38 & 7 \\
\hline 8 & 56 & 27 & 29 & 127.59 & 127.88 & 25.63 & 25.64 & 0.95 & 0.95 & 21 & 29 & 6 \\
\hline 9 & 57 & 28 & 29 & 132.92 & 133.51 & 28.99 & 28.55 & 1.03 & 1.03 & 21 & 30 & 6 \\
\hline 10 & 53 & 25 & 27 & 137.99 & 138.62 & 32.89 & 31.94 & 1.12 & 1.11 & 19 & 28 & 5 \\
\hline 11 & 48 & 23 & 25 & 143.98 & 143.52 & 37.21 & 35.89 & 1.22 & 1.20 & 18 & 25 & 5 \\
\hline 12 & 40 & 19 & 20 & 151.19 & 149.05 & 41.65 & 40.47 & 1.32 & 1.29 & 15 & 21 & 4 \\
\hline 13 & 43 & 21 & 22 & 157.15 & 156.09 & 45.82 & 45.59 & 1.41 & 1.41 & 16 & 23 & 4 \\
\hline 14 & 46 & 22 & 24 & 160.39 & 163.84 & 49.36 & 51.00 & 1.48 & 1.52 & 17 & 24 & 5 \\
\hline 15 & 44 & 21 & 23 & 161.86 & 169.94 & 52.04 & 56.28 & 1.53 & 1.63 & 16 & 23 & 4 \\
\hline 16 & 43 & 21 & 22 & 162.55 & 173.51 & 53.88 & 60.92 & 1.56 & 1.71 & 16 & 23 & 4 \\
\hline 17 & 32 & 16 & 17 & 162.91 & 175.29 & 55.14 & 64.57 & 1.58 & 1.77 & 12 & 17 & 3 \\
\hline 18 & 34 & 17 & 17 & 163.12 & 176.16 & 56.19 & 67.20 & 1.60 & 1.81 & 13 & 18 & 3 \\
\hline 19 & 27 & 13 & 14 & 163.25 & 176.60 & 57.30 & 69.12 & 1.61 & 1.84 & 10 & 14 & 3 \\
\hline Total & 1,523 & 738 & 785 & & & & & & & 564 & 807 & 152 \\
\hline
\end{tabular}

Notes: Length/Height, Weight data retrieved from the World Health Organization (WHO) and Centers for Disease Control and Prevention (CDC) growth charts https://www.cdc.gov/growthcharts/who_charts.htm\#The\%20WHO\%20Growth\%20Charts. Surface area calculated via Mosteller formula. Risk group percentages based upon ALL-BFM study group from 1981 to 2000. 
reported that $12.8 \%$ of Filipino children are overweight compared to $41.8 \%$ in the US (World Health Organization, 2018); greater obesity among children in the US and more growth-stunting in the Philippines could lead to underestimation of chemotherapy needed for children in the US and overestimation of chemotherapy needed for children in the Philippines (World Health Organization, 2018). Where age-specific obesity rates are known, the model could be refined, but we favor the use of individual patient data to create exact forecasts by patient, center, region, and country rather than attempts to increase the precision of the forecast beyond what is necessary to prevent stock-outs and shortages. However, doses of 6MP and other chemotherapy agents are calculated by body surface area rather than weight, and the increase in dose varies with the square root of the increase in weight. Therefore, a child weighing $100 \%$ more than the mean weight for a given age would require only $41 \%$ more chemotherapy.

\section{Discussion}

\section{Summary of Findings}

Forecasting the maximum quantity of 6MP is feasible using existing public data sources. Such forecasting is the first step in assuring an uninterrupted supply of essential chemotherapy, and this method may be applied to other chemotherapy agents. Estimation of the maximum quantity needed may serve as the foundation for other chemotherapy estimates. The actual requirement could be calculated if misdiagnosis, refusal, abandonment, and death could be calculated. Other considerations should include the feasibility of preparing liquid formulations and the stability of formulations as well as the need to cut pills according to prescribed dose. Dosing variations may require cutting 6MP tablets into fourths (e.g., for a dose of $62.5 \mathrm{mg}$ per day, which requires $1 \frac{1 / 4}{4}$ tablets). However, pending more nuanced estimates, procurement based on the upper bound could ensure a fixed minimal inventory sufficient to supply the country with the drug (or hospital or individual) should a replacement in supplier be needed.

\section{Strengths of Study}

The primary strength of this study was the projection of maximum chemotherapy needed using publicly available statistics. Census data in the Philippines are of high quality and available in yearly intervals. The WHO and CDC growth charts could be used for any country, and SEER incidence rates do not differ dramatically from incidence rates in other countries (Allemani et al., 2015; Centers for Disease Control and Prevention, 2010). SIOP Adapted ALL Regimens are appropriate for all countries, and the various regimens include approximately the same amount of 6MP (but not other agents), such that even if the regimens used at each cancer center within a country are not known, the 6MP forecast is accurate (Hunger et al., 2009).

\section{Weaknesses of Study}

Using surrogate measures of ALL incidence, non-Filipino growth curves to calculate doses needed at each age, and imputed percentages of each ALL risk group may introduce errors 
in estimated chemotherapy needs. Furthermore, the census population at each age was based on 2015 data, and the number of patients at each age group may have been higher or lower according to the change in population from the time of the census used for the forecast. The forecast model did not use in-country ALL incidence rate, risk stratification, height and weight, and actual patient adherence or treatment regimen. Patient-level data addressed all of these weaknesses and directly measured incidence and relied on measurement of patients' actual height and weight rather than estimates from population curves. Patient-level data also considered the treatment regimen used and critical outcomes that would affect the amount of 6MP needed. Information systems are also available at no cost (e.g., http://www.amplifyinghealth.org/), facilitating direct measurements and calculation of a patient's forecasted individualized need.

\section{Future Directions Regarding Information Systems}

An information system that collects patient-level data could simultaneously create accurate forecasts and document when access to essential chemotherapy is limited, serving as a large-scale early warning system for drug shortages. Patient-level data allow forecasting at the individual level to ensure an adequate supply for the specific patient, aggregated at the center level, according to regional and national forecasts for bulk purchasing and procurement of adequate supplies. An information system that captures refusal, toxic death, abandonment, and relapse may allow adjustments to the forecasting model to more accurately reflect actual utilization of essential chemotherapy. A forecast based on patient-level information can inform governmental agencies charged with provision of a continuous supply of essential medicines and may prevent future shortages by ensuring that a 6-month supply is always on hand. The information system can be linked to health insurance coverage to ensure that it corresponds to patients' needs and allows nuanced application of national funding mechanisms like the PhilHealth Z-package designed for coverage of severe conditions (PhilHealth, 2018).

More work is needed, but ALL is a curable cancer at a relatively low cost. Assuring an uninterrupted supply of essential chemotherapy is feasible. Age-standardized incidence rates, growth curves, imputed risk stratification, and census data enable forecasting by cancer type and chemotherapy agent at any level of society (individual, hospital, and nation). Such models can inform healthcare policy and eliminate needless deaths from curable cancers that would otherwise result because of the unavailability of low-cost, essential drugs and resources.

\section{Conclusion}

Forecasting the maximum national needs for chemotherapeutic agents is feasible using existing public data sources. However, in-country patient-level information that includes refusal, abandonment, toxic death, and relapse is needed to estimate needs more precisely. Our results showed that using such models could help to effectively treat curable cancers worldwide. 


\section{CHAPTER 3. FORECASTING THE ESSENTIAL CHEMOTHERAPY NEEDED FOR TREATMENT OF CHILDREN WITH ACUTE LYMPHOBLASTIC LEUKEMIA IN LOW- AND MIDDLE-INCOME COUNTRIES: TANZANIA, HONDURAS, AND VENEZUELA}

\section{Introduction}

Acute lymphoblastic leukemia (ALL) is the most common pediatric cancer, with contemporary therapy resulting in $90 \%$ survival in high-income countries (HIC) (Cooper \& Brown, 2015; Essig et al., 2014; Jaime-Perez et al., 2016; Jeha et al., 2019). An estimated 87\% of the world's children live in low- and middle-income countries (LMIC) where ALL cure can be elusive (Allemani et al., 2015; Bhakta et al., 2013; Cooper \& Brown, 2015; Jabbour et al., 2018; Jaime-Perez et al., 2016; Magrath et al., 2013; Pribnow et al., 2017; Redaniel et al., 2010).

Treatment failures in LMIC have been identified as incorrect or delayed diagnosis, abandonment, treatment refusal, and preventable relapse (Howard et al., 2017). Preventable relapse occurs when a child lacks access to essential chemotherapy resulting from systemic factors including stock-outs and national or regional drug shortages (Ruff et al., 2016). Other contributing factors may include insufficient medical infrastructure and family resources. Insufficient medical infrastructure contributes to inadequate access to tests necessary for diagnosis and patient risk stratification (Jeha et al., 2019; Ruff et al., 2016). Utilization of suboptimal chemotherapy treatment regimens, insufficient access to cancer treatment centers, lack of oncological healthcare providers, and lack of supportive care are also problematic (Hunger et al., 2009; Jeha et al., 2019; Ruff et al., 2016). Insufficient family resources may result in lack of access to care due to barriers of transportation, costs of food and lodging near the treatment center, and costs for medical services (Howard et al., 2017; Ruff et al., 2016).

Through the SIOP ALL Adapted Regimens, efforts have been implemented to address the essential chemotherapy needs for treatment of ALL in LMIC (Hunger et al., 2009). The SIOP ALL Adapted Regimens were developed with consideration of the cancer center and supportive care infrastructure within LMIC. The protocol describes three levels of care, with four treatment regimens comprised of 6 to 9 medications, all of which the WHO and SIOP Pediatric Oncology in Developing Countries (PODC) Essential Medicines Working Group consider essential chemotherapy (Mehta et al., 2013; World Health Organization, 2019). Within the SIOP ALL Adapted Regimens, all chemotherapy is generic, available from multiple distributors, and relatively affordable. Although protocols are center-specific and the essential chemotherapy is generic and affordable, achieving higher ALL cure rates in LMIC is not possible without an adequate supply of essential chemotherapy.

Drug shortages are multifactorial and occur in both HIC and LMIC (Iyengar, Hedman, Forte, \& Hill, 2016). Sixty-six percent of drug shortages are directly related to manufacturing and have become more prevalent in recent years, especially for inexpensive generic drugs (World Heath Organization, 2016). Less often (14\%), drug shortages are related to discontinuation of the product, raw material shortage (8\%), increased demand $(6 \%)$, and loss of a manufacturing site (4\%) (Fisher, Wicks, \& Babar, 2016; Gray \& Manasse, 2012; Iyengar et al., 
2016; United States Food and Drug Administration, 2013; World Heath Organization, 2016). A reliable estimate of the annual essential chemotherapy need would enable a country to strategically manage purchasing and inventory to mitigate a drug shortage. This strategical buying would allow any country the ability to have essential chemotherapy on-hand within a predicted time frame. Should supply problems arise, this predictive buying plan would allow the patient to continue ALL treatment while health care officials resolve upstream supply issues. This chapter describes a forecasting model that utilizes three readily available data sources to predict the annual incidence of pediatric ALL and the quantity of essential chemotherapy needed to treat each child and adolescent diagnosed with ALL. Three countries-Tanzania, Honduras, Venezuela - serve as examples of low-income, lower middle-income, and upper middle-income countries for this forecasting model (Centers for Disease Control and Prevention, 2010; National Institutes of Health, 2010; United Nations, 2019; World Bank, 2018).

\section{Methods}

\section{Protocols for Acute Lymphoblastic Leukemia}

The SIOP Adapted ALL protocol regimen adapted for LMIC was used for the forecasting model (Hunger et al., 2009). This protocol stratifies risk by age, white blood cell count, central nervous system status at diagnosis, and early response to treatment (Hunger et al., 2009). The three risk categories include lower risk, higher risk, and very high risk. No published populationbased studies were available to assign risk groups to children in Tanzania, Honduras, or Venezuela. Therefore, data from five consecutive ALL trials with the Berlin-Frankfurt-Munster (BFM) protocol from 1981 to 2000 were used to estimate the percentages of patients expected to fall into each risk stratum (Moricke et al., 2010). The BFM protocols enrolled 6,607 children and classified $37 \%$ as low risk, $53 \%$ medium risk, and $10 \%$ high risk. These risk group percentages were used in the forecasting model. Although the risk nomenclature for the SIOP Adapted ALL and BFM protocols vary, the criteria for the risk stratifications are similar and interchangeable.

In addition to three risk strata, the SIOP ALL Adapted Regimens includes three oncology center models which identify the optimal regimen for each patient based upon ALL risk strata and center resources (Howard et al., 2017). Setting 1 centers are described as providing limited supportive care with intensive chemotherapy regimens, resulting in an unacceptably high rate of toxic death. Setting 2 centers are described as providing intermediate supportive care, while setting 3 centers are described as resembling those in HIC.

\section{Body Surface Area Estimates}

The WHO and CDC growth charts provided length and height and weight for males and females to calculate body surface area at 1-year intervals for patients 0-19 years of age (Centers for Disease Control and Prevention, 2010). WHO length and weight charts were used for males and females from age 0-24 months of age, while the CDC growth charts were used for males and females 3-19 years of age. WHO length and growth charts were used for infants and toddlers 0- 
24 months. These growth charts are recommended and provide normative standards for breastfed children and are more consistent with the physiological description of growth in infancy. WHO growth charts do not provide data for children over 5; however, the methods for CDC and WHO growth charts are similar for children 2-5 years of age and both are based on rigorous study designs for growth assessment (Centers for Disease Control and Prevention, 2010).

\section{Acute Lymphoblastic Leukemia Incidence Estimates}

The United Nations (UN) 2019 World Populations Prospects for 2020 was used to determine the population by gender and age (United Nations, 2019). NIH, NCI, and SEER CSR 1975-2010 data determined the annual incidence of ALL by gender and age. The estimated ALL incidence rate for each age and gender was determined by multiplying the incidence rate by the population for children 0-19 years of age. The estimated dose requirement for each age and gender was determined by multiplying the SIOP ALL Adapted Regimens dosing by the body surface area calculated via the WHO and CDC growth charts.

\section{Results}

The estimated annual incidence of ALL among children and adolescents 0 -19 years of age was as follows: Tanzania - 1,236; Honduras - 144; and Venezuela - 356 (Table 3-1). The estimated risk stratification for Tanzania, Honduras, and Venezuela is 37\% lower risk, 53\% higher risk, and 10\% very high risk. Previous studies have reported variations in ALL incidence across geographic regions, while recent data have shown minimal variation among countries. This minimal variation could reflect the consensus-based classification of hematologic malignancies developed by the WHO (Groves, 2017; Katz et al., 2015). Table 1depicts these differences, where the CDC estimates the incidence of ALL as 34.0 cases per 1 million children 0-19 years of age (Siegel et al., 2017). The NCI estimated the incidence of ALL as 41 cases per 1 million children aged 0-14 years of age and 17 cases per million children 15-19 years of age (Lam et al., 2019). SEER estimated the incidence of ALL for each year of age for children from 0-19 years (National Institutes of Health, 2010).

Table 3-2 depicts the forecasted maximum quantity of essential chemotherapy needed to treat every child and adolescent diagnosed with ALL without cranial irradiation (CRT) within a Step 1 medical center in Honduras, Tanzania, and Venezuela. The average milligram (mg) dosage of essential chemotherapies for one child in each country is also calculated. When the average mg of each essential chemotherapy per child was multiplied by the ALL incidence for each country, the resulting chemotherapy requirements had a variability of less than $5 \%$ for each country (see Table 3-2 and Tables 3-3 to 3-5).

The four SIOP ALL Adapted Regimens are as follows. Regimen 1 requires 6 essential chemotherapies, while Regimens 2 through 4 require 9 with the addition of doxorubicin, cyclophosphamide, and cytarabine. Regimen 4 requires 687 doses of 6-mercaptopurine; 775 doses for Regimen 3; 765 for Regimen 2; and 868 for Regimen 1. Regimen 1 requires 9 doses of L-asparaginase, while regimens 2, 3, and 4 require 15 doses (Table 3-6). 
Table 3-1. Number of children at each age group and expected cases of acute lymphoblastic leukemia in four countries

\begin{tabular}{lcccc}
\hline Number of children per age group & Philippines & Tanzania & Honduras & Venezuela \\
\hline Children ages 0-4 years & $10,616,342$ & $9,738,602$ & $1,017,015$ & $2,363,409$ \\
Children ages 5-9 years & $11,397,952$ & $8,623,714$ & 988,975 & $2,731,190$ \\
Children ages 10-14 years & $10,906,801$ & $7,654,580$ & $1,023,645$ & $2,657,796$ \\
Children ages 15-19 years & $10,462,894$ & $6,434,462$ & $1,040,990$ & $2,500,772$ \\
Total Childhood Population 2020 & $43,383,989$ & $32,451,358$ & $4,070,625$ & $10,253,167$ \\
Expected cases of ALL each year (SEER) & 1,523 & 1,236 & 144 & 356 \\
Expected cases of ALL each year (NCI) & 1,528 & $1176(-$ & $142(-1.2 \%)$ & $360(1.1 \%)$ \\
and percentage difference from SEER & $(0.3 \%)$ & $4.8 \%)$ & & \\
Expected cases of ALL each year (CDC) & $1475 /-3.1 \%$ & $1103 /-$ & $138 /-3.6 \%$ & $349 / 2.2 \%$ \\
and percentage difference from SEER & & $10.7 \%$ & & \\
\hline
\end{tabular}

Notes: Total Childhood Population from the United Nations World Population Prospects https://population.un.org/wpp/Download/Standard/Population/

ALL - Acute lymphoblastic leukemia; SEER - Surveillance, Epidemiology, and End Results; NCI - National Cancer Institute; CDC - Centers for Disease Control and Prevention. SEER Incidence determined via yearly intervals

https://seer.cancer.gov/archive/csr/1975 2010/browse csr.php?sectionSEL=28\&pageSEL=sect 28 table.13.html. NCI, Expected incidence of 41 cases per 1 million for ages 0-14, and 17 cases per 1 million for ages 15-19 retrieved from https://www.cancer.gov/types/leukemia/hp/child-alltreatment-pdq\#cit/section_1.4. CDC, Expected incidence of 34 cases per 1 million retrieved from https://www.cdc.gov/mmwr/volumes/66/wr/mm6636a3.htm\#T1_down 
Table 3-2. Forecasted quantities of each essential medication required to deliver the SIOP Adapted ALL Regimen Level 1 without cranial radiation in three countries

\begin{tabular}{|c|c|c|c|c|c|c|}
\hline Medication & Country & $\begin{array}{c}\text { Medication } \\
\text { per model }\end{array}$ & $\begin{array}{c}\text { Average } \\
\text { medication } \\
\text { amount } \\
\text { per child } \\
\text { by country } \\
\end{array}$ & $\begin{array}{l}\text { Average } \\
\text { child for } \\
\text { the three } \\
\text { countries } \\
\text { (standard } \\
\text { deviation) }\end{array}$ & $\begin{array}{c}\text { Forecast of } \\
\text { medication } \\
\text { needed using } \\
\text { an average } \\
\text { from three } \\
\text { countries } \\
\end{array}$ & $\begin{array}{c}\text { Percent } \\
\text { difference }\end{array}$ \\
\hline \multirow{3}{*}{$\begin{array}{l}\text { Prednisone } \\
(\mathrm{mg})\end{array}$} & Tanzania & $1,345,573$ & 1,089 & \multirow{3}{*}{$\begin{array}{l}1,140 \\
(44)\end{array}$} & $1,408,628$ & -4 \\
\hline & Venezuela & 417,200 & 1,171 & & 405,721 & 3 \\
\hline & Honduras & 166,463 & 1,159 & & 164,112 & 1 \\
\hline \multirow{3}{*}{$\begin{array}{l}\text { Vincristine } \\
(\mathrm{mg})\end{array}$} & Tanzania & 53,721 & 43 & \multirow{3}{*}{$\begin{array}{l}46 \\
(2)\end{array}$} & 56,444 & -5 \\
\hline & Venezuela & 16,746 & 47 & & 16,257 & 3 \\
\hline & Honduras & 6,758 & 47 & & 6,576 & 3 \\
\hline \multirow{3}{*}{$\begin{array}{l}\text { L-asparaginase } \\
\text { (international } \\
\text { units) }\end{array}$} & Tanzania & $55,893,017$ & 45,231 & \multirow{3}{*}{$\begin{array}{l}47,336 \\
(1,839)\end{array}$} & $58,507,708$ & -4 \\
\hline & Venezuela & $17,329,852$ & 48,626 & & $16,851,735$ & 3 \\
\hline & Honduras & $6,914,616$ & 48,152 & & $6,816,432$ & 1 \\
\hline \multirow{3}{*}{$\begin{array}{l}\text { Intrathecal } \\
\text { methotrexate } \\
\text { (mg) }\end{array}$} & Tanzania & 296,573 & 240 & \multirow{3}{*}{$\begin{array}{r}240 \\
(0)\end{array}$} & 296,640 & 0 \\
\hline & Venezuela & 85,534 & 240 & & 85,440 & 0 \\
\hline & Honduras & 34,464 & 240 & & 34,560 & 0 \\
\hline \multirow{3}{*}{$\begin{array}{l}\text { Methotrexate oral } \\
\text { (mg) }\end{array}$} & Tanzania & $2,194,318$ & 1,776 & \multirow{3}{*}{$\begin{array}{c}1,858 \\
(72)\end{array}$} & $2,296,900$ & -4 \\
\hline & Venezuela & 680,357 & 1,909 & & 661,567 & 3 \\
\hline & Honduras & 271,463 & 1,890 & & 267,600 & 1 \\
\hline \multirow{3}{*}{$\begin{array}{l}\text { Methotrexate IV } \\
\text { (mg) }\end{array}$} & Tanzania & 0 & 0 & \multirow{3}{*}{$\begin{array}{c}0 \\
(0)\end{array}$} & 0 & 0 \\
\hline & Venezuela & 0 & 0 & & 0 & 0 \\
\hline & Honduras & 0 & 0 & & 0 & 0 \\
\hline \multirow{3}{*}{$\begin{array}{l}\text { Dexamethasone } \\
(\mathrm{mg})\end{array}$} & Tanzania & 931,550 & 754 & \multirow{3}{*}{$\begin{array}{l}789 \\
(31)\end{array}$} & 975,204 & -4 \\
\hline & Venezuela & 288,831 & 810 & & 280,884 & 3 \\
\hline & Honduras & 115,244 & 803 & & 113,616 & 1 \\
\hline \multirow{3}{*}{$\begin{array}{l}\text { Mercaptopurine } \\
(\mathrm{mg})\end{array}$} & Tanzania & $67,382,137$ & 54,529 & \multirow{3}{*}{$\begin{array}{l}57,067 \\
(2,216)\end{array}$} & $70,534,400$ & -4 \\
\hline & Venezuela & $20,892,099$ & 58,621 & & $20,315,733$ & 3 \\
\hline & Honduras & $8,335,953$ & 58,050 & & $8,217,600$ & 1 \\
\hline \multirow{3}{*}{$\begin{array}{l}\text { Doxorubicin } \\
\text { (mg) }\end{array}$} & Tanzania & 0 & 0 & \multirow{3}{*}{$\begin{array}{c}0 \\
(0)\end{array}$} & 0 & 0 \\
\hline & Venezuela & 0 & 0 & & 0 & 0 \\
\hline & Honduras & 0 & 0 & & 0 & 0 \\
\hline
\end{tabular}


Table 3-2. (Continued)

\begin{tabular}{|c|c|c|c|c|c|c|}
\hline Medication & Country & $\begin{array}{l}\text { Medication } \\
\text { per model }\end{array}$ & $\begin{array}{c}\text { Average } \\
\text { medication } \\
\text { amount } \\
\text { per child } \\
\text { by country } \\
\end{array}$ & $\begin{array}{l}\text { Average } \\
\text { child for } \\
\text { the three } \\
\text { countries } \\
\text { (standard } \\
\text { deviation) }\end{array}$ & $\begin{array}{c}\text { Forecast of } \\
\text { medication } \\
\text { needed using } \\
\text { an average } \\
\text { from three } \\
\text { countries } \\
\end{array}$ & $\begin{array}{c}\text { Percent } \\
\text { difference }\end{array}$ \\
\hline \multirow[t]{3}{*}{ Cyclophosphamide(mg) } & Tanzania & 0 & 0 & \multirow{3}{*}{$\begin{array}{c}0 \\
(0)\end{array}$} & 0 & 0 \\
\hline & Venezuela & 0 & 0 & & 0 & 0 \\
\hline & Honduras & 0 & 0 & & 0 & 0 \\
\hline \multirow{3}{*}{$\begin{array}{l}\text { Cytarabine } \\
(\mathrm{mg})\end{array}$} & Tanzania & 0 & 0 & \multirow{3}{*}{$\begin{array}{c}0 \\
(0)\end{array}$} & 0 & 0 \\
\hline & Venezuela & 0 & 0 & & 0 & 0 \\
\hline & Honduras & 0 & 0 & & 0 & 0 \\
\hline
\end{tabular}

Notes: SIOP - International Society of Paediatric Oncology; ALL - Acute lymphoblastic leukemia; mg - Milligrams; IV - Intravenous 
Table 3-3. Forecasted quantities of each essential medication required to deliver the SIOP Adapted ALL Regimen Level 1 with cranial radiation in three countries

\begin{tabular}{|c|c|c|c|c|c|c|}
\hline Medication & Country & $\begin{array}{l}\text { Medication } \\
\text { per model }\end{array}$ & $\begin{array}{c}\text { Average } \\
\text { medication } \\
\text { amount } \\
\text { per child } \\
\text { by country }\end{array}$ & $\begin{array}{l}\text { Average } \\
\text { child for } \\
\text { the three } \\
\text { countries } \\
\text { (standard } \\
\text { deviation) }\end{array}$ & $\begin{array}{c}\text { Forecast of } \\
\text { medication } \\
\text { needed } \\
\text { using an } \\
\text { average } \\
\text { from three } \\
\text { countries }\end{array}$ & $\begin{array}{c}\text { Percent } \\
\text { difference }\end{array}$ \\
\hline \multirow{3}{*}{$\begin{array}{l}\text { Prednisone } \\
(\mathrm{mg})\end{array}$} & Tanzania & $1,345,573$ & 1,089 & \multirow{3}{*}{$\begin{array}{l}1,140 \\
(44)\end{array}$} & $1,408,628$ & -4 \\
\hline & Venezuela & 417,200 & 1,171 & & 405,721 & 3 \\
\hline & Honduras & 166,463 & 1,159 & & 164,112 & 1 \\
\hline \multirow{3}{*}{$\begin{array}{l}\text { Vincristine } \\
(\mathrm{mg})\end{array}$} & Tanzania & 53,721 & 43 & \multirow{3}{*}{$\begin{array}{l}46 \\
(2)\end{array}$} & 56,444 & -5 \\
\hline & Venezuela & 16,746 & 47 & & 16,257 & 3 \\
\hline & Honduras & 6,758 & 47 & & 6,576 & 3 \\
\hline \multirow{3}{*}{$\begin{array}{l}\text { L-asparaginase } \\
\text { (international units) }\end{array}$} & Tanzania & $55,893,017$ & 45,231 & \multirow{3}{*}{$\begin{array}{l}47,336 \\
(1,839)\end{array}$} & $58,507,708$ & -4 \\
\hline & Venezuela & $17,329,852$ & 48,626 & & $16,851,735$ & 3 \\
\hline & Honduras & $6,914,616$ & 48,152 & & $6,816,432$ & 1 \\
\hline \multirow{3}{*}{$\begin{array}{l}\text { Intrathecal } \\
\text { methotrexate } \\
(\mathrm{mg})\end{array}$} & Tanzania & 259,205 & 210 & \multirow{3}{*}{$\begin{array}{l}210 \\
(0)\end{array}$} & 259,560 & 0 \\
\hline & Venezuela & 74,757 & 210 & & 74,760 & 0 \\
\hline & Honduras & 30,121 & 210 & & 30,240 & 0 \\
\hline \multirow{3}{*}{$\begin{array}{l}\text { Methotrexate oral } \\
\text { (mg) }\end{array}$} & Tanzania & $2,246,485$ & 1,818 & \multirow{3}{*}{$\begin{array}{c}1,902 \\
(74)\end{array}$} & $2,351,284$ & -4 \\
\hline & Venezuela & 696,532 & 1,954 & & 677,231 & 3 \\
\hline & Honduras & 277,916 & 1,935 & & 273,936 & 1 \\
\hline \multirow{3}{*}{$\begin{array}{l}\text { Methotrexate IV } \\
(\mathrm{mg})\end{array}$} & Tanzania & 0 & 0 & \multirow{3}{*}{$\begin{array}{c}0 \\
(0)\end{array}$} & 0 & 0 \\
\hline & Venezuela & 0 & 0 & & 0 & 0 \\
\hline & Honduras & 0 & 0 & & 0 & 0 \\
\hline \multirow{3}{*}{$\begin{array}{l}\text { Dexamethasone } \\
(\mathrm{mg})\end{array}$} & Tanzania & 931,550 & 754 & \multirow{3}{*}{$\begin{array}{l}789 \\
(31)\end{array}$} & 975,204 & -4 \\
\hline & Venezuela & 288,831 & 810 & & 280,884 & 3 \\
\hline & Honduras & 115,244 & 803 & & 113,616 & 1 \\
\hline \multirow{3}{*}{$\begin{array}{l}\text { Mercaptopurine } \\
\text { (mg) }\end{array}$} & Tanzania & $67,382,137$ & 54,529 & \multirow{3}{*}{$\begin{array}{l}57,067 \\
(2,216)\end{array}$} & $70,534,400$ & -4 \\
\hline & Venezuela & $20,892,099$ & 58,621 & & $20,315,733$ & 3 \\
\hline & Honduras & $8,335,953$ & 58,050 & & $8,217,600$ & 1 \\
\hline \multirow{3}{*}{$\begin{array}{l}\text { Doxorubicin } \\
\text { (mg) }\end{array}$} & Tanzania & 0 & 0 & \multirow{3}{*}{$\begin{array}{c}0 \\
(0)\end{array}$} & 0 & 0 \\
\hline & Venezuela & 0 & 0 & & 0 & 0 \\
\hline & Honduras & 0 & 0 & & 0 & 0 \\
\hline
\end{tabular}


Table 3-3. (Continued)

\begin{tabular}{|c|c|c|c|c|c|c|}
\hline Medication & Country & $\begin{array}{c}\text { Medication } \\
\text { per model }\end{array}$ & $\begin{array}{c}\text { Average } \\
\text { medication } \\
\text { amount } \\
\text { per child } \\
\text { by country }\end{array}$ & $\begin{array}{l}\text { Average } \\
\text { child for } \\
\text { the three } \\
\text { countries } \\
\text { (standard } \\
\text { deviation) }\end{array}$ & $\begin{array}{c}\text { Forecast of } \\
\text { medication } \\
\text { needed } \\
\text { using an } \\
\text { average } \\
\text { from three } \\
\text { countries }\end{array}$ & $\begin{array}{c}\text { Percent } \\
\text { difference }\end{array}$ \\
\hline \multirow{3}{*}{$\begin{array}{l}\text { Cyclophosphamide } \\
\text { (mg) }\end{array}$} & Tanzania & 0 & 0 & \multirow{3}{*}{$\begin{array}{c}0 \\
(0)\end{array}$} & 0 & 0 \\
\hline & Venezuela & 0 & 0 & & 0 & 0 \\
\hline & Honduras & 0 & 0 & & 0 & 0 \\
\hline \multirow{3}{*}{$\begin{array}{l}\text { Cytarabine } \\
(\mathrm{mg})\end{array}$} & Tanzania & 0 & 0 & \multirow{3}{*}{$\begin{array}{c}0 \\
(0)\end{array}$} & 0 & 0 \\
\hline & Venezuela & 0 & 0 & & 0 & 0 \\
\hline & Honduras & 0 & 0 & & 0 & 0 \\
\hline
\end{tabular}

Notes: SIOP - International Society of Paediatric Oncology; ALL - Acute lymphoblastic leukemia; mg - Milligrams; IV - Intravenous 
Table 3-4. Forecasted quantities of each essential medication required to deliver the SIOP Adapted ALL Regimen Level 2

\begin{tabular}{|c|c|c|c|c|c|c|}
\hline Medication & Country & $\begin{array}{c}\text { Medication } \\
\text { Per model }\end{array}$ & $\begin{array}{c}\text { Average } \\
\text { medication } \\
\text { amount per } \\
\text { child by } \\
\text { country }\end{array}$ & $\begin{array}{l}\text { Average } \\
\text { child for } \\
\text { the three } \\
\text { countries } \\
\text { (standard } \\
\text { deviation) }\end{array}$ & $\begin{array}{c}\text { Forecast of } \\
\text { medication } \\
\text { needed } \\
\text { using an } \\
\text { average } \\
\text { from three } \\
\text { countries }\end{array}$ & $\begin{array}{c}\text { Percent } \\
\text { difference }\end{array}$ \\
\hline \multirow{3}{*}{$\begin{array}{l}\text { Prednisone } \\
(\mathrm{mg})\end{array}$} & Tanzania & $1,632,490$ & 1,321 & \multirow{3}{*}{$\begin{array}{c}1,382 \\
(53)\end{array}$} & $1,707,740$ & -4 \\
\hline & Venezuela & 506,160 & 1,422 & & 491,873 & 3 \\
\hline & Honduras & 201,958 & 1,402 & & 198,960 & 2 \\
\hline \multirow{3}{*}{$\begin{array}{l}\text { Vincristine } \\
(\mathrm{mg})\end{array}$} & Tanzania & 53,362 & 43 & \multirow{3}{*}{$\begin{array}{l}45 \\
(2)\end{array}$} & 55,620 & -4 \\
\hline & Venezuela & 16,545 & 46 & & 16,020 & 3 \\
\hline & Honduras & 6,602 & 46 & & 6,480 & 2 \\
\hline \multirow{3}{*}{$\begin{array}{l}\text { L-asparaginase } \\
\text { (international } \\
\text { units) }\end{array}$} & Tanzania & $79,368,084$ & 64,214 & \multirow{3}{*}{$\begin{array}{l}67,175 \\
(2,607)\end{array}$} & $83,028,300$ & -4 \\
\hline & Venezuela & $24,608,389$ & 69,125 & & $23,914,300$ & 3 \\
\hline & Honduras & $9,818,754$ & 68,186 & & $9,673,200$ & 2 \\
\hline \multirow{3}{*}{$\begin{array}{l}\text { Intrathecal } \\
\text { methotrexate } \\
(\mathrm{mg})\end{array}$} & Tanzania & 309,325 & 250 & \multirow{3}{*}{$\begin{array}{c}250 \\
(1)\end{array}$} & 309,412 & 0 \\
\hline & Venezuela & 89,212 & 251 & & 89,119 & 0 \\
\hline & Honduras & 35,946 & 250 & & 36,048 & 0 \\
\hline \multirow{3}{*}{$\begin{array}{l}\text { Methotrexate oral } \\
(\mathrm{mg})\end{array}$} & Tanzania & $2,020,015$ & 1,634 & \multirow{3}{*}{$\begin{array}{c}1,709 \\
(66)\end{array}$} & $2,112,736$ & -4 \\
\hline & Venezuela & 626,314 & 1,759 & & 608,523 & 3 \\
\hline & Honduras & 249,899 & 1,735 & & 246,144 & 2 \\
\hline \multirow{3}{*}{$\begin{array}{l}\text { Methotrexate IV } \\
(\mathrm{mg})\end{array}$} & Tanzania & 0 & 0 & \multirow{3}{*}{$\begin{array}{c}0 \\
(0)\end{array}$} & 0 & 0 \\
\hline & Venezuela & 0 & 0 & & 0 & 0 \\
\hline & Honduras & 0 & 0 & & 0 & 0 \\
\hline \multirow{3}{*}{$\begin{array}{l}\text { Dexamethasone } \\
(\mathrm{mg})\end{array}$} & Tanzania & 944,592 & 753 & \multirow{3}{*}{$\begin{array}{l}796 \\
(38)\end{array}$} & 983,856 & -4 \\
\hline & Venezuela & 292,874 & 823 & & 283,376 & 3 \\
\hline & Honduras & 116,857 & 812 & & 114,624 & 2 \\
\hline \multirow{3}{*}{$\begin{array}{l}\text { Mercaptopurine } \\
\text { (mg) }\end{array}$} & Tanzania & $33,441,102$ & 26,669 & \multirow{3}{*}{$\begin{array}{l}28,175 \\
(1,319)\end{array}$} & $34,823,888$ & -4 \\
\hline & Venezuela & $10,368,547$ & 29,125 & & $10,030,181$ & 3 \\
\hline & Honduras & $4,137,053$ & 28,730 & & $4,057,152$ & 2 \\
\hline
\end{tabular}


Table 3-4. (Continued)

\begin{tabular}{|c|c|c|c|c|c|c|}
\hline Medication & Country & $\begin{array}{l}\text { Medication } \\
\text { per model }\end{array}$ & $\begin{array}{c}\text { Average } \\
\text { medication } \\
\text { amount } \\
\text { per child } \\
\text { by country } \\
\end{array}$ & $\begin{array}{l}\text { Average } \\
\text { child for } \\
\text { the three } \\
\text { countries } \\
\text { (standard } \\
\text { deviation) }\end{array}$ & $\begin{array}{c}\text { Forecast of } \\
\text { medication } \\
\text { needed using } \\
\text { an average } \\
\text { from three } \\
\text { countries } \\
\end{array}$ & $\begin{array}{c}\text { Percent } \\
\text { difference }\end{array}$ \\
\hline \multirow{3}{*}{$\begin{array}{l}\text { Doxorubicin } \\
\text { (mg) }\end{array}$} & Tanzania & 48,906 & 39 & \multirow{3}{*}{$\begin{array}{l}41 \\
(2)\end{array}$} & 51,088 & -4 \\
\hline & Venezuela & 15,164 & 43 & & 14,715 & 3 \\
\hline & Honduras & 6,050 & 42 & & 5,952 & 2 \\
\hline \multirow{3}{*}{$\begin{array}{l}\text { Cyclophosphamide } \\
(\mathrm{mg})\end{array}$} & Tanzania & 652,085 & 528 & \multirow{3}{*}{$\begin{array}{l}549 \\
(26)\end{array}$} & 678,976 & -4 \\
\hline & Venezuela & 202,182 & 568 & & 195,563 & 3 \\
\hline & Honduras & 80,671 & 560 & & 79,104 & 2 \\
\hline \multirow{3}{*}{$\begin{array}{l}\text { Cytarabine } \\
(\mathrm{mg})\end{array}$} & Tanzania & 391,251 & 312 & \multirow{3}{*}{$\begin{array}{l}330 \\
(16)\end{array}$} & 407,468 & -4 \\
\hline & Venezuela & 121,309 & 341 & & 117,361 & 3 \\
\hline & Honduras & 48,402 & 336 & & 47,472 & 2 \\
\hline
\end{tabular}

Notes: SIOP - International Society of Paediatric Oncology; ALL - Acute lymphoblastic leukemia; mg - Milligrams; IV - Intravenous 
Table 3-5. Forecasted quantities of each essential medication required to deliver the SIOP Adapted ALL Regimen Level 3

\begin{tabular}{|c|c|c|c|c|c|c|}
\hline Medication & Country & $\begin{array}{c}\text { Medication } \\
\text { per model }\end{array}$ & $\begin{array}{c}\text { Average } \\
\text { medication } \\
\text { amount } \\
\text { per child } \\
\text { by country }\end{array}$ & $\begin{array}{l}\text { Average } \\
\text { child for } \\
\text { the three } \\
\text { countries } \\
\text { (standard } \\
\text { deviation) }\end{array}$ & $\begin{array}{c}\text { Forecast of } \\
\text { medication } \\
\text { needed using } \\
\text { an average } \\
\text { from three } \\
\text { countries }\end{array}$ & $\begin{array}{l}\text { Percent } \\
\text { difference }\end{array}$ \\
\hline \multirow{3}{*}{$\begin{array}{l}\text { Prednisone } \\
(\mathrm{mg})\end{array}$} & Tanzania & $1,800,997$ & 1,457 & \multirow{3}{*}{$\begin{array}{l}1,524 \\
(59)\end{array}$} & $1,884,076$ & -4 \\
\hline & Venezuela & 558,406 & 1,569 & & 542,663 & 3 \\
\hline & Honduras & 222,804 & 1,547 & & 219,504 & 2 \\
\hline \multirow{3}{*}{$\begin{array}{l}\text { Vincristine } \\
(\mathrm{mg})\end{array}$} & Tanzania & 52,275 & 42 & \multirow{3}{*}{$\begin{array}{l}44 \\
(2)\end{array}$} & 54,796 & -5 \\
\hline & Venezuela & 16,208 & 46 & & 15,783 & 3 \\
\hline & Honduras & 6,467 & 45 & & 6,384 & 1 \\
\hline \multirow{3}{*}{$\begin{array}{l}\text { L-asparaginase } \\
\text { (international } \\
\text { units) }\end{array}$} & Tanzania & $93,155,028$ & 75,368 & \multirow{3}{*}{$\begin{array}{l}78,843 \\
(3,060)\end{array}$} & $97,450,360$ & -4 \\
\hline & Venezuela & $28,883,086$ & 81,132 & & $28,068,227$ & 3 \\
\hline & Honduras & $11,524,359$ & 80,030 & & $11,353,440$ & 2 \\
\hline \multirow{3}{*}{$\begin{array}{l}\text { Intrathecal } \\
\text { methotrexate } \\
(\mathrm{mg})\end{array}$} & Tanzania & 329,641 & 267 & \multirow{3}{*}{$\begin{array}{r}267 \\
(1)\end{array}$} & 329,600 & 0 \\
\hline & Venezuela & 95,072 & 267 & & 94,933 & 0 \\
\hline & Honduras & 38,307 & 266 & & 38,400 & 0 \\
\hline \multirow{3}{*}{$\begin{array}{l}\text { Methotrexate oral } \\
\text { (mg) }\end{array}$} & Tanzania & $1,813,418$ & 1,467 & \multirow{3}{*}{$\begin{array}{c}1,535 \\
(60)\end{array}$} & $1,896,848$ & -4 \\
\hline & Venezuela & 562,257 & 1,579 & & 546,341 & 3 \\
\hline & Honduras & 224,341 & 1,558 & & 220,992 & 2 \\
\hline \multirow{3}{*}{$\begin{array}{l}\text { Methotrexate IV } \\
(\mathrm{mg})\end{array}$} & Tanzania & 103,506 & 84 & \multirow{3}{*}{$\begin{array}{l}88 \\
(3)\end{array}$} & 108,356 & -4 \\
\hline & Venezuela & 32,092 & 90 & & 31,209 & 3 \\
\hline & Honduras & 12,805 & 89 & & 12,624 & 1 \\
\hline \multirow{3}{*}{$\begin{array}{l}\text { Dexamethasone } \\
(\mathrm{mg})\end{array}$} & Tanzania & 946,041 & 765 & \multirow{3}{*}{$\begin{array}{l}801 \\
(31)\end{array}$} & 989,624 & -4 \\
\hline & Venezuela & 293,324 & 824 & & 285,037 & 3 \\
\hline & Honduras & 117,036 & 813 & & 115,296 & 2 \\
\hline $\begin{array}{l}\text { Mercaptopurine } \\
\text { (mg) }\end{array}$ & $\begin{array}{l}\text { Tanzania } \\
\text { Venezuela } \\
\text { Honduras }\end{array}$ & $\begin{array}{c}13,119,333 \\
4,067,701 \\
1,623,014\end{array}$ & $\begin{array}{l}10,614 \\
11,426 \\
11,271\end{array}$ & $\begin{array}{c}11,104 \\
(431)\end{array}$ & $\begin{array}{c}13,724,132 \\
3,952,905 \\
1,598,928\end{array}$ & $\begin{array}{l}-4 \\
3 \\
2\end{array}$ \\
\hline
\end{tabular}


Table 3-5. (Continued)

\begin{tabular}{|c|c|c|c|c|c|c|}
\hline Medication & Country & $\begin{array}{l}\text { Medication } \\
\text { per model }\end{array}$ & $\begin{array}{c}\text { Average } \\
\text { medication } \\
\text { amount } \\
\text { per child } \\
\text { by country }\end{array}$ & $\begin{array}{l}\text { Average } \\
\text { child for } \\
\text { the three } \\
\text { countries } \\
\text { (standard } \\
\text { deviation) }\end{array}$ & $\begin{array}{c}\text { Forecast of } \\
\text { medication } \\
\text { needed using } \\
\text { an average } \\
\text { from three } \\
\text { countries }\end{array}$ & $\begin{array}{c}\text { Percent } \\
\text { difference }\end{array}$ \\
\hline \multirow{3}{*}{$\begin{array}{l}\text { Doxorubicin } \\
\text { (mg) }\end{array}$} & Tanzania & 77,629 & 63 & \multirow{3}{*}{$\begin{array}{l}66 \\
(3)\end{array}$} & 81,576 & -5 \\
\hline & Venezuela & 24,069 & 68 & & 23,496 & 2 \\
\hline & Honduras & 9,604 & 67 & & 9,504 & 1 \\
\hline \multirow{3}{*}{$\begin{array}{l}\text { Cyclophosphamide } \\
\text { (mg) }\end{array}$} & Tanzania & $2,339,226$ & 1,893 & \multirow{3}{*}{$\begin{array}{c}1,980 \\
(77)\end{array}$} & $2,447,280$ & -4 \\
\hline & Venezuela & 725,286 & 2,037 & & 704,880 & 3 \\
\hline & Honduras & 289,389 & 2,010 & & 285,120 & 1 \\
\hline \multirow{3}{*}{$\begin{array}{l}\text { Cytarabine } \\
(\mathrm{mg})\end{array}$} & Tanzania & $1,403,536$ & 1,136 & \multirow{3}{*}{$\begin{array}{c}1,165 \\
(50)\end{array}$} & $1,439,528$ & -3 \\
\hline & Venezuela & 435,172 & 1,222 & & 414,621 & 5 \\
\hline & Honduras & 173,634 & 1,136 & & 167,712 & 4 \\
\hline
\end{tabular}

Notes: SIOP - International Society of Paediatric Oncology; ALL - Acute lymphoblastic leukemia; mg - Milligrams; IV - Intravenous 
Table 3-6. Doses of essential medication required per SIOP Adapted ALL Protocol Regimens

\begin{tabular}{|c|c|c|c|c|c|c|c|}
\hline \multirow[b]{2}{*}{ Medication } & \multirow[b]{2}{*}{ Dosage } & \multicolumn{3}{|c|}{ Regimen } & \multirow{2}{*}{$\begin{array}{c}\text { Regimen } \\
2 \text { CRT } \\
\text { doses }\end{array}$} & \multirow[b]{2}{*}{$\begin{array}{c}\text { Regimen } \\
3 \text { doses }\end{array}$} & \multirow[b]{2}{*}{$\begin{array}{c}\text { Regimen } \\
4 \text { doses }\end{array}$} \\
\hline & & $\begin{array}{c}\text { Regimen } \\
1 \text { doses }\end{array}$ & $\begin{array}{c}\text { 1 CRT } \\
\text { doses }\end{array}$ & $\begin{array}{c}\text { Regimen } \\
2 \text { doses }\end{array}$ & & & \\
\hline Prednisone & $40 \mathrm{mg} / \mathrm{m}^{2} /$ day & 22 & 22 & 0 & 0 & 0 & 0 \\
\hline Prednisone & $60 \mathrm{mg} / \mathrm{m}^{2 /}$ day & 7 & 7 & 29 & 29 & 29 & 29 \\
\hline Vincristine & $1.5 \mathrm{mg} / \mathrm{m}^{2}$ & 35 & 35 & 34 & 34 & 33 & 36 \\
\hline L-asparaginase & $6000 \mathrm{IU} / \mathrm{m}^{2}$ & 9 & 9 & 15 & 15 & 15 & 15 \\
\hline Methotrexate & IT & 20 & 16 & 22 & 18 & 23 & 19 \\
\hline Methotrexate & $20 \mathrm{mg} / \mathrm{m}^{2}$ & 106 & 110 & 92 & 96 & 92 & 48 \\
\hline Methotrexate & $200 \mathrm{mg}$ IV & 0 & 0 & 0 & 0 & 0 & 5 \\
\hline Dexamethasone & $6 \mathrm{mg} / \mathrm{m}^{2} /$ day & 150 & 150 & 130 & 130 & 130 & 120 \\
\hline Dexamethasone & $10 \mathrm{mg} / \mathrm{m}^{2} /$ day & & & 14 & 14 & 14 & 14 \\
\hline Mercaptopurine & $60 \mathrm{mg} / \mathrm{m}^{2}$ & 0 & 0 & 15 & 15 & 15 & 15 \\
\hline Mercaptopurine & $75 \mathrm{mg} / \mathrm{m}^{2}$ & 868 & 868 & 750 & 750 & 760 & 672 \\
\hline Doxorubicin & $25 \mathrm{mg} / \mathrm{m}^{2}$ & 0 & 0 & 3 & 3 & 3 & 3 \\
\hline Cyclophosphamide & $1000 \mathrm{mg} / \mathrm{m}^{2}$ & 0 & 0 & 1 & 1 & 3 & 3 \\
\hline
\end{tabular}


Table 3-6. (Continued)

\begin{tabular}{lccccccc}
\hline & Regimen & $\begin{array}{c}\text { Regimen } \\
\text { 1 CRT } \\
\text { Medication }\end{array}$ & Dosage & $\begin{array}{c}\text { Regimen } \\
\text { 1 doses }\end{array}$ & $\begin{array}{c}\text { Regimen } \\
\text { 2 CRT } \\
\text { doses }\end{array}$ & $\begin{array}{c}\text { Regimen } \\
\text { 3 doses }\end{array}$ & $\begin{array}{c}\text { Regimen } \\
\text { 4 doses }\end{array}$ \\
\hline Cytarabine & $75 \mathrm{mg} / \mathrm{m}^{2}$ & 0 & 0 & 8 & 8 & 24 & 24 \\
\hline
\end{tabular}

Notes: SIOP - International Society of Paediatric Oncology; ALL - Acute lymphoblastic leukemia; CRT - Cranial irradiation; mg - milligrams; $\mathrm{M}^{2}$ - Square meter; IU - International Units; IT - Intrathecal; IV - Intravenous 


\section{Discussion}

\section{Summary of Findings and Strengths}

This study described a forecasting model that utilizes publicly available data to estimate the quantity of essential chemotherapy needed for a child diagnosed with ALL. The goal of the UN World Populations Prospects is to provide accurate and timely population data for all countries (United Nations, 2019). WHO and CDC growth charts can be used for any countryspecific initial forecasts, and country-specific ALL incidence rates do not differ dramatically from SEER incidence rates (Allemani et al.; Centers for Disease Control and Prevention, 2010; Katz et al., 2015). The SIOP Adapted ALL regimens are appropriate for all countries (Hunger et al., 2009). Understanding essential chemotherapy requirements for each regimen allows appropriate modifications of practice during times of shortages.

\section{Implications for Practice}

Our forecasting model can be of value to policy makers and healthcare providers. The forecasting model estimates the incidence of ALL and the amount of essential chemotherapy required to treat this burden. Policy makers can use this information to budget and secure the appropriate amount of essential chemotherapy within their country. Maintaining disciplined inventory levels could provide advance warnings of shortages so additional or alternative suppliers could be sourced to potentially mitigate or prevent shortages. Providers can ensure their treatment centers have an adequate supply of essential chemotherapy to treat their estimated incidence of ALL.

\section{Limitations}

Using surrogate measures of ALL incidence and growth curves to calculate doses by age and imputed percentages of each ALL risk group may introduce error in estimated chemotherapy needs. Furthermore, the UN World Populations Prospects is based upon population estimates and projections rather than the actual population, which may introduce an additional degree of error (United Nations, 2019). Patient-level data address all of these weaknesses since they directly measure incidence, rely on measurement of patients' actual height and weight rather than estimates from population curves, and take into account the treatment regimen used. However, these are not always available in LMIC where forecasting models could provide the greatest assistance. The publicly available databases used in this study do, however, provide sound forecasts for countries, regions, and centers which currently have little basis upon which to stock essential chemotherapies. Information systems are also available at no cost (e.g., www.ResonanceOncology.org) to facilitate such direct measurements and automatically calculate a patient's forecasted need prospectively as well as actual chemotherapy received by documenting each dose in the system-generated, individualized chemotherapy roadmap. 
Non-specific country standard growth charts were used in calculating chemotherapy predictions and may introduce error in the estimated need. The WHO and CDC growth curves are standardized and widely utilized. However, values for children in each country inevitably differ and can even vary by regions or ethnic groups within the same country. In addition to these expected variations, we suspect that the WHO and CDC growth curves for children in LMIC, in particular, may overestimate chemotherapy needs (de Onis et al., 2010; Poskitt, 2014). For example, the WHO reported higher obesity among children in the US and more growth-stunting in LMIC, which could lead to underestimation of chemotherapy needed for children in the US and overestimation for those in LMIC (World Health Organization, 2018). Where age-specific obesity rates are known, the model could be refined, or ideally, individual patient data could be used to create accurate forecasts by patient, center, region, and country.

\section{Future Directions - ALL Essential Chemotherapy Multipliers}

Comparison of the average quantity of essential chemotherapy for each of the three countries yielded an interesting finding. It may be possible to produce a standard populationbased multiplier for each essential chemotherapy, as shown in the Appendix for a single ALL regimen. This could allow a country or treatment center to estimate their need for each essential chemotherapy for each cancer type and regimen.

This forecasting required age-standardized incidence rates, growth curves, imputed risk stratification, and census data. Additional forecasting could be done by cancer type, chemotherapy agent, and at any level of society (individual, hospital, city, state, nation, or world). Such models can inform health policy in a manner that could facilitate access to the essential chemotherapy required and thereby eliminate needless deaths from curable cancers due to the unavailability of low-cost, essential drugs.

Forecasting national needs for essential chemotherapies for ALL is feasible using existing public data sources. Simplifying the forecasting model and applying it to a wider variety of regimens in a larger range of countries will set the stage for universal continuous supplies of essential cancer medicines. Detailed forecasting at the individual, cancer center, and regional level requires an information system with patient-level data, which can also be used to reduce other causes of preventable treatment failure like misdiagnosis, abandonment, and toxic death.

\section{Conclusion}

We found forecasting the maximum quantity of essential chemotherapies for ALL was feasible using our model, based on existing public data sources. This finding allows stakeholders including providers, cancer centers, hospitals, countries, and drug manufacturers to estimate the essential chemotherapies and to strategically manage the purchasing and inventory to treat ALL. Such knowledge may be critical to prevent or mitigate drug shortages. The model is practical and can be applied to other cancer types and treatment protocols. 


\section{CHAPTER 4. UTILIZING MULTIPLIERS TO FORECAST ESSENTIAL CHEMOTHERAPY FOR TREATMENT OF ACUTE LYMPHOBLASTIC LEUKEMIA IN CHILDREN AND ADOLESCENTS RESIDING IN LOW- AND MIDDLE-INCOME COUNTRIES}

\section{Introduction}

Acute lymphoblastic leukemia (ALL) is the most common pediatric cancer, with contemporary therapy resulting in an $85 \%$ 5-year, event-free survival and $90 \%$ overall survival in high-income countries (HIC) (Cooper \& Brown, 2015; Essig et al., 2014; Jaime-Perez et al., 2016; Jeha et al., 2019). An estimated $89 \%$ of the world's children live in low- and middleincome countries (LMIC) where ALL cure rates are much lower (Allemani et al., 2015; Bhakta et al., 2013; Cooper \& Brown, 2015; Jabbour et al., 2018; Jaime-Perez et al., 2016; Lam et al., 2019; Magrath et al., 2013; Pribnow et al., 2017; Redaniel et al., 2010). Causes of mortality in LMIC include non-diagnosis, incorrect or delayed diagnosis, unaffordability, abandonment and refusal of treatment, toxic death, and relapse. Preventable treatment failure may be directly related to lack of essential chemotherapy (Howard et al., 2017; Howard et al., 2007; Hsu et al., 2007; Lam et al., 2019; Simonyan et al., 2019).

The absence of accurate forecasting of essential chemotherapy demand in LMIC has been identified as a key contributor to the lack of access healthcare (Pisa \& McCurdy, 2019). Rarely is disease incidence utilized in calculating the demand for essential chemotherapy (Denburg et al., 2014). A previously described forecasting model may be utilized in estimating essential chemotherapy in the treatment of childhood ALL by patient and population multipliers. First, the forecasting model incorporates available source data including incidence and body surface area by age, risk group stratification, and treatment protocols for a given country, providing an essential chemotherapy estimation (Centers for Disease Control and Prevention, 2010; Hunger et al., 2009; Moricke et al., 2010; National Institutes of Health, 2010). The patient multiplier is a given number that can be multiplied by any number of children 0-19 years of age with ALL to estimate their needed essential chemotherapy for treatment. The population multiplier is a given number that can be multiplied by a population of children 0-19 years of age to estimate the needed essential chemotherapy for the projected incidence of pediatric ALL. The aim of this study was to determine if the multipliers may be accurately derived from the forecasting model in estimating essential chemotherapy as well as determine the margin of error. This forecasting model and multiplier was applied in calculating essential chemotherapy as per the SIOP ALL treatment regimens by the annual pediatric ALL incidence rate.

\section{Methods}

\section{Multipliers and Comparisons to Forecast Model}

The forecasting multipliers were developed by a hypothetical population of $10,000,000$ children evenly distributed (2.5 million each) across four 5-year interval age cohorts (0-4, 5-9, 
10-14, and 15-19 years) calculated by the forecasting model projection. Patient multipliers were calculated by dividing the total chemotherapy dosage required to treat the projected ALL incidence by population (354). Population multipliers were calculated by dividing total $\mathrm{mg}$ of the given chemotherapy required to treat the population by the population $(10,000,000)$.

\section{Comparison of Outliers of Extreme Population Distributions}

The forecasting model and multipliers were then applied to 171 countries with agespecific population data available in the United Nations 2017 World Populations Prospects (United Nations, 2019). Results from the forecasting model and multipliers were compared to determine differences for each country and for countries with extreme population distributions across the pediatric age range. Extreme population distributions were defined as countries with 1 or 2 standard deviations from the mean of the weighted body surface area of the 171 nations, countries with the greatest percentage of children in the 0-4 age cohort, and countries with the greatest percentage of children in the 15-19 age cohort.

Brazil was 1 standard deviation from the mean of the weighted body surface area of the 171 nations and was utilized to determine the differences between the multipliers and forecasting model for countries 1 standard deviation from the mean of the weighted body surface.

Kazakhstan was 2 standard deviations from the mean of the weighted body surface area of the 171 nations and was utilized to determine the difference between the multipliers and forecasting model for countries 2 standard deviations from the mean of the weighted body surface area. Niger had the greatest percentage of children within the 0-4 age cohort and was utilized to determine the difference between the multipliers and forecasting model for countries with the greatest percentage of children in the 0-4 age cohort. Albania had the greatest percentage of children within the 15-19 age cohort and was utilized to determine the difference between the multipliers and forecasting model for countries with the greatest percentage of children within the 15-19 age cohort.

\section{Maximum and Minimum Estimates}

Maximum chemotherapy estimates assume completed treatment of pediatric ALL according to the SIOP Adapted ALL Treatment Regimens. Minimum estimates assume treatment failures secondary to incorrect or delayed diagnosis, unaffordability, abandonment and refusal of treatment, and relapse based upon a country's World Bank categorization. The World Bank defines a gross national income per capita below $\$ 1,025$ as LIC, between $\$ 1,026$ and $\$ 3995$ as LMIC, and between $\$ 3,996$ and $\$ 12,375$ as UMIC (World Bank, 2018). Minimum estimates for low-income countries assume a utilization of $26 \%$ of the total maximum estimate of the essential chemotherapies. Minimum estimates for lower middle-income countries assume a utilization of $34 \%$ of the total maximum estimate of the essential chemotherapies. Minimum estimates for upper middle-income countries assume $62 \%$ of the total maximum estimate of the essential chemotherapies. 


\section{Shelf Life and Storage Requirements}

Shelf life and storage requirements were based upon prescribing information from the United States Food and Drug Administration (FDA), the United Kingdom Medicines and Healthcare products Regulatory Agency (MHRA), and the European Medicines Agency (EMA).

\section{Results}

Brazil demonstrated the difference between the multipliers and forecasting model at 1 standard deviation from the mean of the weighted body surface area of 171 nations (Tables 4-1 to 4-4). On two analyses, the multipliers demonstrated a greater than $2 \%$ difference from the forecasting model. At a level 1 treatment center with cranial radiation as a treatment component, the multiplier demonstrated a 3\% less need for oral methotrexate than the forecasting model. At a level 3 treatment center with cranial radiation as a treatment component, the multiplier demonstrated a $4 \%$ greater need for vincristine than the forecasting model. Kazakhstan demonstrated the difference between the multipliers and forecasting model at 2 standard deviations from the mean of the weighted body surface area of the 171 nations (Tables 4-1 to 44). There were 4 times when the multipliers demonstrated greater than a $10 \%$ difference from the forecasting model. At a level 1 treatment center with and without cranial radiation, the multiplier demonstrated a $12 \%$ greater need for vincristine than the forecasting model. At a level 2 treatment center, the multiplier demonstrated a $13 \%$ greater need for vincristine than the forecasting model. At a level 3 treatment center, the multiplier demonstrated a $15 \%$ greater need for vincristine than the forecasting model.

Niger demonstrated the difference between the multipliers and the forecasting model for the country with the greatest percentage of children in the $0-4$ age cohort at $34 \%$ (Tables 4-1 to 4-4). Vincristine was the only chemotherapy agent that had a greater than $10 \%$ difference for the multipliers and the forecasting model for Niger. At a level 1 treatment center with and without cranial radiation as a treatment component, the multiplier demonstrated a $12 \%$ greater need for vincristine than the forecasting model. At a level 2 treatment center, the multiplier demonstrated a 13\% greater need for vincristine than the forecasting model. At a level 3 treatment center, the multiplier demonstrated a $15 \%$ greater need for vincristine than the forecasting model. Albania showed a difference between the multipliers and forecasting model for the country with the greatest percentage of children in the 15-19 age cohort at 32\% (Tables 4-1 to 4-4). There were 2 times when multipliers demonstrated greater than a $6 \%$ difference from the forecasting model. At a level 1 treatment center with and without cranial radiation as a treatment component, the multiplier demonstrated a $12 \%$ less need for vincristine than the forecasting model.

Minimum and maximum multipliers for LIC, LMIC, and UMIC for each essential chemotherapy administered in the 3 described treatment centers per SIOP ALL adapted treatment regimens are depicted in Tables 4-5 to 4-8 and shelf life and storage requirements for each essential chemotherapy (Table 4-9). Three chemotherapy agents require cold chain storage: L-asparaginase, oral methotrexate, and doxorubicin. Methotrexate and cytarabine oral solution have the shortest shelf life at 18 months. Additionally, methotrexate and mercaptopurine tablets both have the longest shelf life at 60 months. 
Table 4-1. Difference between the multipliers and forecasting model for International Society of Paediatric Oncology Adapted Acute Lymphoblastic Leukemia Regimen Level 1 without cranial radiation in selected countries that represent extremes of age distribution

\begin{tabular}{|c|c|c|c|c|c|}
\hline \multirow[b]{2}{*}{ Medication dosage } & \multirow[b]{2}{*}{$\begin{array}{l}\text { Reason for } \\
\text { selection }\end{array}$} & Brazil & Kazakhstan & Niger & Albania \\
\hline & & $\begin{array}{l}\text { One standard } \\
\text { deviation more } \\
\text { than the mean } \\
\text { weighted BSA }\end{array}$ & $\begin{array}{l}\text { Two standard } \\
\text { deviations less } \\
\text { than the mean } \\
\text { weighted BSA }\end{array}$ & $\begin{array}{c}\text { Greatest } \\
\text { percentage } \\
\text { of children } \\
\text { aged } 0-4 \\
\text { years }\end{array}$ & $\begin{array}{c}\text { Greatest } \\
\text { percentage } \\
\text { of children } \\
\text { aged } 15-19 \\
\text { years } \\
\end{array}$ \\
\hline \multirow{3}{*}{$\begin{array}{l}\text { Prednisone } \\
\text { milligrams }\end{array}$} & \multirow{3}{*}{$\begin{array}{c}\text { Multiplier } \\
\text { model } \\
\% \text { diff }\end{array}$} & $2,532,464$ & 271,583 & 555,901 & 29,807 \\
\hline & & $2,595,522$ & 246,814 & 504,493 & 31,518 \\
\hline & & $2 \%$ & $-9 \%$ & $-9 \%$ & $6 \%$ \\
\hline \multirow{3}{*}{$\begin{array}{l}\text { Vincristine } \\
\text { milligrams }\end{array}$} & \multirow{3}{*}{$\begin{array}{l}\text { Multiplier } \\
\text { model } \\
\% \text { diff }\end{array}$} & 105,245 & 11,287 & 23,102 & 1,239 \\
\hline & & 103,521 & 9,960 & 20,222 & 1,382 \\
\hline & & $-2 \%$ & $-12 \%$ & $-12 \%$ & $12 \%$ \\
\hline \multirow{3}{*}{$\begin{array}{l}\text { L-asparaginase } \\
\text { (international units) }\end{array}$} & \multirow{3}{*}{$\begin{array}{l}\text { Multiplier } \\
\text { model } \\
\% \text { diff }\end{array}$} & $105,197,014$ & $11,281,393$ & $23,091,810$ & $1,238,157$ \\
\hline & & $107,814,004$ & $10,252,286$ & $20,955,876$ & $1,309,203$ \\
\hline & & $2 \%$ & $-9 \%$ & $-9 \%$ & $6 \%$ \\
\hline \multirow{3}{*}{$\begin{array}{l}\text { Intrathecal } \\
\text { methotrexate } \\
\text { milligrams }\end{array}$} & \multirow{3}{*}{$\begin{array}{l}\text { Multiplier } \\
\text { model } \\
\% \text { diff }\end{array}$} & 526,226 & 56,433 & 115,512 & 6,194 \\
\hline & & 526,226 & 56,433 & 115,512 & 6,194 \\
\hline & & $0 \%$ & $0 \%$ & $0 \%$ & \\
\hline \multirow{3}{*}{$\begin{array}{l}\text { Methotrexate oral } \\
\text { milligrams }\end{array}$} & \multirow{3}{*}{$\begin{array}{l}\text { Multiplier } \\
\text { model } \\
\% \text { diff }\end{array}$} & $4,130,876$ & 442,998 & 906,769 & 48,620 \\
\hline & & $4,232,698$ & 402,497 & 822,712 & 51,398 \\
\hline & & $2 \%$ & $-9 \%$ & $-9 \%$ & $6 \%$ \\
\hline
\end{tabular}


Table 4-1. (Continued)

\begin{tabular}{|c|c|c|c|c|c|}
\hline \multirow[b]{2}{*}{ Medication dosage } & \multirow[b]{2}{*}{$\begin{array}{c}\text { Reason for } \\
\text { selection }\end{array}$} & Brazil & Kazakhstan & Niger & Albania \\
\hline & & $\begin{array}{l}\text { One standard } \\
\text { deviation more } \\
\text { than the mean } \\
\text { weighted BSA }\end{array}$ & $\begin{array}{l}\text { Two standard } \\
\text { deviations less } \\
\text { than the mean } \\
\text { weighted BSA }\end{array}$ & $\begin{array}{c}\text { Greatest } \\
\text { percentage } \\
\text { of children } \\
\text { aged } 0-4 \\
\text { years }\end{array}$ & $\begin{array}{c}\text { Greatest } \\
\text { percentage } \\
\text { of children } \\
\text { aged } 15-19 \\
\text { years }\end{array}$ \\
\hline \multirow{3}{*}{$\begin{array}{l}\text { Dexamethasone } \\
\text { milligrams }\end{array}$} & \multirow{3}{*}{$\begin{array}{l}\text { Multiplier } \\
\text { model } \\
\% \text { diff }\end{array}$} & $1,754,088$ & 188,109 & 385,040 & 20,645 \\
\hline & & $1,796,900$ & 170,871 & 349,265 & 21,820 \\
\hline & & $2 \%$ & $-9 \%$ & $-9 \%$ & $6 \%$ \\
\hline \multirow{3}{*}{$\begin{array}{l}\text { Mercaptopurine } \\
\text { milligrams }\end{array}$} & \multirow{3}{*}{$\begin{array}{l}\text { Multiplier } \\
\text { model } \\
\% \text { diff }\end{array}$} & $126,820,528$ & $13,600,312$ & $27,838,390$ & $1,492,663$ \\
\hline & & $129,975,771$ & $12,359,700$ & $25,263,473$ & $1,578,316$ \\
\hline & & $2 \%$ & $-9 \%$ & $-9 \%$ & $6 \%$ \\
\hline
\end{tabular}

Notes: BSA - Body surface area. Weighted BSA, based upon age distribution. Multiplier, Nations' estimated incidence of acute lymphoblastic leukemia was multiplied by the individual patient multiplier. Model, Each nation's drug requirement was estimated via the full predictive model. Intrathecal methotrexate, doses were rounded to $12 \mathrm{mg}$. 
Table 4-2. Difference between the multipliers and forecasting model for International Society of Paediatric Oncology Adapted Acute Lymphoblastic Leukemia Regimen Level 1 with cranial radiation in selected countries that represent extremes of age distribution

\begin{tabular}{|c|c|c|c|c|c|}
\hline Medication dosage & $\begin{array}{l}\text { Reason for } \\
\text { selection }\end{array}$ & $\begin{array}{c}\text { One standard } \\
\text { deviation more } \\
\text { than the mean } \\
\text { weighted BSA }\end{array}$ & $\begin{array}{l}\text { Kazakhstan } \\
\text { Two standard } \\
\text { deviations less } \\
\text { than the mean } \\
\text { weighted BSA }\end{array}$ & $\begin{array}{c}\text { Niger } \\
\text { Greatest } \\
\text { percentage } \\
\text { of children } \\
\text { aged 0-4 } \\
\text { years }\end{array}$ & $\begin{array}{c}\text { Albania } \\
\text { Greatest } \\
\text { percentage } \\
\text { of children } \\
\text { aged 15-19 } \\
\text { years } \\
\end{array}$ \\
\hline $\begin{array}{l}\text { Prednisone } \\
\text { milligrams }\end{array}$ & $\begin{array}{l}\text { Multiplier } \\
\text { model } \\
\% \text { diff }\end{array}$ & $\begin{array}{c}2,532,464 \\
2,595,522 \\
2 \%\end{array}$ & $\begin{array}{c}271,583 \\
246,814 \\
-9 \%\end{array}$ & $\begin{array}{c}555,901 \\
504,493 \\
-9 \%\end{array}$ & $\begin{array}{c}29,807 \\
31,518 \\
6 \%\end{array}$ \\
\hline $\begin{array}{l}\text { Vincristine } \\
\text { milligrams }\end{array}$ & $\begin{array}{l}\text { Multiplier } \\
\text { model } \\
\% \text { diff }\end{array}$ & $\begin{array}{c}105,245 \\
103,521 \\
-2 \%\end{array}$ & $\begin{array}{c}11,287 \\
9,960 \\
-12 \%\end{array}$ & $\begin{array}{c}23,102 \\
20,222 \\
-12 \%\end{array}$ & $\begin{array}{c}1,239 \\
1,382 \\
12 \%\end{array}$ \\
\hline $\begin{array}{l}\text { L-asparaginase } \\
\text { (international units) }\end{array}$ & $\begin{array}{l}\text { Multiplier } \\
\text { model } \\
\% \text { diff }\end{array}$ & $\begin{array}{c}105,197,014 \\
107,814,004 \\
2 \%\end{array}$ & $\begin{array}{c}11,281,393 \\
10,252,286 \\
-9 \%\end{array}$ & $\begin{array}{c}23,091,810 \\
20,955,876 \\
-9 \%\end{array}$ & $\begin{array}{c}1,238,157 \\
1,309,203 \\
6 \%\end{array}$ \\
\hline $\begin{array}{l}\text { Intrathecal } \\
\text { methotrexate } \\
\text { milligrams }\end{array}$ & $\begin{array}{l}\text { Multiplier } \\
\text { model } \\
\% \text { diff }\end{array}$ & $\begin{array}{c}460,448 \\
459,922 \\
0 \%\end{array}$ & $\begin{array}{c}49,379 \\
49,322 \\
0 \%\end{array}$ & $\begin{array}{c}101,073 \\
100,957 \\
0 \%\end{array}$ & $\begin{array}{c}5,413 \\
5,413 \\
0 \%\end{array}$ \\
\hline $\begin{array}{l}\text { Methotrexate oral } \\
\text { milligrams }\end{array}$ & $\begin{array}{l}\text { Multiplier } \\
\text { model } \\
\% \text { diff }\end{array}$ & $\begin{array}{c}4,227,351 \\
4,333,324 \\
3 \%\end{array}$ & $\begin{array}{c}453,344 \\
412,066 \\
-9 \%\end{array}$ & $\begin{array}{c}927,946 \\
842,271 \\
-9 \%\end{array}$ & $\begin{array}{c}49,755 \\
52,620 \\
6 \%\end{array}$ \\
\hline
\end{tabular}


Table 4-2. (Continued)

\begin{tabular}{|c|c|c|c|c|c|}
\hline \multirow[b]{2}{*}{ Medication dosage } & \multirow[b]{2}{*}{$\begin{array}{c}\text { Reason for } \\
\text { selection }\end{array}$} & Brazil & Kazakhstan & Niger & Albania \\
\hline & & $\begin{array}{l}\text { One standard } \\
\text { deviation more } \\
\text { than the mean } \\
\text { weighted BSA }\end{array}$ & $\begin{array}{l}\text { Two standard } \\
\text { deviations less } \\
\text { than the mean } \\
\text { weighted BSA }\end{array}$ & $\begin{array}{c}\text { Greatest } \\
\text { percentage of } \\
\text { children aged } \\
0-4 \text { years }\end{array}$ & $\begin{array}{c}\text { Greatest } \\
\text { percentage } \\
\text { of children } \\
\text { aged } 15-19 \\
\text { years }\end{array}$ \\
\hline \multirow{3}{*}{$\begin{array}{l}\text { Dexamethasone } \\
\text { milligrams }\end{array}$} & Multiplier & $1,754,088$ & 188,109 & 385,040 & 20,645 \\
\hline & model & $1,796,900$ & 170,871 & 349,265 & 21,820 \\
\hline & $\%$ diff & $2 \%$ & $-9 \%$ & $-9 \%$ & $6 \%$ \\
\hline \multirow{3}{*}{$\begin{array}{l}\text { Mercaptopurine } \\
\text { milligrams }\end{array}$} & Multiplier & $126,820,528$ & $13,600,312$ & $27,838,390$ & $1,492,663$ \\
\hline & model & $129,975,771$ & $12,359,700$ & $25,263,473$ & $1,578,316$ \\
\hline & $\%$ diff & $2 \%$ & $-9 \%$ & $-9 \%$ & $6 \%$ \\
\hline
\end{tabular}

Notes: BSA - Body surface area. Weighted BSA, based upon age distribution. Multiplier, Nations' estimated incidence of acute lymphoblastic leukemia was multiplied by the individual patient multiplier. Model, each nation's drug requirement was estimated via the full predictive model. For Intrathecal methotrexate, doses were rounded to $12 \mathrm{mg}$. 
Table 4-3. Difference between the multipliers and forecasting model for International Society of Paediatric Oncology Adapted Acute Lymphoblastic Leukemia Regimen Level 2 in selected countries that represent extremes of age distribution

\begin{tabular}{|c|c|c|c|c|c|}
\hline Medication dosage & $\begin{array}{c}\text { Reason } \\
\text { for } \\
\text { selection } \\
\end{array}$ & $\begin{array}{c}\text { Brazil } \\
\text { standard } \\
\text { deviation more } \\
\text { than the mean } \\
\text { weighted BSA }\end{array}$ & $\begin{array}{c}\text { Kazakhstan } \\
2 \text { standard } \\
\text { deviations less } \\
\text { than the mean } \\
\text { weighted BSA }\end{array}$ & $\begin{array}{c}\text { Niger } \\
\text { Greatest } \\
\text { percentage of } \\
\text { children aged } \\
0-4 \text { years } \\
\end{array}$ & $\begin{array}{c}\text { Albania } \\
\text { Greatest } \\
\text { percentage of } \\
\text { children aged } \\
15-19 \text { years } \\
\end{array}$ \\
\hline $\begin{array}{l}\text { Prednisone } \\
\text { milligrams }\end{array}$ & $\begin{array}{l}\text { Multiplier } \\
\text { model } \\
\% \text { diff }\end{array}$ & $\begin{array}{c}3,091,579 \\
3,148,968 \\
2 \%\end{array}$ & $\begin{array}{c}331,543 \\
299,443 \\
-10 \%\end{array}$ & $\begin{array}{c}678,633 \\
612,067 \\
-10 \%\end{array}$ & $\begin{array}{c}36,388 \\
38,238 \\
5 \%\end{array}$ \\
\hline $\begin{array}{l}\text { Vincristine } \\
\text { milligrams }\end{array}$ & $\begin{array}{l}\text { Multiplier } \\
\text { model } \\
\% \text { diff }\end{array}$ & $\begin{array}{c}105,245 \\
102,932 \\
-2 \%\end{array}$ & $\begin{array}{c}11,287 \\
9,788 \\
-13 \%\end{array}$ & $\begin{array}{c}23,102 \\
20,007 \\
-13 \%\end{array}$ & $\begin{array}{c}1,239 \\
1,250 \\
1 \%\end{array}$ \\
\hline $\begin{array}{l}\text { L-asparaginase } \\
\text { (international units) }\end{array}$ & $\begin{array}{l}\text { Multiplier } \\
\text { model } \\
\% \text { diff }\end{array}$ & $\begin{array}{c}149,378,094 \\
153,095,885 \\
2 \%\end{array}$ & $\begin{array}{c}16,019,399 \\
14,558,246 \\
-9 \%\end{array}$ & $\begin{array}{c}32,790,004 \\
29,757,344 \\
-9 \%\end{array}$ & $\begin{array}{c}1,758,163 \\
1,859,068 \\
6 \%\end{array}$ \\
\hline $\begin{array}{l}\text { Intrathecal } \\
\text { methotrexate } \\
\text { milligrams }\end{array}$ & $\begin{array}{l}\text { Multiplier } \\
\text { model } \\
\% \text { diff }\end{array}$ & $\begin{array}{c}548,152 \\
548,854 \\
0 \%\end{array}$ & $\begin{array}{c}58,784 \\
58,859 \\
0 \%\end{array}$ & $\begin{array}{c}120,325 \\
120,479 \\
0 \%\end{array}$ & $\begin{array}{c}6,452 \\
6,460 \\
0 \%\end{array}$ \\
\hline $\begin{array}{l}\text { Methotrexate Oral } \\
\text { milligrams }\end{array}$ & $\begin{array}{l}\text { Multiplier } \\
\text { model } \\
\% \text { diff }\end{array}$ & $\begin{array}{c}3,801,985 \\
3,896,478 \\
2 \%\end{array}$ & $\begin{array}{c}407,727 \\
370,525 \\
-9 \%\end{array}$ & $\begin{array}{c}834,574 \\
757,361 \\
-9 \%\end{array}$ & $\begin{array}{c}44,749 \\
47,316 \\
6 \%\end{array}$ \\
\hline $\begin{array}{l}\text { Dexamethasone } \\
\text { milligrams }\end{array}$ & $\begin{array}{l}\text { Multiplier } \\
\text { model } \\
\% \text { diff }\end{array}$ & $\begin{array}{c}1,778,206 \\
1,822,057 \\
2 \%\end{array}$ & $\begin{array}{c}190,696 \\
173,264 \\
-9 \%\end{array}$ & $\begin{array}{c}390,334 \\
354,154 \\
-9 \%\end{array}$ & $\begin{array}{c}20,929 \\
22,126 \\
6 \%\end{array}$ \\
\hline
\end{tabular}


Table 4-3. (Continued)

\begin{tabular}{|c|c|c|c|c|c|}
\hline Medication dosage & $\begin{array}{c}\text { Reason } \\
\text { for } \\
\text { selection } \\
\end{array}$ & $\begin{array}{c}\text { Brazil } \\
\text { 1 standard } \\
\text { deviation more } \\
\text { than the mean } \\
\text { weighted BSA }\end{array}$ & $\begin{array}{c}\text { Kazakhstan } \\
2 \text { standard } \\
\text { deviations less } \\
\text { than the mean } \\
\text { weighted BSA } \\
\end{array}$ & $\begin{array}{c}\text { Niger } \\
\text { Greatest } \\
\text { percentage of } \\
\text { children aged } \\
0-4 \text { years } \\
\end{array}$ & $\begin{array}{c}\text { Albania } \\
\text { Greatest } \\
\text { percentage of } \\
\text { children aged } \\
15-19 \text { years }\end{array}$ \\
\hline $\begin{array}{l}\text { Mercaptopurine } \\
\text { milligrams }\end{array}$ & $\begin{array}{l}\text { Multiplier } \\
\text { model } \\
\% \text { diff }\end{array}$ & $\begin{array}{c}62,938,853 \\
64,505,717 \\
2 \%\end{array}$ & $\begin{array}{c}6,749,601 \\
6,134,000 \\
-9 \%\end{array}$ & $\begin{array}{c}13,815,715 \\
12,538,017 \\
-9 \%\end{array}$ & $\begin{array}{c}740,783 \\
783,303 \\
6 \%\end{array}$ \\
\hline $\begin{array}{l}\text { Doxorubicin } \\
\text { milligrams }\end{array}$ & $\begin{array}{l}\text { Multiplier } \\
\text { model } \\
\% \text { diff }\end{array}$ & $\begin{array}{c}92,090 \\
94,337 \\
2 \%\end{array}$ & $\begin{array}{c}9,876 \\
8,971 \\
-9 \%\end{array}$ & $\begin{array}{c}20,215 \\
18,336 \\
-9 \%\end{array}$ & $\begin{array}{c}1,084 \\
1,146 \\
6 \%\end{array}$ \\
\hline $\begin{array}{l}\text { Cyclophosphamide } \\
\text { milligrams }\end{array}$ & $\begin{array}{l}\text { Multiplier } \\
\text { model } \\
\% \text { diff }\end{array}$ & $\begin{array}{c}1,227,861 \\
1,257,830 \\
2 \%\end{array}$ & $\begin{array}{c}131,677 \\
119,610 \\
-9 \%\end{array}$ & $\begin{array}{c}269,528 \\
244,485 \\
-9 \%\end{array}$ & $\begin{array}{c}14,452 \\
15,274 \\
6 \%\end{array}$ \\
\hline $\begin{array}{l}\text { Cytarabine } \\
\text { milligrams }\end{array}$ & $\begin{array}{c}\text { Multiplier } \\
\text { model } \\
\% \text { diff } \\
\end{array}$ & $\begin{array}{c}736,717 \\
754,698 \\
2 \% \\
\end{array}$ & $\begin{array}{c}79,006 \\
71,766 \\
-9 \% \\
\end{array}$ & $\begin{array}{c}161,717 \\
146,691 \\
-9 \% \\
\end{array}$ & $\begin{array}{c}8,671 \\
9,164 \\
6 \% \\
\end{array}$ \\
\hline
\end{tabular}

Notes: BSA - Body surface area. Weighted BSA, based upon age distribution. Multiplier, Nations' estimated incidence of acute lymphoblastic leukemia was multiplied by the individual patient multiplier. Model, each nation's drug requirement was estimated via the full predictive model. For Intrathecal methotrexate, doses were rounded to $12 \mathrm{mg}$. 
Table 4-4. Difference between the multipliers and forecasting model for International Society of Paediatric Oncology Adapted Acute Lymphoblastic Leukemia Regimen Level 3 in selected countries that represent extremes of age distribution

\begin{tabular}{|c|c|c|c|c|c|}
\hline Medication dosage & $\begin{array}{l}\text { Reason for } \\
\text { selection }\end{array}$ & $\begin{array}{c}\text { Brazil } \\
\text { standard } \\
\text { deviation more } \\
\text { than the mean } \\
\text { weighted BSA }\end{array}$ & $\begin{array}{c}\text { Kazakhstan } \\
2 \text { standard } \\
\text { deviations less } \\
\text { than the mean } \\
\text { weighted BSA }\end{array}$ & $\begin{array}{c}\text { Niger } \\
\text { Greatest } \\
\text { percentage of } \\
\text { children aged } \\
\text { 0-4 years }\end{array}$ & $\begin{array}{c}\text { Albania } \\
\text { Greatest } \\
\text { percentage of } \\
\text { children aged } \\
15-19 \text { years }\end{array}$ \\
\hline $\begin{array}{l}\text { Prednisone } \\
\text { milligrams }\end{array}$ & $\begin{array}{l}\text { Multiplier } \\
\text { model } \\
\% \text { diff }\end{array}$ & $\begin{array}{c}3,389,774 \\
3,474,007 \\
2 \%\end{array}$ & $\begin{array}{c}363,521 \\
330,351 \\
-9 \%\end{array}$ & $\begin{array}{c}744,090 \\
675,245 \\
-9 \%\end{array}$ & $\begin{array}{c}39,897 \\
42,185 \\
6 \%\end{array}$ \\
\hline $\begin{array}{l}\text { Vincristine } \\
\text { milligrams }\end{array}$ & $\begin{array}{l}\text { Multiplier } \\
\text { model } \\
\% \text { diff }\end{array}$ & $\begin{array}{c}105,245 \\
100,836 \\
-4 \%\end{array}$ & $\begin{array}{c}11,287 \\
9,589 \\
-15 \%\end{array}$ & $\begin{array}{c}23,102 \\
19,600 \\
-15 \%\end{array}$ & $\begin{array}{c}6,890 \\
1,224 \\
-1 \%\end{array}$ \\
\hline $\begin{array}{l}\text { L-asparaginase } \\
\text { (international units) }\end{array}$ & $\begin{array}{l}\text { Multiplier } \\
\text { model } \\
\% \text { diff }\end{array}$ & $\begin{array}{c}175,327,626 \\
179,690,006 \\
2 \%\end{array}$ & $\begin{array}{c}18,802,243 \\
17,087,143 \\
-9 \%\end{array}$ & $\begin{array}{c}38,486,189 \\
34,926,460 \\
-9 \%\end{array}$ & $\begin{array}{c}2,063,586 \\
2,182,004 \\
6 \%\end{array}$ \\
\hline $\begin{array}{l}\text { Intrathecal } \\
\text { methotrexate } \\
\text { milligrams }\end{array}$ & $\begin{array}{l}\text { Multiplier } \\
\text { model } \\
\% \text { diff }\end{array}$ & $\begin{array}{c}585,427 \\
584,900 \\
0 \%\end{array}$ & $\begin{array}{c}62,782 \\
62,725 \\
0 \%\end{array}$ & $\begin{array}{c}128,507 \\
128,392 \\
0 \%\end{array}$ & $\begin{array}{c}6,890 \\
6,884 \\
0 \%\end{array}$ \\
\hline $\begin{array}{l}\text { Methotrexate oral } \\
\text { milligrams }\end{array}$ & $\begin{array}{l}\text { Multiplier } \\
\text { model } \\
\% \text { diff }\end{array}$ & $\begin{array}{c}3,413,893 \\
3,497,965 \\
2 \%\end{array}$ & $\begin{array}{c}366,108 \\
332,630 \\
-9 \%\end{array}$ & $\begin{array}{c}749,384 \\
679,902 \\
-9 \%\end{array}$ & $\begin{array}{c}40,181 \\
42,476 \\
6 \%\end{array}$ \\
\hline $\begin{array}{l}\text { Methotrexate IV } \\
\text { milligrams }\end{array}$ & $\begin{array}{l}\text { Multiplier } \\
\text { model } \\
\% \text { diff }\end{array}$ & $\begin{array}{c}195,142 \\
199,656 \\
2 \%\end{array}$ & $\begin{array}{c}20,927 \\
18,986 \\
-9 \%\end{array}$ & $\begin{array}{c}42,836 \\
38,807 \\
-9 \%\end{array}$ & $\begin{array}{c}2,297 \\
2,424 \\
6 \%\end{array}$ \\
\hline
\end{tabular}


Table 4-4. (Continued)

\begin{tabular}{|c|c|c|c|c|c|}
\hline Medication dosage & $\begin{array}{c}\text { Reason } \\
\text { for } \\
\text { selection } \\
\end{array}$ & $\begin{array}{c}\text { Brazil } \\
\text { 1 standard } \\
\text { deviation more } \\
\text { than the mean } \\
\text { weighted BSA }\end{array}$ & $\begin{array}{c}\text { Kazakhstan } \\
2 \text { standard } \\
\text { deviations less } \\
\text { than the mean } \\
\text { weighted BSA }\end{array}$ & $\begin{array}{c}\text { Niger } \\
\text { Greatest } \\
\text { percentage of } \\
\text { children aged } \\
0-4 \text { years }\end{array}$ & $\begin{array}{c}\text { Albania } \\
\text { Greatest } \\
\text { percentage of } \\
\text { children aged } \\
15-19 \text { years }\end{array}$ \\
\hline $\begin{array}{l}\text { Dexamethasone } \\
\text { milligrams }\end{array}$ & $\begin{array}{l}\text { Multiplier } \\
\text { model } \\
\% \text { diff }\end{array}$ & $\begin{array}{c}1,780,399 \\
1,824,852 \\
2 \%\end{array}$ & $\begin{array}{c}190,931 \\
173,529 \\
-9 \%\end{array}$ & $\begin{array}{c}390,816 \\
354,698 \\
-9 \%\end{array}$ & $\begin{array}{c}20,955 \\
22,159 \\
6 \%\end{array}$ \\
\hline $\begin{array}{l}\text { Mercaptopurine } \\
\text { milligrams }\end{array}$ & $\begin{array}{l}\text { Multiplier } \\
\text { model } \\
\% \text { diff }\end{array}$ & $\begin{array}{c}24,690,975 \\
25,306,343 \\
2 \%\end{array}$ & $\begin{array}{c}2,647,875 \\
2,406,439 \\
-9 \%\end{array}$ & $\begin{array}{c}5,419,919 \\
4,918,810 \\
-9 \%\end{array}$ & $\begin{array}{c}290,610 \\
307,299 \\
6 \%\end{array}$ \\
\hline $\begin{array}{l}\text { Doxorubicin } \\
\text { milligrams }\end{array}$ & $\begin{array}{l}\text { Multiplier } \\
\text { model } \\
\% \text { diff }\end{array}$ & $\begin{array}{c}146,905 \\
149,742 \\
2 \%\end{array}$ & $\begin{array}{c}15,754 \\
14,239 \\
-10 \%\end{array}$ & $\begin{array}{c}32,247 \\
29,105 \\
-10 \%\end{array}$ & $\begin{array}{c}1,729 \\
1,818 \\
5 \%\end{array}$ \\
\hline $\begin{array}{l}\text { Cyclophosphamide } \\
\text { milligrams }\end{array}$ & $\begin{array}{l}\text { Multiplier } \\
\text { model } \\
\% \text { diff }\end{array}$ & $\begin{array}{c}4,402,760 \\
4,512,216 \\
2 \%\end{array}$ & $\begin{array}{c}472,155 \\
429,077 \\
-9 \%\end{array}$ & $\begin{array}{c}966,450 \\
877,042 \\
-9 \%\end{array}$ & $\begin{array}{c}51,820 \\
54,793 \\
6 \%\end{array}$ \\
\hline $\begin{array}{l}\text { Cytarabine } \\
\text { milligrams }\end{array}$ & $\begin{array}{c}\text { Multiplier } \\
\text { model } \\
\% \text { diff } \\
\end{array}$ & $\begin{array}{c}2,642,094 \\
2,707,329 \\
2 \% \\
\end{array}$ & $\begin{array}{c}283,340 \\
257,446 \\
-9 \% \\
\end{array}$ & $\begin{array}{c}579,966 \\
526,225 \\
-9 \% \\
\end{array}$ & $\begin{array}{c}31,097 \\
32,876 \\
6 \% \\
\end{array}$ \\
\hline
\end{tabular}

Notes: BSA - Body surface area. Weighted BSA, based upon age distribution. Multiplier, Nations' estimated incidence of acute lymphoblastic leukemia was multiplied by the individual patient multiplier. Model, each nation's drug requirement was estimated via the full predictive model. Intrathecal methotrexate, doses were rounded to $12 \mathrm{mg}$ 
Table 4-5. Patient and population multipliers for International Society of Paediatric Oncology Adapted Acute Lymphoblastic Leukemia Regimen Level 1 without cranial radiation

\begin{tabular}{|c|c|c|c|c|c|c|c|}
\hline Medication & Multiplier & $\begin{array}{c}\text { LIC } \\
\text { minimum } \\
\end{array}$ & $\begin{array}{c}\text { LIC } \\
\text { maximum }\end{array}$ & $\begin{array}{c}\text { LIC } \\
\text { minimum }\end{array}$ & $\begin{array}{c}\text { LIC } \\
\text { maximum }\end{array}$ & $\begin{array}{c}\text { LIC } \\
\text { minimum } \\
\end{array}$ & $\begin{array}{c}\text { LIC } \\
\text { maximum } \\
\end{array}$ \\
\hline \multirow{2}{*}{$\begin{array}{l}\text { Prednisone } \\
\text { milligrams }\end{array}$} & Patient & 300 & 1,155 & 393 & 1,155 & 716 & 1,155 \\
\hline & Population & 0.0106 & 0.0409 & 0.0139 & 0.0409 & 0.0254 & 0.0409 \\
\hline \multirow{2}{*}{$\begin{array}{l}\text { Vincristine } \\
\text { milligrams }\end{array}$} & Patient & 12 & 48 & 16 & 48 & 30 & 48 \\
\hline & Population & 0.0004 & 0.0016 & 0.00054 & 0.0016 & 0.0010 & 0.0016 \\
\hline \multirow{2}{*}{$\begin{array}{l}\text { L-asparaginase } \\
\text { international units }\end{array}$} & Patient & 12,474 & 47,978 & 16,313 & 47,978 & 29,746 & 47,978 \\
\hline & Population & 0.4416 & 1.6984 & 0.5775 & 1.6984 & 1.0530 & 1.6984 \\
\hline \multirow{2}{*}{$\begin{array}{l}\text { Methotrexate IT } \\
\text { milligrams }\end{array}$} & Patient & 62 & 240 & 82 & 240 & 149 & 240 \\
\hline & Population & 0.0022 & 0.0085 & 0.0029 & 0.0085 & 0.0053 & 0.0085 \\
\hline \multirow{2}{*}{$\begin{array}{l}\text { Methotrexate oral } \\
\text { milligrams }\end{array}$} & Patient & 490 & 1,884 & 641 & 1,884 & 1,168 & 1,884 \\
\hline & Population & 0.0173 & 0.0667 & 0.0227 & 0.0667 & 0.0414 & 0.0667 \\
\hline $\begin{array}{l}\text { Methotrexate IV } \\
\text { milligrams }\end{array}$ & $\begin{array}{c}\text { Patient } \\
\text { Population }\end{array}$ & & & & & & \\
\hline \multirow{2}{*}{$\begin{array}{l}\text { Dexamethasone } \\
\text { milligrams }\end{array}$} & Patient & 208 & 800 & 272 & 800 & 496 & 800 \\
\hline & Population & 0.0074 & 0.0283 & 0.0096 & 0.0283 & 0.0175 & 0.0283 \\
\hline \multirow{2}{*}{$\begin{array}{l}\text { Mercaptopurine } \\
\text { milligrams }\end{array}$} & Patient & 15,038 & 57,840 & 19,666 & 57,840 & 35,861 & 57,840 \\
\hline & Population & 0.5324 & 2.0475 & 0.6962 & 2.0475 & 1.2695 & 2.0475 \\
\hline $\begin{array}{l}\text { Doxorubicin } \\
\text { milligrams }\end{array}$ & $\begin{array}{c}\text { Patient } \\
\text { Population }\end{array}$ & & & & & & \\
\hline
\end{tabular}


Table 4-5. (Continued)

\begin{tabular}{|c|c|c|c|c|c|c|c|}
\hline Medication & Multiplier & $\begin{array}{c}\text { LIC } \\
\text { minimum }\end{array}$ & $\begin{array}{c}\text { LIC } \\
\text { maximum }\end{array}$ & $\begin{array}{c}\text { LIC } \\
\text { minimum }\end{array}$ & $\begin{array}{c}\text { LIC } \\
\text { maximum }\end{array}$ & $\begin{array}{c}\text { LIC } \\
\text { minimum }\end{array}$ & $\begin{array}{c}\text { LIC } \\
\text { maximum }\end{array}$ \\
\hline $\begin{array}{l}\text { Cyclophosphamide } \\
\text { milligrams }\end{array}$ & $\begin{array}{c}\text { Patient } \\
\text { Population }\end{array}$ & & & & & & \\
\hline $\begin{array}{l}\text { Cytarabine } \\
\text { milligrams }\end{array}$ & $\begin{array}{c}\text { Patient } \\
\text { Population }\end{array}$ & & & & & & \\
\hline
\end{tabular}

Notes: LIC - Low-income-country; LMIC - Low-middle-income-country; UMIC - Upper middle-income-country; IT - Intrathecal; IV - Intravenous. Patient, Individual patient multiplier. Population, Population multiplier. 
Table 4-6. Patient and population multipliers for International Society of Paediatric Oncology Adapted Acute Lymphoblastic Leukemia Regimen Level 1 with cranial radiation

\begin{tabular}{|c|c|c|c|c|c|c|c|}
\hline Medication & Multiplier & $\begin{array}{c}\text { LIC } \\
\text { minimum }\end{array}$ & $\begin{array}{c}\text { LIC } \\
\text { maximum }\end{array}$ & $\begin{array}{c}\text { LIC } \\
\text { minimum }\end{array}$ & $\begin{array}{c}\text { LIC } \\
\text { maximum }\end{array}$ & $\begin{array}{c}\text { LIC } \\
\text { minimum }\end{array}$ & $\begin{array}{c}\text { LIC } \\
\text { maximum }\end{array}$ \\
\hline \multirow{2}{*}{$\begin{array}{l}\text { Prednisone } \\
\text { milligrams }\end{array}$} & Patient & 300 & 1,155 & 393 & 1,155 & 716 & 1,155 \\
\hline & Population & 0.0106 & 0.0409 & 0.0139 & 0.0409 & 0.0254 & 0.0409 \\
\hline \multirow{2}{*}{$\begin{array}{l}\text { Vincristine } \\
\text { milligrams }\end{array}$} & Patient & 12 & 48 & 16 & 48 & 30 & 48 \\
\hline & Population & 0.0004 & 0.0016 & 0.00054 & 0.0016 & 0.0010 & 0.0016 \\
\hline \multirow{2}{*}{$\begin{array}{l}\text { L-asparaginase } \\
\text { international units }\end{array}$} & Patient & 12,474 & 47,978 & 16,313 & 47,978 & 29,746 & 47,978 \\
\hline & Population & 0.4416 & 1.6984 & 0.5775 & 1.6984 & 1.0530 & 1.6984 \\
\hline \multirow{2}{*}{$\begin{array}{l}\text { Methotrexate IT } \\
\text { milligrams }\end{array}$} & Patient & 55 & 210 & 71 & 210 & 130 & 210 \\
\hline & Population & 0.0019 & 0.0074 & 0.0025 & 0.0074 & 0.0046 & 0.0074 \\
\hline \multirow{2}{*}{$\begin{array}{l}\text { Methotrexate Oral } \\
\text { milligrams }\end{array}$} & Patient & 501 & 1,928 & 656 & 1,928 & 1,195 & 1,928 \\
\hline & Population & 0.0178 & 0.0683 & 0.0232 & 0.0683 & 0.0423 & 0.0683 \\
\hline $\begin{array}{l}\text { Methotrexate IV } \\
\text { milligrams }\end{array}$ & $\begin{array}{l}\text { Patient } \\
\text { Population }\end{array}$ & & & & & & \\
\hline \multirow{2}{*}{$\begin{array}{l}\text { Dexamethasone } \\
\text { milligrams }\end{array}$} & Patient & 208 & 800 & 272 & 800 & 496 & 800 \\
\hline & Population & 0.0074 & 0.0283 & 0.0175 & 0.0283 & 0.0175 & 0.0283 \\
\hline \multirow{2}{*}{$\begin{array}{l}\text { Mercaptopurine } \\
\text { milligrams }\end{array}$} & Patient & 15,038 & 57,840 & 19,666 & 57,840 & 35,861 & 57,840 \\
\hline & Population & 0.5324 & 2.0475 & 0.6962 & 2.0475 & 1.2695 & 2.0475 \\
\hline $\begin{array}{l}\text { Doxorubicin } \\
\text { milligrams }\end{array}$ & $\begin{array}{c}\text { Patient } \\
\text { Population }\end{array}$ & & & & & & \\
\hline
\end{tabular}


Table 4-6. (Continued)

\begin{tabular}{|c|c|c|c|c|c|c|c|}
\hline Medication & Multiplier & $\begin{array}{c}\text { LIC } \\
\text { minimum } \\
\end{array}$ & $\begin{array}{c}\text { LIC } \\
\text { maximum } \\
\end{array}$ & $\begin{array}{c}\text { LIC } \\
\text { minimum } \\
\end{array}$ & $\begin{array}{c}\text { LIC } \\
\text { maximum } \\
\end{array}$ & $\begin{array}{c}\text { LIC } \\
\text { minimum } \\
\end{array}$ & $\begin{array}{c}\text { LIC } \\
\text { maximum } \\
\end{array}$ \\
\hline $\begin{array}{l}\text { Cyclophosphamide } \\
\text { milligrams }\end{array}$ & $\begin{array}{c}\text { Patient } \\
\text { Population }\end{array}$ & & & & & & \\
\hline $\begin{array}{l}\text { Cytarabine } \\
\text { milligrams }\end{array}$ & $\begin{array}{c}\text { Patient } \\
\text { Population }\end{array}$ & & & & & & \\
\hline
\end{tabular}

Notes: LIC - Low-income-country; LMIC - Low-middle-income-country; UMIC - Upper middle-income-country; IT - Intrathecal; IV - Intravenous. Patient, Individual patient multiplier; Population, Population multiplier 
Table 4-7. Patient and population multipliers for International Society of Paediatric Oncology Adapted Acute Lymphoblastic Leukemia Regimen Level 2 with cranial radiation

\begin{tabular}{|c|c|c|c|c|c|c|c|}
\hline Medication & Multiplier & $\begin{array}{c}\text { LIC } \\
\text { minimum }\end{array}$ & $\begin{array}{c}\text { LIC } \\
\text { maximum }\end{array}$ & $\begin{array}{c}\text { LIC } \\
\text { minimum }\end{array}$ & $\begin{array}{c}\text { LIC } \\
\text { maximum }\end{array}$ & $\begin{array}{c}\text { LIC } \\
\text { minimum }\end{array}$ & $\begin{array}{c}\text { LIC } \\
\text { maximum }\end{array}$ \\
\hline \multirow{2}{*}{$\begin{array}{l}\text { Prednisone } \\
\text { milligrams }\end{array}$} & Patient & 364 & 1,401 & 476 & 1,401 & 869 & 1,401 \\
\hline & Population & 0.0129 & 0.0496 & 0.0169 & 0.0496 & 0.0308 & 0.0496 \\
\hline \multirow{2}{*}{$\begin{array}{l}\text { Vincristine } \\
\text { milligrams }\end{array}$} & Patient & 12 & 48 & 16 & 48 & 30 & 48 \\
\hline & Population & 0.0004 & 0.0016 & 0.00054 & 0.0016 & 0.0010 & 0.0016 \\
\hline \multirow{2}{*}{$\begin{array}{l}\text { L-asparaginase } \\
\text { international units }\end{array}$} & Patient & 17,713 & 68,128 & 23,164 & 68,128 & 42,239 & 68,128 \\
\hline & Population & 0.6270 & 2.4117 & 0.8200 & 2.4117 & 1.4953 & 2.4117 \\
\hline \multirow{2}{*}{$\begin{array}{l}\text { Methotrexate IT } \\
\text { milligrams }\end{array}$} & Patient & 65 & 250 & 85 & 250 & 155 & 250 \\
\hline & Population & 0.0023 & 0.0089 & 0.0030 & 0.0089 & 0.0055 & 0.0089 \\
\hline \multirow{2}{*}{$\begin{array}{l}\text { Methotrexate Oral } \\
\text { milligrams }\end{array}$} & Patient & 451 & 1,734 & 590 & 1,734 & 1,075 & 1,734 \\
\hline & Population & 0.0160 & 0.0614 & 0.0209 & 0.0614 & 0.0381 & 0.0614 \\
\hline \multirow{2}{*}{$\begin{array}{l}\text { Methotrexate IV } \\
\text { milligrams }\end{array}$} & Patient & & & & & & \\
\hline & Population & & & & & & \\
\hline \multirow{2}{*}{$\begin{array}{l}\text { Dexamethasone } \\
\text { milligrams }\end{array}$} & Patient & 211 & 811 & 276 & 811 & 503 & 811 \\
\hline & Population & 0.0075 & 0.0287 & 0.0178 & 0.0287 & 0.0178 & 0.0287 \\
\hline \multirow{2}{*}{$\begin{array}{l}\text { Mercaptopurine } \\
\text { milligrams }\end{array}$} & Patient & 7,463 & 28,705 & 9,760 & 28,705 & 17,797 & 28,705 \\
\hline & Population & 0.2642 & 1.0162 & 0.3455 & 1.0162 & 0.6300 & 1.0162 \\
\hline \multirow{2}{*}{$\begin{array}{l}\text { Doxorubicin } \\
\text { milligrams }\end{array}$} & Patient & 11 & 42 & 14 & 42 & 26 & 42 \\
\hline & Population & 0.0004 & 0.0015 & 0.0005 & 0.0015 & 0.0009 & 0.0015 \\
\hline
\end{tabular}


Table 4-7. (Continued)

\begin{tabular}{lccccccc}
\hline Medication & Multiplier & $\begin{array}{c}\text { LIC } \\
\text { minimum }\end{array}$ & $\begin{array}{c}\text { LIC } \\
\text { maximum }\end{array}$ & $\begin{array}{c}\text { LIC } \\
\text { minimum }\end{array}$ & $\begin{array}{c}\text { LIC } \\
\text { maximum }\end{array}$ & $\begin{array}{c}\text { LIC } \\
\text { minimum }\end{array}$ & $\begin{array}{c}\text { LIC } \\
\text { maximum }\end{array}$ \\
\hline $\begin{array}{l}\text { Cyclophosphamide } \\
\text { milligrams }\end{array}$ & $\begin{array}{c}\text { Patient } \\
\text { Population }\end{array}$ & 0.0051 & 0.0198 & 0.0067 & 0.0198 & 0.0123 & 0.0198 \\
& & & & & & & \\
Cytarabine & Patient & 87 & 336 & 114 & 336 & 208 & 336 \\
milligrams & Population & 0.0031 & 0.0119 & 0.0040 & 0.0119 & 0.0074 & 0.0119 \\
\hline
\end{tabular}

Notes: LIC - Low-income-country; LMIC - Low-middle-income-country; UMIC - Upper middle-income-country; IT - Intrathecal; IV - Intravenous. Patient, Individual patient multiplier. Population, Population multiplier. 
Table 4-8. Patient and population multipliers for International Society of Paediatric Oncology Adapted Acute Lymphoblastic Leukemia Regimen Level 3

\begin{tabular}{|c|c|c|c|c|c|c|c|}
\hline Medication & Multiplier & $\begin{array}{c}\text { LIC } \\
\text { minimum }\end{array}$ & $\begin{array}{c}\text { LIC } \\
\text { maximum }\end{array}$ & $\begin{array}{c}\text { LIC } \\
\text { minimum }\end{array}$ & $\begin{array}{c}\text { LIC } \\
\text { maximum }\end{array}$ & $\begin{array}{c}\text { LIC } \\
\text { minimum }\end{array}$ & $\begin{array}{c}\text { LIC } \\
\text { maximum }\end{array}$ \\
\hline \multirow{2}{*}{$\begin{array}{l}\text { Prednisone } \\
\text { milligrams }\end{array}$} & Patient & 402 & 1,546 & 526 & 1,546 & 959 & 1,546 \\
\hline & Population & 0.0142 & 0.0547 & 0.0186 & 0.0547 & 0.0339 & 0.0547 \\
\hline \multirow{2}{*}{$\begin{array}{l}\text { Vincristine } \\
\text { milligrams }\end{array}$} & Patient & 12 & 45 & 15 & 45 & 28 & 45 \\
\hline & Population & 0.0004 & 0.0016 & 0.0005 & 0.0016 & 0.0010 & 0.0016 \\
\hline \multirow{2}{*}{$\begin{array}{l}\text { L-asparaginase } \\
\text { international units }\end{array}$} & Patient & 20,790 & 79,963 & 27,187 & 79,963 & 49,577 & 79,963 \\
\hline & Population & 0.7360 & 2.8307 & 0.9624 & 2.8307 & 1.7550 & 2.8307 \\
\hline \multirow{2}{*}{$\begin{array}{l}\text { Methotrexate IT } \\
\text { milligrams }\end{array}$} & Patient & 69 & 267 & 91 & 267 & 166 & 267 \\
\hline & Population & 0.0024 & 0.0094 & 0.0032 & 0.0094 & 0.0058 & 0.0094 \\
\hline \multirow{2}{*}{$\begin{array}{l}\text { Methotrexate Oral } \\
\text { milligrams }\end{array}$} & Patient & 405 & 1,557 & 529 & 1,557 & 965 & 1,557 \\
\hline & Population & 0.0143 & 0.0551 & 0.0187 & 0.0551 & 0.0342 & 0.0551 \\
\hline \multirow{2}{*}{$\begin{array}{l}\text { Methotrexate IV } \\
\text { milligrams }\end{array}$} & Patient & 23 & 89 & 30 & 89 & 55 & 89 \\
\hline & Population & 0.0008 & 0.0031 & 0.0011 & 0.0031 & 0.0019 & 0.0031 \\
\hline \multirow{2}{*}{$\begin{array}{l}\text { Dexamethasone } \\
\text { milligrams }\end{array}$} & Patient & 211 & 812 & 276 & 812 & 503 & 812 \\
\hline & Population & 0.0075 & 0.0287 & 0.0098 & 0.0287 & 0.0178 & 0.0287 \\
\hline \multirow{2}{*}{$\begin{array}{l}\text { Mercaptopurine } \\
\text { milligrams }\end{array}$} & Patient & 2,928 & 11,261 & 3,829 & 11,261 & 6,982 & 11,261 \\
\hline & Population & 0.1037 & 0.3987 & 0.1356 & 0.3987 & 0.2472 & 0.3987 \\
\hline \multirow{2}{*}{$\begin{array}{l}\text { Doxorubicin } \\
\text { milligrams }\end{array}$} & Patient & 17 & 67 & 23 & 67 & 42 & 67 \\
\hline & Population & 0.0006 & 0.0024 & 0.0008 & 0.0024 & 0.0015 & 0.0024 \\
\hline
\end{tabular}


Table 4-8. (Continued)

\begin{tabular}{|c|c|c|c|c|c|c|c|}
\hline Medication & Multiplier & $\begin{array}{c}\text { LIC } \\
\text { minimum }\end{array}$ & $\begin{array}{c}\text { LIC } \\
\text { maximum }\end{array}$ & $\begin{array}{c}\text { LIC } \\
\text { minimum }\end{array}$ & $\begin{array}{c}\text { LIC } \\
\text { maximum }\end{array}$ & $\begin{array}{c}\text { LIC } \\
\text { minimum }\end{array}$ & $\begin{array}{c}\text { LIC } \\
\text { maximum }\end{array}$ \\
\hline \multirow{2}{*}{$\begin{array}{l}\text { Cyclophosphamide } \\
\text { milligrams }\end{array}$} & Patient & 522 & 2008 & 683 & 2008 & 1,245 & 2008 \\
\hline & Population & 0.0185 & 0.0711 & 0.0242 & 0.0711 & 0.0441 & 0.0711 \\
\hline Cytarabine & Patient & 313 & 1205 & 410 & 1205 & 747 & 1205 \\
\hline milligrams & Population & 0.0111 & 0.0426 & 0.0145 & 0.0426 & 0.0264 & 0.0426 \\
\hline
\end{tabular}

Notes: LIC - Low-income-country; LMIC - Low-middle-income-country; UMIC - Upper middle-income-country; IT - Intrathecal; IV - Intravenous. Patient, Individual patient multiplier. Population, Population multiplier. 
Table 4-9. Shelf life and storage requirements for medications used to treat acute lymphoblastic leukemia with the International Society of Paediatric Oncology Regimens

\begin{tabular}{|c|c|c|c|c|c|c|}
\hline Medication & Form & Route & Shelf life & $\begin{array}{c}\text { Special } \\
\text { instructions }\end{array}$ & $\begin{array}{c}\text { Storage } \\
\text { requirements }\end{array}$ & $\begin{array}{c}\text { Temperature range } \\
\text { (degrees Celsius) }\end{array}$ \\
\hline Prednisone & Tablets & Oral & $\begin{array}{c}36 \\
\text { Months }\end{array}$ & $\begin{array}{l}\text { Protect from } \\
\text { light and } \\
\text { moisture }\end{array}$ & $\begin{array}{c}\text { Room } \\
\text { temperature }\end{array}$ & 15 to 25 \\
\hline Vincristine & Solution & IV & $\begin{array}{c}24 \\
\text { Months }\end{array}$ & $\begin{array}{l}\text { Protect from } \\
\text { light }\end{array}$ & Cold chain & 2 to 8 \\
\hline L-asparaginase & $\begin{array}{l}\text { Solution or } \\
\text { powder }\end{array}$ & $\begin{array}{l}\text { IV or } \\
\text { IM }\end{array}$ & $\begin{array}{c}36 \\
\text { Months }\end{array}$ & $\begin{array}{c}\text { Neutral glass } \\
\text { vial }\end{array}$ & Cold chain & 2 to 8 \\
\hline $\begin{array}{l}\text { PEG-asparaginase } \\
\text { (Oncaspar) }\end{array}$ & Solution & $\begin{array}{l}\text { IV or } \\
\text { IM }\end{array}$ & 8 Months & $\begin{array}{l}\text { Do not shake or } \\
\text { freeze, protect } \\
\text { from light }\end{array}$ & Cold chain & 2 to 8 \\
\hline $\begin{array}{l}\text { PEG-asparaginase } \\
\text { (Oncaspar) }\end{array}$ & Powder & $\begin{array}{l}\text { IV or } \\
\text { IM }\end{array}$ & 3 Years & Do not freeze & Cold chain & 2 to 8 \\
\hline Methotrexate & Tablets & Oral & $\begin{array}{l}36 \text { or } 60 \\
\text { Months }\end{array}$ & None & $\begin{array}{c}\text { Room } \\
\text { temperature }\end{array}$ & 20 to 25 \\
\hline Methotrexate & Solution & $\begin{array}{l}\text { IV or } \\
\text { IM }\end{array}$ & $\begin{array}{c}24 \\
\text { Months }\end{array}$ & $\begin{array}{c}\text { Protect from } \\
\text { light }\end{array}$ & $\begin{array}{c}\text { Room } \\
\text { temperature }\end{array}$ & 15 to 25 \\
\hline Methotrexate & Oral solution & Oral & $\begin{array}{c}18 \\
\text { Months }\end{array}$ & $\begin{array}{l}\text { Protect from } \\
\text { light }\end{array}$ & Cold chain & 2 to 8 \\
\hline Dexamethasone & Tablets & Oral & $\begin{array}{c}36 \\
\text { Months }\end{array}$ & $\begin{array}{l}\text { Protect from } \\
\text { light }\end{array}$ & $\begin{array}{c}\text { Room } \\
\text { temperature }\end{array}$ & 20 to 25 \\
\hline
\end{tabular}


Table 4-9. (Continued)

\begin{tabular}{|c|c|c|c|c|c|c|}
\hline Medication & Form & Route & $\begin{array}{l}\text { Shelf } \\
\text { Life }\end{array}$ & $\begin{array}{c}\text { Special } \\
\text { instructions }\end{array}$ & $\begin{array}{c}\text { Storage } \\
\text { requirements }\end{array}$ & $\begin{array}{l}\text { Temperature Range } \\
\text { (degrees Celsius) }\end{array}$ \\
\hline Dexamethasone & Solution & IV & $\begin{array}{c}21 \\
\text { Months }\end{array}$ & $\begin{array}{c}\text { Protect from } \\
\text { light }\end{array}$ & $\begin{array}{c}\text { Room } \\
\text { temperature }\end{array}$ & 20 to 25 \\
\hline Mercaptopurine & Tablets & Oral & $\begin{array}{c}60 \\
\text { Months }\end{array}$ & $\begin{array}{l}\text { Protect from } \\
\text { moisture }\end{array}$ & $\begin{array}{l}\text { Room } \\
\text { temperature }\end{array}$ & 15 to 25 \\
\hline Mercaptopurine & $\begin{array}{c}\text { Oral } \\
\text { suspension }\end{array}$ & Oral & $\begin{array}{c}15 \\
\text { Months }\end{array}$ & $\begin{array}{l}\text { Protect from } \\
\text { moisture }\end{array}$ & $\begin{array}{l}\text { Room } \\
\text { temperature }\end{array}$ & 15 to 25 \\
\hline Doxorubicin & Solution & IV & $\begin{array}{c}24 \\
\text { Months }\end{array}$ & Refrigerate & Cold chain & 2 to 8 \\
\hline Cyclophosphamide & Tablets & Oral & $\begin{array}{c}36 \\
\text { Months }\end{array}$ & $\begin{array}{l}\text { Protect from } \\
\text { temperatures } \\
\text { above } 25 \mathrm{C}\end{array}$ & $\begin{array}{l}\text { Room } \\
\text { temperature }\end{array}$ & 15 to 25 \\
\hline Cyclophosphamide & $\begin{array}{l}\text { Solution or } \\
\text { powder }\end{array}$ & IV & $\begin{array}{c}24 \\
\text { Months }\end{array}$ & $\begin{array}{l}\text { Protect from } \\
\text { temperatures } \\
\text { above } 25 \mathrm{C}\end{array}$ & $\begin{array}{l}\text { Room } \\
\text { temperature }\end{array}$ & 15 to 25 \\
\hline Cytarabine & $\begin{array}{l}\text { Solution for } \\
\text { infusion or } \\
\text { injection }\end{array}$ & IV & $\begin{array}{c}18 \\
\text { Months }\end{array}$ & $\begin{array}{l}\text { Should not be } \\
\text { refrigerated }\end{array}$ & $\begin{array}{c}\text { Room } \\
\text { temperature }\end{array}$ & 20 to 25 \\
\hline
\end{tabular}

Note: Data adapted from U.S. Food \& Drug Administration. (2018). Drugs@FDA: FDA-Approved Drugs. Retrieved from https://www.accessdata.fda.gov/scripts/cder/daf/ and Electronic Medicines Compendium. (n.d.). Latest Medicine Updates. Retrieved from https://www.medicines.org.uk/emc/. 


\section{Discussion}

This study described multipliers derived from a forecasting model that utilizes publicly available data to estimate the quantity of essential chemotherapy needed for a child diagnosed with ALL. The goal of the UN World Populations Prospects is to provide accurate and timely population data for all countries (United Nations, 2019). WHO and CDC growth charts can be used for any country-specific initial forecasts, and country-specific ALL incidence rates do not differ dramatically from SEER incidence rates (Allemani et al.; Centers for Disease Control and Prevention, 2010; Katz et al., 2015). The SIOP Adapted ALL Regimens are appropriate for all countries (Hunger et al., 2009). Understanding essential chemotherapy requirements for each regimen allows appropriate modifications of practice during times of shortages.

\section{Implications for Practice}

If a country's childhood population is evenly distributed across the 4 age cohorts $(25 \% 0$ 4 years, 25\% 5-9 years, 25\% 10-14 years, and 25\% 15-19 years), then the country's weighted body surface area average will be 1.09 . In such a case, there would not be a difference between the estimated essential chemotherapy of the forecasting model for that country and the patient and population multipliers. The multipliers did not show variations greater than $15 \%$ from the forecasting model, making multipliers valuable to healthcare providers and policy makers. Healthcare providers can use the multipliers to quickly establish and adjust their daily, weekly, or monthly need of essential chemotherapy for their treatment center. Then based upon the storage capacity of their facility, they can determine the amount of essential chemotherapy to maintain in inventory and the amount and frequency at which to order essential chemotherapy.

Policy makers could ensure their country has a national Essential Medicines List (EML) that is updated every 2 years and contains all essential chemotherapy listed according to the WHO and SIOP list of essential medications. This is recognized as an important step for procurement and availability of essential chemotherapy for LMIC (Barr \& Robertson, 2016). It is important for policy makers to understand that maintaining appropriate inventory levels, regular buying patterns, and ensuring storage requirements have increased children's access to essential chemotherapy and reduced acquisition cost (Denburg et al., 2014; Moye-Holz et al., 2017). With this understanding, supply chain procedures can be put in place to ensure that a supply of the minimum estimate of the 9 essential chemotherapies to treat ALL is maintained in-country by monthly ordering patterns from multiple sources. The minimum multipliers could be utilized to establish the initial inventory levels.

\section{Limitations}

The multipliers were based on surrogate measures of ALL incidence and growth curves to calculate doses by age and imputed percentages of each ALL risk group, which may introduce error in estimated chemotherapy needs. Furthermore, the UN World Populations Prospects is based upon population estimates and projections rather than the actual population which introduces an additional degree of error (United Nations, 2019). Patient-level data addressed all 
of these weaknesses since they directly measured incidence, relied on measurement of patients' actual height and weight rather than estimates from population curves, and considered the treatment regimen used. However, these are not always available in LMIC where forecasting models could provide the greatest assistance. Publicly available databases used in this study did, however, provide sound forecasts for countries, regions, and centers currently having little basis upon which to stock essential chemotherapies. Also, information systems are available at no cost (e.g., www.ResonanceOncology.org) to facilitate such direct measurements and automatically calculate a patient's forecasted need prospectively and actual chemotherapy received by documenting each dose in the system-generated, individualized chemotherapy roadmap.

Non-specific country standard growth charts were used in calculating chemotherapy forecasting and may have introduced error in the estimated need. The WHO and CDC growth curves are standardized and widely utilized. However, values for children in each country inevitably differ and can even vary by region or ethnic group within the same country. In addition to these expected variations, we suspect that the WHO and CDC growth curves for children in LMIC, in particular, may overestimate chemotherapy needs (de Onis et al., 2010; Poskitt, 2014). For example, the WHO reported higher obesity among children in the US and more growth-stunting in LMIC, which could lead to underestimation of chemotherapy needed for children in the US and overestimation for those in LMIC (World Health Organization, 2018).

Where age-specific obesity rates are known, the model could be refined, or ideally, individual patient data could be used to create accurate forecasts by patient, center, region, and country. The minimum estimates of essential chemotherapies were based upon non-diagnosis, incorrect or delayed diagnosis, unaffordability, abandonment and refusal of treatment, and relapse based upon countries' World Bank categorizations (Lam et al., 2019). Individual countries may have non-diagnosis, incorrect or delayed diagnosis, unaffordability, abandonment and refusal of treatment, and relapse rates that are less than or greater than what is typical of their World Bank categorization.

\section{Future Directions}

The established multipliers for the SIOP Adapted ALL Regimens would benefit from being examined in three ways. First, one could investigate if minimum multipliers are useful in determining in-country inventory levels and buying patterns. Second, one could also analyze if maximum multipliers are useful in estimating the 9 essential chemotherapies for individual children who complete the SIOP Adapted ALL Regimens. Last, one could example how multipliers compare to actual patient-level data utilized in information systems.

\section{Conclusion}

We found that patient and population multipliers are feasible, which allows stakeholders including providers, cancer centers, hospitals, countries, and drug manufacturers to quickly estimate essential chemotherapies for a patient or population and strategically manage their 
inventory and purchasing to treat ALL. This model is practical and can be applied to other cancer types and treatment protocols. 


\section{CHAPTER 5. CONCLUSION}

\section{Summary of Findings}

Lack of access to essential chemotherapy is a significant disparity for children and adolescents diagnosed with cancer in in low- and middle-income countries (LMIC) (Denburg et al., 2014; Lam et al., 2019; Moye-Holz et al., 2017; Simonyan et al., 2019). A key contributor to this disparity is the lack of accurate forecasting for the needed essential chemotherapy. My work has demonstrated that disease incidence can be utilized to forecast the needed essential chemotherapeutic agents to treat acute lymphoblastic leukemia (ALL) for a patient, center, region, and country; in the same manner, and population and patient multipliers are feasible using existing public data sources.

\section{Strengths of Study}

The National Institutes of Health (NIH), National Cancer Institute (NCI), and Surveillance, Epidemiology, and End Results (SEER) Cancer Statistics Review (CSR) 19752010 data provided incidence rates of ALL for each year of childhood for the ages of 0 to 19 (Lam et al., 2019). Country-specific ALL incidence rates did not differ dramatically from SEER rates, especially after accounting for non-diagnosis (Katz et al., 2015; Lam et al., 2019). The International Society of Paediatric Oncology (SIOP) Adapted ALL Regimens included treatment strata appropriate for all countries (Hunger et al., 2009). If other protocols are employed within a country, they can easily be incorporated into the forecasting model. The goal of the UN World Populations Prospects is to provide accurate and timely population data for all countries (United Nations, 2019). WHO and CDC growth charts can be used for any country-specific initial forecasts (Centers for Disease Control and Prevention, 2010). If a country has its own national growth charts, they can be utilized within the forecasting model to make it even more accurate. This may be especially relevant in countries where the average height of the population differs significantly from the CDC and WHO standards or where obesity is especially prevalent or especially rare.

\section{Weaknesses of Study}

The forecasting model estimated essential chemotherapy needs based upon surrogate measures. ALL incidence, growth curves, and imputed percentages of each ALL risk group may have introduced error in the estimated essential chemotherapy forecasting. UN World Populations Prospects was based upon population estimates and projections rather than the actual population measurements from robust annual census programs, which may have introduced an additional degree of error (United Nations, 2019). However, every surrogate measure can be appropriately adjusted if and when differences become known, such as right after a recent census shows that projections from a census 10 or 20 years earlier were off by a significant amount. Although ALL incidence rates and risk groups did not vary widely, the rate of non-diagnosis was highly correlated with poverty and lack of medical infrastructure (Katz et al., 2015). This can be 
addressed using estimates of non-diagnosis based on World Bank data and simulations, but such estimates do not account perfectly for non-diagnosis. The WHO and CDC growth curves are standardized and widely utilized. However, values for children in each country inevitably differ and can even vary by region or ethnic group within the same country. In addition to these expected variations, we suspected that the WHO and CDC growth curves for children in LMIC, in particular, may have overestimated chemotherapy needs (de Onis et al., 2010; Poskitt, 2014). For example, the WHO reported higher obesity among children in the US and more growthstunting in LMIC, which could lead to underestimation of chemotherapy needed for children in the US and overestimation for those in LMIC (World Health Organization, 2018). Where agespecific differences are known, the model could be refined. However, note that because most doses of essential chemotherapeutic agents were calculated based on body surface area rather than weight, the increase in dose varied with the square root of the increase in weight, so a child who weighs $100 \%$ more than mean weight for age would require only $41 \%$ more chemotherapy. In the end, the only way to definitively address all of the above weaknesses was to include all patients in a comprehensive information system that included a cancer registry; chemotherapy regimen used; and a roadmap with each drug and dose included, patient height and weight, and patient outcomes that would preclude further therapy on the initial regimen, such as relapse, death, or abandonment.

\section{Implications for Practice}

Our forecasting model and multipliers can equip healthcare providers with information that enables them to work to ensure their patients have access to essential chemotherapy. Healthcare providers can utilize the multipliers to rapidly estimate the annual essential chemotherapy needed for their treatment center or for an individual child. The multipliers enable health care providers to continuously and appropriately adjust the required inventory levels of essential chemotherapy based upon the number of ALL patients actively being treated within the treatment center. Healthcare providers can then work within their treatment centers to ensure a process wherein appropriate inventory levels and storage requirements are met. Healthcare providers could accomplish this by partnering with treatment center administrators and appropriate staff to determine whether their facility has the capacity to maintain weekly, monthly, or quarterly inventory levels of essential chemotherapy. Healthcare providers could encourage appropriate amounts of weekly or monthly purchasing from multiple in-country sources to ensure redundancy sourcing in case one supplier is out of inventory.

\section{Implications for Policy}

The forecasting model is valuable to policy makers because it can estimate the amount of each essential chemotherapy agent required for people with ALL, and by extension, any other cancer included in the full forecasting model in the future. Policy makers can use this information to budget and secure the appropriate amount of essential chemotherapy within their country, region, city, or facility. Healthcare providers could partner with policy makers to ensure their country has a national Essential Medicines List (EML) that is updated every 2 years and contains all essential chemotherapy listed on the WHO's list of essential medications. This is 
recognized as an important step for procurement and availability of essential chemotherapy for LMIC (Barr \& Robertson, 2016). Maintaining in-country appropriate inventory levels from multiple sources could provide advanced warnings of shortages such that additional or alternative suppliers could be sourced to potentially prevent or mitigate shortages. Healthcare providers could help policy makers understand that maintaining appropriate inventory levels, regular buying patterns, and ensuring storage requirements have increased children's access to essential chemotherapy and reduced acquisition cost (Denburg et al., 2014; Moye-Holz et al., 2017). With this understanding, supply chain procedures can be put in place to ensure that a year's supply of the lower bound estimate of the 9 essential chemotherapy to treat ALL is maintained in-country by monthly ordering patterns from multiple sources. The lower bound multipliers could be utilized to establish the initial inventory levels.

\section{Future Directions}

The established multipliers for the SIOP Adapted ALL Regimen would benefit from being examined in three ways. First, one could investigate if the minimum and maximum multipliers are useful in determining in-country inventory levels and buying patterns. Second, one could examine if the maximum multipliers are useful in estimating the quantity utilized of the 9 essential chemotherapies for individual children who complete the SIOP Adapted ALL Regimen. Third, one could examine how the forecasting model and multipliers compare to actual patient-level data utilized in information systems like electronic medical records, registries, or research systems.

\section{Further Guidelines for Information Systems}

An information system that collects patient-level data could simultaneously create accurate forecasts and document episodes when patients lacked effective access to essential chemotherapy, which would serve as an early-warning system for drug shortages. Patient-level data allows forecasting at the individual level to assure an adequate supply for the specific patient, aggregated at the center level for use by the hospital pharmacy, and rolled up to regional and national forecasts for bulk purchasing and to facilitate procurement of adequate supplies. An information system allows documentation and appropriate adjustment to chemotherapy forecasting based upon refusal, toxic death, abandonment, and excess relapse rates.

A forecast based on patient-level information can inform governmental agencies charged with provision of a continuous supply of essential medicines and can help prevent future shortages by assuring that a 12-month supply is on hand at all times so that if a supplier leaves the market, there will be ample time to identify and onboard another. It can also be linked to health insurance coverage to assure that it corresponds to patients' needs. Most importantly, patient-level information also includes patient outcomes and can be used to improve the quality of care in real time by addressing not only drug shortages but also diagnostic delay, abandonment, toxic death, and other causes of preventable treatment failure. This approach requires robust, integrated information systems and nuanced application of national funding mechanisms. 


\section{Conclusion}

More work is needed, but ALL can be cured with high-frequency and low-cost essential chemotherapy. Assuring an uninterrupted supply of essential chemotherapy is both critical and feasible. Age-standardized incidence rates, growth curves, and imputed risk stratification enable forecasting by cancer type, chemotherapy agent, and at any level of society (individual, hospital, city, state, nation, world). Such models can inform health policy and eliminate needless deaths from curable cancers due to unavailability of low-cost, essential drugs and other resources. Forecasting the maximum national needs for chemotherapeutic agents is feasible using existing public data sources. Multipliers may be useful in rapidly determining in-country and cancer treatment initial inventory levels and buying patterns. However, in-country patient-level information that includes refusal, abandonment, toxic death, and relapse is needed to estimate needs more precisely and improve all aspects of care. 


\section{LIST OF REFERENCES}

Allemani, C., Matsuda, T., Di Carlo, V., Harewood, R., Matz, M., Niksic, M., .. Coleman, M. P. (2018). Global surveillance of trends in cancer survival 2000-14 (CONCORD-3): analysis of individual records for 37513025 patients diagnosed with one of 18 cancers from 322 population-based registries in 71 countries. Lancet, 391(10125), 1023-1075. https://doi.org/10.1016/S0140-6736(17)33326-3

Allemani, C., Weir, H. K., Carreira, H., Harewood, R., Spika, D., Wang, X. S., . . Coleman, M. P. (2015). Global surveillance of cancer survival 1995-2009: analysis of individual data for 25,676,887 patients from 279 population-based registries in 67 countries (CONCORD-2). Lancet, 385(9972), 977-1010. https://doi.org/10.1016/S01406736(14)62038-9

Barr, R., \& Robertson, J. (2016). Access to Cytotoxic Medicines by Children With Cancer: A Focus on Low and Middle Income Countries. Pediatr Blood Cancer, 63(2), 287-291. https://doi.org/10.1002/pbc.25722

Bhakta, N., Martiniuk, A. L., Gupta, S., \& Howard, S. C. (2013). The cost effectiveness of treating paediatric cancer in low-income and middle-income countries: a case-study approach using acute lymphocytic leukaemia in Brazil and Burkitt lymphoma in Malawi. Arch Dis Child, 98(2), 155-160. https://doi.org/10.1136/archdischild-2011-301419

Centers for Disease Control and Prevention. (2010). WHO Growth Standards Are Recommended for Use in the U.S. for Infants and Children 0 to 2 Years of Age. Retrieved from http://www.cdc.gov/growthcharts/who charts.htm\#The $\% 20$ WHO $\% 20$ Growth $\% 20$ Charts

Cooper, S. L., \& Brown, P. A. (2015). Treatment of Pediatric Acute Lymphoblastic Leukemia. Pediatr Clin North Am, 62(1), 61-73. https://doi.org/10.1016/j.pcl.2014.09.006

de Onis, M., Blossner, M., \& Borghi, E. (2010). Global prevalence and trends of overweight and obesity among preschool children. Am J Clin Nutr, 92(5), 1257-1264. https://doi.org/10.1093/ajen/72.4.1032

Denburg, A. E., Knaul, F. M., Atun, R., Frazier, L. A., \& Barr, R. D. (2014). Beyond the bench and the bedside: economic and health systems dimensions of global childhood cancer outcomes. Pediatr Blood Cancer, 61(3), 572-576. https://doi.org/10.1002/pbc.24858

Electronic Medicines Compendium. (n.d.). Latest Medicine Updates. Retrieved from https://www.medicines.org.uk/emc/

Essig, S., Li, Q., Chen, Y., Hitzler, J., Leisenring, W., Greenberg, M., .. . Nathan, P. C. (2014). Risk of late effects of treatment in children newly diagnosed with standard-risk acute lymphoblastic leukaemia: a report from the Childhood Cancer Survivor Study cohort. Lancet Oncol, 15(8), 841-851. https://doi.org/10.1016/S1470-2045(14)70265-7.

Fisher, D., Wicks, P., \& Babar, Z. U. (2016). Medicine and the future of health: reflecting on the past to forge ahead. BMC Med, 14(1), 169. https://doi.org/10.1186/s12916-016-0717-0

Gaynon, P. S. (2017). Mercaptopurine in childhood acute lymphoblastic leukaemia. Lancet Oncol, 18(4), 425-426. https://doi.org/10.1016/S1470-2045(17)30152-3

Gray, A., \& Manasse, H. R., Jr. (2012). Shortages of medicines: a complex global challenge. Bull World Health Organ, 90(3), 158-158a. https://doi.org/10.2471/BLT.11.101303

Groves, F. D. (2017). Inverse Correlation of Lymphoid Leukemia Incidence and Anemia Prevalence among Preschool Children. South Med J, 110(5), 337-342. https://doi.org/10.14423/SMJ.0000000000000647 
Howard, S. C., Davidson, A., Luna-Fineman, S., Israels, T., Chantada, G., Lam, C. G., . . . Metzger, M. L. (2017). A framework to develop adapted treatment regimens to manage pediatric cancer in low- and middle-income countries: The Pediatric Oncology in Developing Countries (PODC) Committee of the International Pediatric Oncology Society (SIOP). Pediatr Blood Cancer, 64 Suppl 5. https://doi.org/10.1002/pbc.26879

Howard, S. C., Marinoni, M., Castillo, L., Bonilla, M., Tognoni, G., Luna-Fineman, S., . . . Masera, G. (2007). Improving outcomes for children with cancer in low-income countries in Latin America: a report on the recent meetings of the Monza International School of Pediatric Hematology/Oncology (MISPHO)-Part I. Pediatr Blood Cancer, 48(3), 364369. https://doi.org/10.1002/pbc.21003

Howard, S. C., Metzger, M. L., Wilimas, J. A., Quintana, Y., Pui, C. H., Robison, L. L., \& Ribeiro, R. C. (2008). Childhood cancer epidemiology in low-income countries. Cancer, 112(3), 461-472. https://doi.org/10.1002/cncr.23205

Hsu, S. C., Metzger, M. L., Hudson, M. M., Pedrosa, F., Lins, M., Pedrosa, M., . . Howard, S. C. (2007). Comparison of treatment outcomes of childhood Hodgkin lymphoma in two US centers and a center in Recife, Brazil. Pediatr Blood Cancer, 49(2), 139-144. https://doi.org/10.1002/pbc. 20883

Hunger, S. P., Sung, L., \& Howard, S. C. (2009). Treatment strategies and regimens of graduated intensity for childhood acute lymphoblastic leukemia in low-income countries: A proposal. Pediatr Blood Cancer, 52(5), 559-565. https://doi.org/10.1002/pbc.21889

Iyengar, S., Hedman, L., Forte, G., \& Hill, S. (2016). Medicine shortages: a commentary on causes and mitigation strategies. BMC Med, 14(1), 124. https://doi.org/10.1186/s12916$\underline{\text { 016-0674-7 }}$

Jabbour, E., Pui, C. H., \& Kantarjian, H. (2018). Progress and Innovations in the Management of Adult Acute Lymphoblastic Leukemia. JAMA Oncol. https://doi.org/10.1001/jamaoncol.2018.1915

Jaime-Perez, J. C., Lopez-Razo, O. N., Garcia-Arellano, G., Pinzon-Uresti, M. A., JimenezCastillo, R. A., Gonzalez-Llano, O., \& Gomez-Almaguer, D. (2016). Results of Treating Childhood Acute Lymphoblastic Leukemia in a Low-middle Income Country: 10 Year Experience in Northeast Mexico. Arch Med Res, 47(8), 668-676. https://doi.org/10.1016/j.arcmed.2017.01.004

Jeha, S., Pei, D., Choi, J., Cheng, C., Sandlund, J. T., Coustan-Smith, E., . . Pui, C. H. (2019). Improved CNS Control of Childhood Acute Lymphoblastic Leukemia Without Cranial Irradiation: St Jude Total Therapy Study 16. J Clin Oncol, 37(35), 3377-3391. https://doi.org/10.1200/jco.19.01692

Katz, A. J., Chia, V. M., Schoonen, W. M., \& Kelsh, M. A. (2015). Acute lymphoblastic leukemia: an assessment of international incidence, survival, and disease burden. Cancer Causes Control, 26(11), 1627-1642. https://doi.org/10.1007/s10552-015-0657-6

Lam, C. G., Howard, S. C., Bouffet, E., \& Pritchard-Jones, K. (2019). Science and health for all children with cancer. Science, 363(6432), 1182-1186. https://doi.org/10.1126/science.aaw4892

Magrath, I., Steliarova-Foucher, E., Epelman, S., Ribeiro, R. C., Harif, M., Li, C. K., .. . Howard, S. C. (2013). Paediatric cancer in low-income and middle-income countries. Lancet Oncol, 14(3), e104-116. https://doi.org/10.1016/S1470-2045(13)70008-1

Mehta, P. S., Wiernikowski, J. T., Petrilli, J. A., Barr, R. D., \& Working Group on Essential Medicines of the Pediatric Oncology in Developing Countries committee of SIOP. 
(2013). Essential medicines for pediatric oncology in developing countries. Pediatr Blood Cancer, 60(5), 889-891. https://doi.org/10.1002/pbc.24476

Moricke, A., Zimmermann, M., Reiter, A., Henze, G., Schrauder, A., Gadner, H., . . . Schrappe, M. (2010). Long-term results of five consecutive trials in childhood acute lymphoblastic leukemia performed by the ALL-BFM study group from 1981 to 2000. Leukemia, 24(2), 265-284. https://doi.org/10.1038/leu.2009.257

Moye-Holz, D., van Dijk, J. P., Reijneveld, S. A., \& Hogerzeil, H. V. (2017). Policy approaches to improve availability and affordability of medicines in Mexico - an example of a middle income country. Global Health, 13(1), 53. https://doi.org/10.1186/s12992-017-0281-1

National Cancer Institute, N. (2018). General Information About Childhood Acute Lymphoblastic Leukemia. Retrieved from https://www.cancer.gov/types/leukemia/patient/child-all-treatment-pdq

National Institutes of Health. (2010). National Institutes of Health National Cancer Institute Surveillance, Epidemiology, and End Results. Retrieved from https://seer.cancer.gov/archive/csr/1975 2010/browse csr.php?sectionSEL=28\&pageSE $\underline{\mathrm{L}}=$ sect 28 table. 13 .html

PhilHealth. (2018). PhilHelath Your Partner in Health. Retrieved from https://www.philhealth.gov.ph/benefits/

Philippine Statistics Authority. (2017). Philippine Population Surpassed the 100 Million Mark (Results from the 2015 Census of Population). Retrieved from https://www.psa.gov.ph/content/philippine-population-surpassed-100-million-markresults-2015-census-population

Pisa, M., \& McCurdy, D. (2019). Improving Global Health Supply Chains through Traceability. Retrieved from https://www.cgdev.org/publication/improving-global-health-supplychains-through-traceability

Poskitt, E. M. (2014). Childhood obesity in low- and middle-income countries. Paediatr Int Child Health, 34(4), 239-249. https://doi.org/10.1179/2046905514y.0000000147

Pribnow, A. K., Ortiz, R., Baez, L. F., Mendieta, L., \& Luna-Fineman, S. (2017). Effects of malnutrition on treatment-related morbidity and survival of children with cancer in Nicaragua. Pediatr Blood Cancer, 64(11). https://doi.org/10.1002/pbc.26590

Pritchard-Jones, K., Pieters, R., Reaman, G. H., Hjorth, L., Downie, P., Calaminus, G., . . . Steliarova-Foucher, E. (2013). Sustaining innovation and improvement in the treatment of childhood cancer: lessons from high-income countries. Lancet Oncol, 14(3), e95-e103. https://doi.org/10.1016/s1470-2045(13)70010-x

Redaniel, M. T., Laudico, A., Mirasol-Lumague, M. R., Alcasabas, A. P., Pulte, D., \& Brenner, H. (2010). Geographic and ethnic differences in childhood leukaemia and lymphoma survival: comparisons of Philippine residents, Asian Americans and Caucasians in the United States. Br J Cancer, 103(1), 149-154. https://doi.org/10.1038/sj.bjc.6605703

Rodriguez-Galindo, C., Friedrich, P., Alcasabas, P., Antillon, F., Banavali, S., Castillo, L., . . . Gross, T. (2015). Toward the Cure of All Children With Cancer Through Collaborative Efforts: Pediatric Oncology As a Global Challenge. J Clin Oncol, 33(27), 3065-3073. https://doi.org/10.1200/jco.2014.60.6376

Ruff, P., Al-Sukhun, S., Blanchard, C., \& Shulman, L. N. (2016). Access to Cancer Therapeutics in Low- and Middle-Income Countries. Am Soc Clin Oncol Educ Book, 35, 58-65. https://doi.org/10.14694/edbk 155975 
Siegel, D. A., Henley SJ, Li J, Pollack LA, Van Dyne EA, \& A, W. (2017). Rates and Trends of Pediatric Acute Lymphoblastic Leukemia — United States, 2001-2014. Retrieved from https://www.cdc.gov/mmwr/volumes/66/wr/mm6636a3.htm\#T1 down

Simonyan, T., Papyan, R., Danielyan, S., Sargsyan, L., Grigoryan, V., Topchyan, H., . . . Tamamyan, G. (2019). Availability of Essential Medicines for Pediatric Oncology in Armenia. Asian Pac J Cancer Prev, 20(4), 991-994. https://doi.org/10.31557/apjcp.2019.20.4.991

Singh, M., Bhatia, P., Khera, S., \& Trehan, A. (2017). Emerging role of NUDT15 polymorphisms in 6-mercaptopurine metabolism and dose related toxicity in acute lymphoblastic leukaemia. Leuk Res, 62, 17-22. https://doi.org/10.1016/j.leukres.2017.09.012

Smid, A., Karas-Kuzelicki, N., Jazbec, J., \& Mlinaric-Rascan, I. (2016). PACSIN2 polymorphism is associated with thiopurine-induced hematological toxicity in children with acute lymphoblastic leukaemia undergoing maintenance therapy. Sci Rep, 6, 30244. https://doi.org/10.1038/srep30244

United Nations. (2019). World Population Prospects Retrieved from https://population.un.org/wpp/Download/Standard/Population/

United States Food \& Drug Administration. (2018). Drugs@FDA: FDA-Approved Drugs. Retrieved from https://www.accessdata.fda.gov/scripts/cder/daf/

United States Food and Drug Administration. (2013). Strategic plan for preventing and mitigating drug shortages food and drug administration Retrieved from https://www.fda.gov/downloads/Drugs/DrugSafety/DrugShortages/UCM372566.pdf

World Bank. (2018). New country classifications by income level: 2018-2019. Retrieved from https://datahelpdesk.worldbank.org/knowledgebase/articles/906519-world-bank-countryand-lending-groups

World Health Organization. (2018). Global Database on Child Growth and Malnutrition. Retrieved from http://www.who.int/nutgrowthdb/estimates2017/en/

World Health Organization. (2019). WHO Model Lists of Essential Medicines. Retrieved from https://www.who.int/medicines/publications/essentialmedicines/en/

World Heath Organization. (2016). Global approaches to addressing shortages of essential medicines in health systems. Retrieved from https://www.who.int/medicines/publications/druginformation/WHO_DI 302_Medicines.pdf?ua $=1$ 


\section{APPENDIX. STANDARD POPULATION-BASED MULTIPLIER FOR EACH ESSENTIAL CHEMOTHERAPY}

Table A-1. Standard population-based multiplier for SIOP Adapted ALL Regimen Level 1 without cranial radiation in three countries

\begin{tabular}{|c|c|c|c|c|c|}
\hline Variable & Tanzania & Honduras & Venezuela & Average & Multiplier \\
\hline $\begin{array}{l}\text { Number of children } \\
\text { (age } 0 \text { to } 19 \text { years) }\end{array}$ & $32,451,358$ & $4,070,625$ & $10,253,167$ & $46,775,150$ & \\
\hline $\begin{array}{l}\text { Estimated children } \\
\text { with acute } \\
\text { lymphoblastic } \\
\text { leukemia each year }\end{array}$ & 1,236 & 144 & 356 & 1,736 & \\
\hline $\begin{array}{l}\text { Prednisone/patient } \\
\text { (rounded) }\end{array}$ & 1,140 & 1,140 & 1,140 & 1,140 & \\
\hline $\begin{array}{l}\text { Prednisone }(\mathrm{mg}) \text { per } \\
\text { country per year }\end{array}$ & $1,409,040$ & 164,160 & 405,840 & $1,979,040$ & Prednisone \\
\hline $\begin{array}{l}\text { Population multiplier } \\
\text { (mg of prednisone per } \\
\text { child per year) }\end{array}$ & 0 & 0 & 0 & 0 & 0.0411 \\
\hline $\begin{array}{l}\text { Vincristine/patient } \\
\text { (rounded) }\end{array}$ & 46 & 46 & 46 & 46 & \\
\hline $\begin{array}{l}\text { Vincristine }(\mathrm{mg}) \text { per } \\
\text { country per year }\end{array}$ & 56,856 & 6,624 & 16,376 & 79,856 & Vincristine \\
\hline $\begin{array}{l}\text { Vincristine multiplier } \\
\text { (mg of } \\
\text { mercaptopurine per } \\
\text { child per year) }\end{array}$ & 0 & 0 & 0 & 0 & 0.0017 \\
\hline $\begin{array}{l}\text { L-asparaginase/patient } \\
\text { (rounded) }\end{array}$ & 47,336 & 47,336 & 47,336 & 47,336 & \\
\hline $\begin{array}{l}\text { L-asparaginase (units) } \\
\text { per country per year }\end{array}$ & $58,507,296$ & $6,816,384$ & $16,851,616$ & $82,175,296$ & L-asparaginase \\
\hline
\end{tabular}


Table A-1. (Continued)

\begin{tabular}{|c|c|c|c|c|c|}
\hline Variable & Tanzania & Honduras & Venezuela & Average & Multiplier \\
\hline $\begin{array}{l}\text { Population multiplier } \\
\text { (units of L- } \\
\text { asparaginase per child } \\
\text { per year) }\end{array}$ & 0 & 0 & 0 & 0 & 1.7070 \\
\hline $\begin{array}{l}\text { Intrathecal } \\
\text { methotrexate/patient } \\
\text { (rounded) }\end{array}$ & 240 & 240 & 240 & 240 & \\
\hline $\begin{array}{l}\text { Intrathecal } \\
\text { methotrexate (mg) per } \\
\text { country per year }\end{array}$ & 296,640 & 34,560 & 85,440 & 416,640 & $\begin{array}{c}\text { Methotrexate, } \\
\text { intrathecal }\end{array}$ \\
\hline $\begin{array}{l}\text { Population multiplier } \\
\text { (mg of Intrathecal } \\
\text { methotrexate per child } \\
\text { per year) }\end{array}$ & 0 & 0 & 0 & 0 & 0.0087 \\
\hline $\begin{array}{l}\text { Oral } \\
\text { methotrexate/patient } \\
\text { (rounded) }\end{array}$ & 1,858 & 1,858 & 1,858 & 1,858 & \\
\hline $\begin{array}{l}\text { Oral methotrexate } \\
(\mathrm{mg}) \text { per country per } \\
\text { year }\end{array}$ & $2,296,488$ & 267,552 & 661,448 & $3,225,488$ & $\begin{array}{c}\text { Methotrexate, } \\
\text { oral }\end{array}$ \\
\hline $\begin{array}{l}\text { Population multiplier } \\
\text { (mg of oral } \\
\text { methotrexate per child } \\
\text { per year) }\end{array}$ & 0 & 0 & 0 & 0 & 0.0670 \\
\hline $\begin{array}{l}\text { Number of children } \\
\text { (age } 0 \text { to } 19 \text { years) }\end{array}$ & $32,451,358$ & $4,070,625$ & $10,253,167$ & $46,775,150$ & \\
\hline $\begin{array}{l}\text { Intravenous } \\
\text { methotrexate/patient } \\
\text { (rounded) }\end{array}$ & 0 & 0 & 0 & 0 & \\
\hline $\begin{array}{l}\text { Intravenous } \\
\text { methotrexate }(\mathrm{mg}) \text { per } \\
\text { country per year }\end{array}$ & 0 & 0 & 0 & 0 & $\begin{array}{c}\text { Methotrexate, } \\
\text { intravenous }\end{array}$ \\
\hline
\end{tabular}


Table A-1. $\quad$ (Continued)

\begin{tabular}{|c|c|c|c|c|c|}
\hline Variable & Tanzania & Honduras & Venezuela & Average & Multiplier \\
\hline $\begin{array}{l}\text { Population multiplier (mg } \\
\text { of intravenous } \\
\text { methotrexate per child per } \\
\text { year) }\end{array}$ & 0 & 0 & 0 & 0 & 0.0000 \\
\hline $\begin{array}{l}\text { Dexamethasone/patient } \\
\text { (rounded) }\end{array}$ & 789 & 789 & 789 & 789 & \\
\hline $\begin{array}{l}\text { Dexamethasone }(\mathrm{mg}) \text { per } \\
\text { country per year }\end{array}$ & 975,204 & 113,616 & 280,884 & $1,369,704$ & Dexamethasone \\
\hline $\begin{array}{l}\text { Population multiplier (mg } \\
\text { of dexamethasone per } \\
\text { child per year) }\end{array}$ & 0 & 0 & 0 & 0 & 0.0285 \\
\hline $\begin{array}{l}\text { Mercaptopurine/patient } \\
\text { (rounded) }\end{array}$ & 57,067 & 57,067 & 57,067 & 57,067 & \\
\hline $\begin{array}{l}\text { Mercaptopurine (mg) per } \\
\text { country per year }\end{array}$ & $70,534,812$ & $8,217,648$ & $20,315,852$ & $99,068,312$ & Mercaptopurine \\
\hline $\begin{array}{l}\text { Population multiplier (mg } \\
\text { of mercaptopurine per } \\
\text { child per year) }\end{array}$ & 0 & 0 & 0 & 0 & 2.0579 \\
\hline $\begin{array}{l}\text { Doxorubicin/patient } \\
\text { (rounded) }\end{array}$ & 0 & 0 & 0 & 0 & \\
\hline $\begin{array}{l}\text { Doxorubicin }(\mathrm{mg}) \text { per } \\
\text { country per year }\end{array}$ & 0 & 0 & 0 & 0 & Doxorubicin \\
\hline $\begin{array}{l}\text { Population multiplier (mg } \\
\text { of doxorubicin per child } \\
\text { per year) }\end{array}$ & 0 & 0 & 0 & 0 & 0.0000 \\
\hline $\begin{array}{l}\text { Cyclophosphamide/patient } \\
\text { (rounded) }\end{array}$ & 0 & 0 & 0 & 0 & \\
\hline $\begin{array}{l}\text { Cyclophosphamide (mg) } \\
\text { per country per year }\end{array}$ & 0 & 0 & 0 & 0 & Cyclophosphamide \\
\hline
\end{tabular}




\section{Table A-1. (Continued)}

\begin{tabular}{lccccc}
\hline Variable & Tanzania & Honduras & Venezuela & Average & Multiplier \\
\hline $\begin{array}{l}\text { Population multiplier } \\
\text { (mg of }\end{array}$ & 0 & 0 & 0 & 0 & 0.0000 \\
$\begin{array}{l}\text { cyclophosphamide } \\
\text { per child per year) }\end{array}$ & & & & & \\
$\begin{array}{l}\text { Cytarabine/patient } \\
\text { (rounded) }\end{array}$ & 0 & 0 & 0 & 0 & \\
$\begin{array}{l}\text { Cytarabine (mg) per } \\
\text { country per year }\end{array}$ & 0 & 0 & 0 & 0 & Cytarabine \\
$\begin{array}{l}\text { Number of children } \\
\text { (age 0 to 19 years) }\end{array}$ & $32,451,358$ & $4,070,625$ & $10,253,167$ & $46,775,150$ & \\
$\begin{array}{l}\text { Population multiplier } \\
\text { (mg of cytarabine per } \\
\text { child per year) }\end{array}$ & 0 & 0 & & & \\
\hline
\end{tabular}

Note: $\mathrm{mg}$ - Milligrams 


\section{VITA}

Brian T. Lewis was born in Hutchinson, Kansas in 1968. He has received undergraduate degrees in Philosophy and Nursing and a Master's of Nursing Administration from the University of Memphis.

Brian has worked clinically as a nurse in telemetry, cardiovascular critical care, and surgery. Brian has also worked in the pharmaceutical industry as a specialty and hospital representative. He has also participated in corporate rotation assignments in the pharmaceutical industry in speaker training, customer focus groups, training, and marketing. Brian has also served in leadership capacity as an executive business manager. Brian received his Doctor of Philosophy degree in Nursing Science in May of 2020. 